\title{
AMADORES DAARTE: \\ Práticas artísticas em cursos livres de pintura da cidade de São Paulo
}

\author{
Tese apresentada à Faculdade de Educação \\ da Universidade de São Paulo para obtenção \\ do título de Doutor em Educação. Linha de \\ pesquisa Linguagem e Educação. Orientador \\ Prof. Dr. Celso Fernando Favaretto
}


AUTORIZO A REPRODUÇÃO E DIVULGAÇÃO TOTAL OU PARCIAL DESTE TRABALHO, SEM FINALIDADE COMERCIAL, POR QUALQUER MEIO CONVENCIONAL OU ELETRÔNICO, PARA FINS DE ESTUDO E PESQUISA, DESDE QUE CITADAAFONTE. 


\section{Luciana Mourão Arslan}

Amadores da arte: Práticas artísticas

em cursos livres de pintura da cidade de São Paulo

Tese apresentada à Faculdade de Educação da Universidade de São Paulo para obtenção do título de Doutor em Educação Linha de pesquisa Linguagem e Educação

Aprovado em:

\section{Banca examinadora}

Membros titulares:

Orientador: Celso Fernando Favaretto Instituição: FE - USP Dpto: EDM

Titulação: Livre-docente

Assinatura:

Profa. Dra. Maria da Graça Setton

Instituição: FE - USP Dpto: EDF

Titulação: Doutora

Assinatura:

Profa. Dra. Rosa Iavelberg

Instituição: FE - USP Dpto: EDM

Titulação: Doutora

Assinatura:

Profa. Dra. Maria Lúcia Bueno

Instituição: Centro Universitário SENAC

Dpto: Pós-Graduação

Titulação: Doutora

Assinatura:

Profa. Dr. José Guilherme Magnani

Instituição: FFLCH - USP

Dpto: Antropologia

Titulação: Doutor

Assinatura:

\section{Membros suplentes:}

Prof. Dr. Afrânio Mendes Catani Instituição: FE - USP Dpto: EDA

Titulação: Livre-docente

Assinatura:

Prof. Dr. Ricardo Nascimento Fabbrini Instituição: PUC - SP

Dpto: Pós-Graduação - Filosofia Titulação: Doutor

Assinatura: 



\section{AGRADECIMENTOS}

Ressalto a admiração por muitos professores da Faculdade de Educação da Universidade de São Paulo, que se dedicam sobremaneira à orientação de pesquisadores: Cláudia Pereira Vianna, Maria da Graça Setton, Rosa Iavelberg, são alguns com os quais aprendi diferentes aspectos da vida universitária.

Também agradeço a Fernando Hernández, por ter me dado a oportunidade de participar dos grupos de estudos na Faculdade de Belas Artes da Universidade de Barcelona. Meu estágio nessa cidade também contou com o apoio da bolsa de mobilidade internacional oferecida pelo Banco Santander em parceria com a Universidade de São Paulo. Graças a eles, e ao apoio do meu orientador, experimentei, por seis meses, o gosto de "apenas" estudar.

Agradeço ao meu pai pelo apoio e à minha mãe por tantas vezes revisar o texto comigo, com doces tentativas de correção da minha escrita. Amigos e colegas também cooperaram com este trabalho, sugerindo idéias, emprestando livros ou ajudando em problemas práticos, como diagramação e impressão, escutando o choro desgostoso e as reclamações, aconselhando a não desistir; e assim, direta e indiretamente, devo-lhes agradecimentos: Beatriz Rudge, Gazy Andraus, Gilberto Habib, Kátia Bastos, Maria Lúcia Montes, Márcia ReginaAlvarenga, Roberta Rosa e a todos os entrevistados que participam deste trabalho.

Ao meu orientador, que me acompanhou por quatro anos, só posso dizer que o nosso convívio certamente me ensinou coisas para além da tese apresentada, e que a linguagem escrita, ou a palavra, podem só parcialmente representar o tempo e a experiência vivenciados. 



\title{
RESUMO
}

Esta pesquisa investiga práticas artísticas em alguns cursos livres de pintura da cidade de São Paulo. Gostos e idéias sobre arte muito heterogêneos surgem nestes espaços informais de ensino. Este trabalho se propõe a identificar essa diversidade e interpretar as concepções e funções de arte que presidem distintas formas de práticas artísticas vigentes não institucionalizadas na cidade de São Paulo.

Palavras-chave: multiculturalidade; concepções de arte; práticas culturais; amadores.

\begin{abstract}
This research analyses artistic practices in painting courses provided by organisations which are not linked to official educational bodies in São Paulo. Many different and heterogeneous tastes and ideas arise in these informal teaching spaces. The purpose of this research is to identify the diversity and interpret the concepts and functions of art used in the artistic practices in these less formal organisations.
\end{abstract}

Key-words: multiculturalism, art concepts, cultural practices, art amateurs. 



\section{LISTA DE ILUSTRAÇÕES}

MAPA 1: Localização da amostra dos cursos de pintura da região do centro expandido de São Paulo

Figura 1: Prospecto Universidade Livre de Arte - ULA

Figura 2: Detalhe da Revista Arte em Tela

Figura 3: Prospecto do ateliê ICCLA

NARRATIVA VISUAL 1: Cursos de pintura em escolas de grande porte

NARRATIVA VISUAL 2 : Cursos de pintura oferecidos nos ateliês dos artistas

NARRATIVA VISUAL 3: Escolas de pequeno porte

NARRATIVA VISUAL 4: Cursos em casa

NARRATIVA VISUAL 5 : Percurso de uma aluna que faz arte como conhecimento

TABELA 1: Roteiro base para as entrevistas 50

TABELA 2: Reproduções de obras utilizadas nas entrevistas

TABELA 3: Cursos livres na Cidade de São Paulo

TABELA 4: Relação dos alunos por tipo de concepção predominante de arte

TABELA 5: Arte como expressão

TABELA 6: Arte como fazer

TABELA 7: Arte como conhecimento 



\section{LISTA DE APÊNDICES}

APÊNDICE A: Diário da tese 



\section{SUMÁRIO}

INTRODUÇÃO

\section{CAPITULO 1}

1. Amadores da arte: Uma aproximação a partir de Bourdieu,

Canclini, M. de Certeau e dos Estudos de Cultura Visual 33

1.1 A contribuição de Pierre Bourdieu

1.2 Canclini e de Certeau: práticas e táticas culturais

1.3 Estudos de Cultura Visual: um modo de operar

1.4 O campo da Cultura Visual e a suspensão da idéia de arte

1.5 Sobre o trabalho etnográfico e as entrevistas com os freqüentadores de cursos livres

ESCRITOS DO MEIO II - Do desgosto

\section{CAPÍTULO 2}

2. Caracterização Geral dos Cursos Livres

2.1 Primeiro Cenário: As escolas de grande porte

2.2. Segundo Cenário: Cursos de pintura oferecidos em ateliês

de artistas

2.3 Terceiro Cenário: Os ateliês coletivos/escolas

2.4 Quarto Cenário: Cursos em escolas de pequeno porte

2.5 Quinto Cenário: Cursos de pintura ministrados na casa dos professores

2.6 Considerações sobre os diversos cenários - escolas de pintura 100

2.7 Formação dos professores dos cursos livres de pintura 



\section{CAPÍtULLO 3}

3. Libidos artísticas

3.1. Táticas contra uma relação distanciada com a arte: arte como expressão (ou manifestação dos sentimentos) e arte como técnica (ou como fazer)

3.1.1 Arte como expressão dos sentimentos

3.1.2 Arte como fazer

3.2. Arte como conhecimento: $O$ distanciamento estético

ESCRITOS DO MEIO IV - Instalações de arte, dança do ventre e música evangélica

CONCLUSÃO 
INTRODUÇÃO 


\section{Introdução}

A arte é transmitida em instituições formais e não-formais: como disciplina obrigatória no ensino da escola básica, em museus, ateliês de artistas, escolas livres de arte, universidades, publicações, cursos via Internet ou vídeo, entre outros. O ensino de arte hoje é oferecido tanto a profissionais quanto a amadores, pode ser público ou privado, em grupo ou individual.

A pintura, ao lado da fotografia do cinema e das histórias em quadrinhos, é possivelmente a mais freqüente e difundida linguagem visual. Na cidade de São Paulo, os cursos livres ${ }^{1}$ de pintura são atrativos; numerosos, alguns destes cursos acontecem à margem do ensino formal, seja da escola básica ou da universidade. Com base nisso, poder-se-ia supor que a arte é acessível a todos. Mas que arte é acessível a todos? Uma única concepção de arte permeia todos estes locais e suas práticas? Mesmo compartilhando uma mesma concepção de arte, podemos indagar ainda se a forma de se relacionar com esta arte acontece de forma semelhante.

Os cursos de pintura, oferecidos em locais variados ${ }^{2}$, são freqüentados por alunos com interesses diferentes e objetivos e disposições dispares em relação à aprendizagem em arte: pintar por hobby, como terapia, forma de enriquecimento cultural, de profissionalização entre outros.

Palavras como "globalização da arte" ou "arte pública" viraram chavões que, ao referirem a arte como "democratizada", encobrem o sentido de que a arte, ou o sentido de se relacionar com a arte, é de uma ordem determinada, estrita. Entretanto, muitas formas de se relacionar com arte são ignoradas por simplesmente não serem "legíveis".

\footnotetext{
${ }^{1}$ Chamamos estes cursos de cursos "livres" por acontecerem fora do âmbito acadêmico.
} 
Existe muita incompreensão dessas práticas, mesmo quando analisadas sob o ponto de vista da teoria de Pierre Bourdieu² sobre o campo de produção cultural, para quem, como se sabe, a eficácia de uma determinada produção cultural depende de um conjunto orquestrado de interesses e formas preexistentes. Ou seja, a compreensão e a legitimação das produções culturais dependem deste ajustamento combinado no campo cultural; do contrário, são simplesmente incompreensíveis.

Entender práticas artísticas desajustadas pressupõe aceitar diferentes concepções de arte, suas relações e transformações na relação com outras práticas como, por exemplo, o lazer e o turismo. As práticas, segundo Shusterman, podem ser compreendidas como atividade agregadora de razões internas e externas ${ }^{3}$. Segundo Dumazedier ${ }^{4}$, a função do lazer para o desenvolvimento pessoal compreende uma diversidade de práticas culturais. Assim, nessa associação com o lazer, a arte congrega outros valores e passa a emprestar significados dessas outras práticas. Aliás, historicamente, a concepção de arte já teve, mesmo que sob outras denominações como téchné e poiésis, conexões com esporte e lazer ${ }^{5}$.

A análise das práticas artísticas dos alunos dos cursos livres de pintura convida à reflexão sobre a simultaneidade de diversas concepções, usos e funções da arte. Referirse genericamente a "público de arte" pode amalgamar formas distintas da noção de arte e de se relacionar com arte. Legítimas, reconhecidas ou não, diferentes práticas de fruir e fazer arte parecem coexistir na cidade de São Paulo. Assim, locais de exposições, como a feira de arte da Praça da República, o mercado de materiais didáticos para pintura a óleo, exposições em shopping centers ou ainda cursos de arte, podem esconder curiosos usos e funções da arte. Sem uma análise dessas práticas, não se pode afirmar a natureza do uso da arte nestes diferentes contextos: um aluno de pintura que é freqüentador da

\footnotetext{
${ }^{2}$ BOURDIEU, P. A produção da crença: contribuição para uma economia dos bens simbólicos. São Paulo: Zouk, 2002, p. 52-59.

${ }^{3}$ SHUSTERMAN, R. Vivendo a arte: O pensamento pragmatista e a estética popular. São Paulo: 34 Letras, 1998.

${ }^{4}$ DUMAZEDIER, J. Lazer e cultura popular. $3^{\mathrm{a}}$ ed. São Paulo: Perspectiva, 2004.

${ }^{5}$ SHUSTERMAN, R. op. cit., p. 31.
} 
Praça da República e um aluno do Museu de Arte Moderna hipoteticamente se diferenciam quanto a estes usos; mas que usos são estes? E fazem arte com qual objetivo?

A hipótese central deste trabalho é a de que muitos usos e funções da arte coexistem nos cursos de pintura, ativados por diferentes concepções de arte. Por serem, em sua maioria, cursos livres menos formais, acredita-se que neles encontre-se, de modo mais explícito, uma variedade de práticas pouco ou nada reguladas pelos sistemas de legitimação artístico-culturais. A circunscrição do imaginário cultural e a concepção que alunos dos cursos livres possuem de arte são uma forma de conhecer as práticas articuladas neles. A extensão da compreensão do que significa fazer arte na sociedade contemporânea se inicia no reconhecimento de práticas menores e ainda desconhecidas.

Pensar nestas diferentes disposições no relacionamento com arte, supõe discutir o assunto segundo alguns fundamentos da arte e das suas funções na vida cotidiana, incluindo a estetização que promove ${ }^{6}$. Também supõe utilizar procedimentos sociológicos para a identificação das características macro-sociais implicadas nas escolhas culturais; e, ademais, buscar a perspectiva de análise antropológica, já que isto implica os conceitos de imaginário e de hibridismo cultural ${ }^{7}$. Assim sendo, autores como Pierre Bourdieu, Michel de Certeau e Nestor Canclini, cujos trabalhos se situam no entrecruzamento de várias disciplinas, tornam-se relevantes para analisar as práticas culturais como as desta pesquisa.

Também no decorrer da pesquisa surgiu a necessidade de se recorrer aos estudos da Cultura Visual, tendo-se em vista o fato de oferecer, em alguns casos, novos caminhos para o entendimento das “visualidades" - práticas não definidas como artísticas. São referências metodológicas que podem contribuir para uma abordagem mais empírica das práticas cotidianas. Nas pesquisas deste campo emergem muitas teorias e análises que provêm de estudos etnográficos contemporâneos, como a autoetnografia. Segundo a

\footnotetext{
${ }^{6}$ A estética do cotidiano considera, além dos objetos e atividades que possuem valor estético dentro de uma cultura, "a subjetividade dos sujeitos que a compõem e cuja estética se organiza a partir de muitas facetas do seu processo de vida e de transformação". RICHTER, I. M. Interculturalidade e estética do cotidiano no ensino das artes visuais. Campinas: Mercado de Letras, 2003, p. 20-21. ${ }^{7}$ Cf. CANCLINI, N. G. Culturas hibridas: estratégias para entrar e sair da modernidade. São Paulo: Edusp, 2003.
} 
autoetnografia, a observação nunca é impessoal, pois é feita a partir do lugar do pesquisador: quem observa e faz a análise da reflexão sobre o outro, quem protagoniza qualquer pesquisa. Por isso, muitas investigações dessa área são escritas na primeira pessoa e situam o tempo todo o pesquisador como ator em interação com o cenário pesquisado. Foi a partir da autoetnografia que, durante a elaboração deste trabalho, fortificou-se uma idéia de criação autoral, pois se considera que o olhar do pesquisador, por mais informado etnograficamente que seja, está sempre impregnado de construções pessoais e subjetivas. Se, por um lado, perde-se a possibilidade de análise objetiva das entrevistas feitas com os alunos de pintura, e de suas práticas; por outro, adquiri-se maior compreensão sobre o processo de aprendizagem diante do observado, das estruturas que se despregam do lugar cultural do pesquisador-observador.

Parte da dificuldade deste trabalho, e de outros desta natureza, é que ele trata de um fazer que não é reconhecido e tampouco considerado como marginal ou "subalterno". As discussões em torno do que se chama "fazer artístico", "público de arte", "função da arte" são travadas numa esfera ampliada e podem incomodar puristas que trabalham apenas com a concepção de arte legitimada por uma única instância hermética, seja ela cultural, institucional ou teórica.

O título Amadores da arte escolhido para esta pesquisa não se deu ao acaso. O termo "amador”, sugerido pelo inglês e francês “amateur", é dúbio. Amador é quem ama - ainda que o mais correto neste caso fosse o termo amante da arte. Stebbins ${ }^{9}$ classifica a atividade do amador como uma atividade do serious leisure. O serious leisure, em contraste ao unserious leisure, é uma atividade em que as pessoas demonstram: a) perseverança, que significa a superação de momentos de dificuldade, desafio e fracassos; b) continuidade, no sentido de uma atividade que chega a constituir uma carreira de progressos; c) benefícios como auto-expressão, valorização da auto-imagem, atualização,

\footnotetext{
${ }^{8}$ Trata-se de um procedimento relativamente recente que conheci e exercitei no grupo de estudo coordenado pelo Prof. Fernando Hernandéz na Universidade de Belas Artes de Barcelona.

${ }^{9}$ Cf. STEBBINS, R. A. Amateurs, professionals and serious leisure. Montreal: McGill-Queen's University Press, 1992.
} 
desenvolvimento intelectual; d) muitas vezes desenvolvem as atividades de forma local, sem tantas estruturas de poder, e por isso não raramente estão relacionadas com subculturas; e) amadores geralmente podem falar com muita desenvoltura sobre sua prática, demonstram entusiasmo e conhecimento adquirido normalmente através de uma autogestão da aprendizagem. Para Stebbins, profissionais e amadores fazem parte de um mesmo campo, já que, muitas vezes, profissionais trabalham na formação e treinamento de amadores, ou ainda amadores constituem um significativo público de profissionais. Stebbins observa ainda que muitas vezes existe uma linguagem comum entre amadores e profissionais; no entanto, em alguns casos os amadores dispõem de uma diferente concepção da área de atuação: em alguns casos preferindo uma aproximação mais geral da área a uma especialização.

Muitas características unem e separam profissionais e amadores. Para compreender melhor uma das contradições do termo amador, podemos nos remeter ao campo esportivo, onde o termo é aplicado com maior freqüência. Nos campeonatos esportivos encontramos a categoria amadora e profissional, ambas exigem empenho e dedicação, o que as distingue é o fato de os profissionais viverem do esporte e receberem remuneração para praticá-lo, ao contrário dos amadores. Existem muitos casos em que esportistas preferem continuar na categoria amadora, por disporem de maior liberdade para escolher os campeonatos que pretendem participar, ou ainda para controlarem suas próprias rotinas de treinamento. Esportistas profissionais dispõem de menor autonomia por estarem sempre à mercê do clube ou do patrocinador.

No caso das artes plásticas, muitos artistas chamados profissionais ${ }^{10}$ também não vivem da produção artística, mas retiram seu sustento de salários da universidade, aulas em escolas e cursos, trabalhos de artes gráficas, criação de cenários, entre outros. Aliás, a profissão do artista plástico não é regulamentada no Brasil.

De forma tímida, pode-se sugerir que, nas artes visuais, a distinção habitualmente

\footnotetext{
${ }^{10}$ Cf. ARSLAN, L. M. O artista que sobrevive: Incursões profissionais de artistas plásticos formados no início do novo milênio. 2002. Dissertação de Mestrado. São Paulo: Universidade Estadual Paulista.
} 
utilizada entre amador e profissional é bastante leviana. No senso comum, profissional é aquele que faz arte como investigação pura da linguagem e amador aquele que faz arte por deleite. Mesmo aquele que vive de vender pinturas é chamado de amador se não faz arte como investigação de linguagem. Ou seja, a separação estaria, neste caso, marcada por uma concepção diferente de arte. Stebbins ${ }^{11}$ também aponta que a distinção entre profissional e amador, em algumas áreas, é determinada pela posição econômica dos praticantes.

Não se pretende aqui desqualificar a prática do amador. Amador é um nome que foi escolhido por situar-se na duvidosa distinção entre amador e profissional que existe no campo artístico. Ademais, temos consciência de que esse nome só tem sentido na arte ocidental a partir da Renascença, quando o artista adquire um status mais elevado na sociedade, como afirma o verbete do Dicionário Oxford de Arte:

Amador. Artista que trabalha puramente por prazer, e não como meio de vida. Na arte ocidental, a condição de amador só adquiriu significado com o advento da Renascença, antes do que as artes visuais eram tidas como meros oficios, sendo portanto socialmente desacreditadas. Com a mudança no status social e intelectual do artista, introduzida por homens como Leonardo, até príncipes passaram a entregar-se à sedução das artes, não apenas como patronos, mas como amadores praticantes. No século XV, René d'Anjou (143480) abriu mão de seu ducado para dedicar-se à pintura e ao paisagismo, e a Inglaterra assistiu ao surgimento de diversos aristocratas artistas amadores, entre os quais se destacam Sir Nathanael Bacon, o terceiro conde de Burlington, e o príncipe Rupert. $O$ desenvolvimento da aquarela nos séculos XVIII e XIX - par excellence o material próprio do amador causou a proliferação de pintores amadores por toda a Europa. Entre eles figuravam Goethe, e vários estadistas começaram a advogar a pintura como atividade relaxante-

\footnotetext{
${ }^{11}$ STEBBINS, R. op.cit.
} 
"um alegre passeio por uma caixa de tintas", como o expressou Sir Winston Churchil, autor de pintura como passatempo (1948). Ao mesmo tempo, a prática do desenho e da aquarela passou a compor o protótipo das jovens senhoras elegantes delineado no romance de Jane Austen (1775-1817). A rainha Vitória (1819-1991) praticava tanto a pintura quanto água forte. [...]. ${ }^{12}$

Algumas considerações sobre o amador neste verbete podem ser transpostas para a sociedade brasileira. Por exemplo, em relação à pratica artística como signo de elegância: é fácil encontrar representantes da elite econômica em revistas ou colunas sociais (como a revista Caras e nas colunas sociais dos jornais), médicos ou empresários bemsucedidos por exemplo, pintando quadros e fazendo exposições. O mesmo acontece em relação à associação bastante comum entre fazer arte e relaxamento. No entanto, o verbete acima citado traz algumas contradições no nosso contexto de produção artística, pois o artista que não trabalha com arte como meio de vida pode ser considerado um profissional, já que muitos artistas considerados profissionais no Brasil vivem com salários de outras atividades. Deste modo, o termo amador permanece convenientemente dúbio, favorecendo o uso do termo nesta investigação.

Além do termo amador, esta pesquisa refere-se a uma gama de práticas artísticas ainda sem nome. Por exemplo, utilizamos às vezes o termo praticante de arte ${ }^{13}$. Em meio a essa escolha de vocabulário adequado à conceituação do trabalho, percebemos que a forma de organizar a tese - enquanto narrativa e linguagem - oferece indícios sobre seu conteúdo. Optou-se por organizar a tese de modo a apresentar uma visão mais macrosocial no início, mapeando cursos livres e caracterizando escolas, para depois fazer uma aproximação do imaginário cultural e das concepções de arte dos seus freqüentadores. Entre os capítulos, comparecem os "Escritos do Meio", em que figuram reflexões pessoais

\footnotetext{
${ }^{12}$ CHILVERS, I. Dicionário Oxford de Arte. São Paulo: Martins Fontes, 2001, p. 16.

${ }^{13} \mathrm{O}$ termo "praticante" foi inspirado em M. de Certeau, que valoriza a interpretação das práticas cotidianas como modo de descobrir novos modos de reflexão. CERTEAU, M. de. A invenção do cotidiano. Petrópolis: Vozes, 1994.
} 
sobre o processo de reflexão (auto) etnográfica; esta escritura apresenta-se na forma de um texto livre, mais próximo do gênero ensaio. ${ }^{14}$

No primeiro capítulo são expostas as discussões teóricas que orientaram a abordagem desta pesquisa, tanto no que diz respeito à formulação metodológica quanto em relação às análises e reflexões com base no trabalho de campo.

O segundo capítulo apresenta, além dos métodos do trabalho de campo, um retrato geral dos cursos livres de pintura da cidade de São Paulo: o cenário onde estavam as distintas práticas artísticas, a apresentação desses cursos e um quadro geral dos amadores da arte.

O terceiro capítulo expõe o imaginário cultural: gostos e intenções de praticantes de pintura que buscam na arte o aperfeiçoamento técnico, a manifestação de seus sentimentos ou ainda a cognição pela e através da arte.

Nas considerações finais retomamos algumas das questões apresentadas no inicio deste trabalho. Também desenhamos nossas conclusões e fazemos algumas proposições.

\footnotetext{
${ }^{14}$ Foucault diz que o ensaio pode ser entendido "como experiência modificadora de si no jogo da verdade e não como apropriação simplificadora de outrem para fins de comunicação”. Cf. FOUCAULT, M. História da Sexualidade II. Rio de Janeiro: Graal, 1984, p. 13.
} 
ESCRITOS DO MEIO I

Nas bordas da arte 


\section{Nas bordas da arte}

Obtive uma formação em artes plásticas que valorizava a "arte pela arte", e acreditei que essa era a única prática que poderia ser sustentada no mundo contemporâneo.

No entanto, concomitante à prática artística e docente, desenvolvi estudos focados em situações que evidenciavam certa crise nesta concepção de arte autônoma. No mestrado escrevi a dissertação "O artista que sobrevive" (2002), em que procurei mostrar como muitos artistas de São Paulo mantinham suas criações à custa de outros empregos em área afins. Nesse trabalho eu tinha a intenção, longínqua, de desconstruir o mito do artista autônomo, apontando como o tempo de criação e também o custo da produção artística eram dependentes e regidos pelas "segundas" atividades dos artistas. Iniciei assim um processo de desconstrução, em que insistia em evidenciar situações contraditórias, que margeiam a prática artística e que rompiam os limites da compreensão de arte que aprendi em todas as instâncias da minha formação. Já nesse momento, não encontrava estudos que pudessem me fornecer o embasamento necessário para questionar a autonomia no campo das artes. Eu buscava, então, na sociologia a crítica que me alimentava, o que desembocou, dada a especificidade do objeto de estudo, na antropologia.

Na presente investigação, procuro pensar questões formuladas em visitas à feira de materiais artísticos da Rua Marquês de Itu, ao lado da Praça da República, no centro de São Paulo. Neste local observei uma grande quantidade de pessoas se referindo a uma prática de arte que eu não conhecia ou não reconhecia. Inicialmente, pensei em estudar apenas a feira de materiais 
artísticos da Rua Marquês de Itu. Freqüentei e observei essa feira por vários domingos. Também a feira de arte, ao lado, na Praça da República foi alvo de interesse (que para minha surpresa não tinha sido objeto de estudo na universidade). Porém, aos poucos identifiquei melhor o problema que me inquietava: as diferentes formas de relacionamento com arte e as diferentes concepções de arte que pareciam coexistir na cidade. Delimitei o cenário que melhor serviria para discutir esse problema, assim como também defini que seria preciso fazer uma pesquisa de campo, numa perspectiva empírica e etnográfica. Queria observar mais as práticas e idéias sobre arte das pessoas que se relacionavam com essas pinturas, até então estranhas a mim. Ao definir o cenário dos cursos livres, assumi a tarefa de observar outras práticas de pintura de perto, verificar se realmente se tratavam de formas distintas de se relacionar com arte, e de compreender a essência dessas práticas. Foi nesse sentido que parti para um campo de estudos quase novo; o que havia aprendido de arte novamente não me servia para entender a "arte" apresentada pelas pessoas que eu observava e entrevistava. 


\section{CAPÍTULO 1}

AMADORES DAARTE: UMAAPROXIMAÇÃO A PARTIR DE BOURDIEU, CANCLINI, M. DE CERTEAU E DOS ESTUDOS DE CULTURA VISUAL 


\section{Amadores da arte: Uma aproximação a partir de Bourdieu, Canclini, M. De Certeau e dos estudos de Cultura Visual.}

Apresenta-se a seguir as referências teóricas e metodológicas que encaminharam o processo de pesquisa e orientaram a discussão desenvolvida sobre a investigação em torno das práticas dos cursos livres de pintura. Inicialmente, relata-se o processo de aproximação e afastamento da teoria de Pierre Bourdieu para depois ser apresentada uma breve discussão sobre conceitos fundamentais para esta tese provenientes de outros autores e dos estudos da Cultura Visual.

\subsection{A contribuição de Pierre Bourdieu.}

Dois “modos de operação" propostos por Pierre Bourdieu foram importantes para uma aproximação geral dos cursos livres: seu estudo sobre as estruturas do gosto ${ }^{15}$ e a sua teoria do campo.

O conceito de campo sustentou a análise geral dos cursos livres de pintura: partiu-se dele para pensar as relações e interações entre os sujeitos dentro dos cursos de pintura e analisar as características implícitas relacionadas ao que Bourdieu chama "jogo" do campo. Para o sociólogo, cada campo possui um conjunto de leis próprias, reveladas dissimuladamente por jogos de "desinteresse" e lutas por benefícios simbólicos: entrar neste "jogo do campo" pressupõe conhecer, reconhecer e incorporar leis bastante

\footnotetext{
${ }^{15}$ Presente principalmente em: BOURDIEU, P. La distinción: critério y bases sociales del gusto. Madrid: Taurus Humanidades, 1989.
} 
subjetivas, ou seja, dispor de "sentido de jogo" (o habitus). O habitus se caracteriza por uma espécie de social incorporado manifesto quase que inconscientemente ou presente como uma segunda natureza ${ }^{16}$ : na forma de se vestir, de falar e agir ele pode ser relacionado com o que alguns autores nomeiam "imaginário cultural", que orienta gostos e comportamentos . Nesse sentido, a contribuição do sociólogo é enorme ao admitir a possibilidade em analisar a formação do gosto ou disposições culturais sem minimizar todas as dificuldades desse estudo.

Para ele a atitude desinteressada, o interesse puramente estético, ou o que ele denomina "a libido artística" são cultivados socialmente. O gosto funda-se em parte nas estruturas sociais e embora não seja uma categoria que possa ser explicada objetivamente, objetiva-se ${ }^{17}$ por meio de muitas ações como, por exemplo, na compra de móveis, na preferência por um estilo de vestuário, ou ainda na escolha de amigos. Bourdieu ${ }^{18}$ rompeu a resistência em aceitar que o gosto esteja relacionado a aspectos exteriores ao do próprio gosto em si, atuando num terreno que historicamente nega qualquer influência social.

Ao tentar definir o lugar das práticas dos cursos livres, as primeiras perguntas formuladas foram: que posição ocupam estas práticas? Todas fazem parte de um mesmo campo, possuem um mesmo habitus? Pertencem aos sistemas de arte conhecidos? Como se situam essas práticas dentro de um contexto de práticas de arte legitimada? Essas práticas podem ser compreendidas a partir de qual contexto?

Foi possível então situar os cursos livres dentro de um mesmo campo: pois mesmo com idéias e comportamentos muito distintos, eles alimentam um moto continuum. Sob a perspectiva de campo de Bourdieu, notou-se que práticas tão diferenciadas dos cursos livres poderiam ter uma função importante de "objeto de diferenciação e distinção", umas em relação às outras. Se alguns dos cursos não ocupam uma posição de luta pelo poder, e isso é fácil de perceber pela despretensão dos praticantes de algumas escolas

\footnotetext{
${ }^{16}$ Ibidem, p. 53.

17 “Objetivar", aqui, no sentido de se concretizar em algo material e exteriorizado.

${ }^{18}$ BOURDIEU, P. La distinción: criterio y bases sociales del gusto, op. cit., p. 9.
} 
pequenas, e em vista dos espaços em que buscam expor seus trabalhos e freqüentar, sempre à margem das instituições, eles possuem, sim, uma posição importante de manutenção de um campo. Nem que seja ao representar um oposto a ser negado ${ }^{19}$. Os grupos de escolas de pintura, das escolas mais caras e dos cursos ministrados em ateliês (mais próximos de um estrato da cultura legitimada), acabam por se distinguir das escolas de pequeno porte e cursos ministrados em residências dos professores. Assim, essas diferenças ajudam então a reforçar a distinção dentro do próprio campo, entre os velhos e os novos, os vulgares e os experimentais, os sentimentais e os intelectuais ${ }^{20}$. Afinal, de quem se diferenciariam os que dominam o campo da cultura se não existisse nenhuma outra espécie de produção diferenciada? Acreditamos ainda que esse movimento de distinção e diferenciação, dentro dos cursos livres de pintura, acaba por situar novos "lugares" e novas práticas dentro deste campo. Constroem-se nesse cenário, poderíamos dizer, várias "libidos artísticas" 21 . Assim, os antecedentes culturais ajudam a compreender as escolhas culturais, mas não nos ajudam a descobrir o nosso foco principal: o uso da arte que é "fabricado" 22 dentro destes espaços: um uso híbrido, ignorado pelos sistemas de legitimação, que constrói um espaço próprio e que gera suas próprias "regras da arte". Para Bourdieu, existe apenas uma regra de arte e uma libido artística:

\section{[...] los revolucionarios conservadores, paradójicamente invocan al pueblo para imponer programas regresivos en materia de arte, apoyándose sobre el filisteísmo de los no- instruidos (el que pone en evidencia, hoy, el medidor de evidencia) o, para decirlas cosas más simplemente, sobre el hecho social indiscutible de que el pueblo no quiere el arte moderno. Pero, que quiere decir esta frase? Dejo por el momento de lado la cuestión de saber lo que es necesario}

\footnotetext{
${ }^{19}$ Ibidem, p. 231.

${ }^{20}$ Fazendo uma paródia ao campo de produção de moda e a análise de diversos estilistas feita por Bourdieu, BOURDIEU, P. op. cit.

${ }^{21}$ Bourdieu se refere a uma libido artística, porque, como comenta De Certeau, trabalha a partir de estruturas estáveis. Mas se consideramos a teoria de De Certeau, podemos acreditar em várias libidos artísticas.

22 "Fabricado" parodia o conceito de fabricação criado por Michel De Certeau, que aparece detalhadamente no próximo capítulo.
} 
entender por "el pueblo". Qué quiere decir: no quiere el arte moderno? Eso quiere decir que no tiene los medios de acceso, que no tiene el código o, más precisamente, los instrumentos de conocimiento, la competencia, y de reconocimiento, la creencia, la propensión a admirar como tal, de una admiración puramente estética, lo que está socialmente designado como admirable - o que debe ser admirado - por la exposición en un museo o una galería consagrada. (...) Lo que se llama el gusto es precisamente uma capacidad de hacer diferencias, entre lo salado e lo dulce, lo moderno e lo antiguo, lo romanico y lo gótico, o entre diferentes pintores, o entre diferentes maneras de un mismo pintor, $y$, secundariamente, de probar $y$ de enunciar preferencias. Y el defecto, la ausencia, la privación de categorías de percepción y de de principios de diferenciación conduce á una indiferencia, mucho mas profunda, más profunda, más radical que la simple carencia de interés del esteta hastiado. Decir, a propósito de la gente del pueblo, que no quiere arte moderno, es bastante idiota. De hecho, eso no les concierne, no tienen nada que hacer con ello. Por qué? Porque nada ha sido hecho para constituir en ellos la libido artística, el amor al arte, que és una construcción social, un producto de la educación. ${ }^{23}$

Afastando-se da teoria de Bourdieu, esta pesquisa está mais interessada nos usos que são gerados dentro deste campo, e menos nos antecedentes que geraram esses usos. O "amor pela arte" pode estar presente em diferentes estratos sociais, e, ainda que seja distinto, é difícil afirmar que essa distinção é somente fruto de uma educação ausente. As trajetórias culturais dos amadores da arte foram investigadas para uma melhor compreensão das suas idéias sobre arte, sobre os imaginários da arte e não para identificar a origem de uma forma "dominante" ou "subordinada" de fazer arte. Essa visão de Bourdieu conduz a uma idéia de assimilação de uma visão consensual de cultura. ${ }^{24}$

\footnotetext{
${ }^{23}$ BOURDIEU, P. Creencia artística y bienes simbólicos: elementos para uma sociologia da cultura. Buenos Aires: Aurelia Rivera Grupo Cordoba y Buenos Aires, 2003, p. 31-32.

${ }^{24}$ Sobre isso consultar as produções sobre interculturalidade, como se poderá ver no capítulo 3 deste trabalho. Ver também RICHTER, I. M. op. cit., p. 34.
} 
Assim, por exemplo, vimos que parte dos amadores da arte fazem cursos de forma acelerada, para se aproximar da arte em um momento tardio de suas vidas, por isso, no caso dos cursos livres de escolas pequenas, a promessa de formação breve e acelerada é sempre constante. Alunos de outras escolas de pintura recorrem aos cursos livres porque a titulação acadêmica não lhes faz falta, porque não precisam de um título formal para certificarem sua prática cultural. Essas observações se referem aos antecedentes das práticas observadas e certamente evidenciam a grande marca de diferenciação quanto às formas de se adquirir cultura: uma total, que se adquire desde a primeira infância; e outra acelerada - trata-se da distinção de Bourdieu entre os "mundanos" e os "doctos" ou "acadêmicos". De forma que interessa identificar quais práticas artísticas podem surgir a partir destas marcas de diferenciação. Contraditoriamente, às vezes alguns desses alunos acumulam vários cursos "acelerados”, cursos de dez aulas por exemplo, e praticamente fabricam idiossincraticamente uma longa carreira de formação.

Os antecedentes das práticas são importantes para compreender as escolhas culturais, mas não decifram o uso e a aproximação dos amadores da arte. Deste modo, por um caminho diferente de Bourdieu, no lugar de analisar os antecedentes sociológicos destes "gostos", preferiu-se analisar as suas intenções e motivações atuais, e em que, apenas alguns casos, são determinantes sociais. A apropriação dos conceitos de Bourdieu levou em conta, com ressalvas, a sua forma de olhar as práticas culturais e artísticas que, segundo a qual, uma estética da privação e subordinação esquece de compreender uma outra lógica autônoma ${ }^{25}$ e independente que pode ser produzida, ou fabricada, na cotidianidade destas práticas.

Este uso "atento e ponderado" de Bourdieu é também sugerido por Néstor Garcia Canclini, ao ressaltar que na América Latina a apropriação cultural ocorre de forma menos homogênea do que no contexto europeu (onde Bourdieu realizou a maioria de suas pesquisas sobre formas de se relacionar com arte e cultura). Uma das críticas

\footnotetext{
${ }^{25}$ A autonomia aqui é apenas em relação a uma lógica de reprodução cultural e determinismos sociais, pensados numa lógica de reprodução.
} 
feitas à teoria do campo ${ }^{26}$ é que o habitus (esse sentido de jogo dentro do campo) é muitas vezes definido por Bourdieu como "uma habilidade que se desconhece", ou seja, estaria ativado não por sujeitos, mas por um lugar comum ou pelo grupo. As estratégias e o habitus atuam sobre uma estabilidade, negada por Michel de Certeau (que sequer acredita em estratégias, mas sim em táticas).

As estratégias são planos de ação sobre um território que conhece. As estratégias conhecem previamente seu alvo ou intenção, já as táticas são construções que redesenham o território, estão ao mesmo tempo ativadas por dispositivos deste, mas também estão contra ele: a tática é a arte de dar golpes no campo do outro ${ }^{27}$. Segundo M. de Certeau, não existe um trânsito lógico entre os diferentes usos da arte; não se trata de ver como acedem os grupos sobre às práticas culturais dadas. Práticas artísticas e diferentes usos da arte são também fabricados no meio desse trânsito, de maneira que não há estabilidade quando se fala em práticas culturais.

Afora as ressalvas acima levantadas, reiteramos a contribuição de Bourdieu nesta pesquisa pois sua teoria sobre o campo artístico distingue-se das teorias que reduzem o campo artístico a um reflexo espelhado do campo social.

\subsection{Canclini e De Certeau: Práticas e táticas culturais}

Nessa pesquisa adotou-se uma concepção “operativa” de cultura: consideramos como cultura todos os processos de significação e sentido presentes na vida social. Esta concepção, que valoriza os procedimentos das práticas culturais, é sugerida, como vimos, por M. de Certeau ${ }^{28}$ e também por Canclini:

\footnotetext{
${ }^{26}$ CERTEAU, M. de. op. cit., p. 125.

${ }^{27}$ Ibidem, p. 104.

${ }^{28}$ Ibidem.
} 
Se puede afirmar que la cultura abarca el conjunto de los procesos sociales de significación, o, de un modo más complejo, la cultura abarca el conjunto de procesos sociales de producción, circulación y consumo de la significación en la vida social. [...] Al conceptuar la cultura de este modo, estamos diciendo que la cultura no es apenas un conjunto de obras de arte, ni de libros, ni tampoco una suma de objetos materiales cargados de signos e simbolos. La cultura se presenta como procesos sociales, y parte de la dificultad de se hablar de ella deriva de que se produce, circula y se consume en la historia social. ${ }^{29}$

Este conceito de cultura centra-se mais em práticas do que em objetos e anuncia a sua vocação à transformação e ao movimento. Um local de trânsito que leva a abdicar de segmentos culturais dicotômicos como o popular ou erudito. Assim, nesta pesquisa evitou-se utilizar a distinção entre arte e artesanato, erudito e popular, diferenças que refletem também formas de subordinação e dependência. Esta tomada de posição referese à idéia de Canclini, de que as transições e trocas culturais contemporâneas excluem qualquer possibilidade de manter essas históricas e rígidas separações culturais.

Não se nega que possa existir uma hegemonia cultural imposta pelos campos de poder, e que existem, sim, formas subordinadas de fazer arte, conforme mostra Bourdieu. Porém, cabe perguntar se não existem formas de fazer pintura e de se relacionar com arte distintas e autônomas dessa pretensa hegemonia. Neste sentindo, a posição de Canclini converge com a idéia de fabricação de Michel de Certeau. Ao questionar a relação dicotômica entre indivíduo e sociedade, De Certeau refuta o estudo do indivíduo como fragmento tomado como modelo elementar de uma sociedade, ou mesmo a análise do indivíduo em contraponto com a sociedade. Esse parece ser o impulso inicial do chamado estudo das práticas ou "maneiras de fazer cotidianas" que se preocupam prioritariamente

\footnotetext{
${ }^{29}$ CANCLINI, N. G. Diferentes, desiguales y desconectados: mapas de la interculturalidad. Barcelona: Gedisa, 2004, p. 34.
} 
com o que se constrói entre indivíduo e sociedade. Assim como a teoria de Bourdieu, a de Michel de Certeau também é relacional, só que para De Certeau mais importante que estudar os processos de transmissão e recepção da cultura é identificar o que se produz a partir deles. É o que ele chama de fabricação:

A fabricação que se quer detectar é uma produção, uma poética - mas escondida, porque ela se dissemina nas regiões definidas e ocupadas pelo sistema da produção (televisiva, urbanística, comercial etc.) e porque a extensão sempre mais totalitária desses sistemas não deixa aos consumidores um lugar onde possam marcar o que fazem com os produtos. A uma produção racionalizada, expansionista além de centralizada, barulhenta e espetacular, corresponde outra produção qualificada de "consumo": esta é astuciosa, é dispersa, mas ao mesmo tempo ela se insinua ubiquamente, silenciosa e quase invisível, pois não se faz notar com produtos próprios mas nas maneiras de empregar os produtos impostos por uma ordem econômica dominante. ${ }^{30}$

A fabricação é um uso que se dá fora do âmbito previsível. Uma produção poética que é feita às escondidas, camuflada nos sistemas de produção, os quais não possuem espaços previstos para esse uso marginal. De Certeau destaca que marginal não se refere mais aos pequenos grupos de resistência, mas a um grande grupo não produtor de cultura legitimada, denominada por ele de "a marginalidade da maioria". Por isso ele foca seu estudo no que seria a produção dos consumidores ${ }^{31}$.

No processo de desenvolvimento desta pesquisa de cursos livres, a perspectiva de Michel de Certeau foi fundamental para interpretar as práticas artísticas que não estão dentro de um uso proposto pelas instituições e pelos sistemas de legitimação da arte, tampouco contra eles. Em suma, práticas menos reguladas por um sistema institucional legitimador. Nestes cursos emergem as já citadas táticas ${ }^{32}$, como formas de agir que se

\footnotetext{
${ }^{30}$ CERTEAU, M. de. op. cit., p. 39.

${ }^{31}$ Ibidem, p. 38.

${ }^{32}$ Ibidem.
} 
mobilizam dentro de um campo do outro.

A teoria de Michel de Certeau remete ao trabalho de Michel Foucault que não se prende à uma análise das instituições, mas sim ao estudo de "dispositivos" 33 que "vampirizam" tais instituições e reorganizam clandestinamente seus funcionamentos. Distintamente de Foucault, De Certeau não acredita que as instituições gerem apenas formas de coação e controle.

\subsection{Estudos da Cultura Visual: um modo de operar}

Para Fernando Hernandez ${ }^{34}$ a cultura visual, desde seu princípio, não pode ser objeto de uma abordagem homogênea, pois tem de dar conta de uma realidade híbrida, que deve ser tratada não por uma disciplina mas por uma $a$ disciplina, por uma iniciativa multidisciplinar de investigar que agrega disciplinas e metodologias variadas. Essa ampla gama permite abarcar como objetos de estudo: artefatos, construções e imagens presentes na cotidianidade, produzidas pela imaginação e pelo trabalho humano, que servem a um fim estético, simbólico, ritualístico ou ideológico-político e/ou a funções práticas ${ }^{35}$. Como um campo de estudos, a Cultura Visual compartilha algumas idéias de Canclini e Bourdieu ao afirmar que as imagens (que não necessariamente são visuais) são construídas socialmente. Mesmo seguindo uma tradição mais anglo-saxônica ${ }^{36}$, podemos traçar pontos convergentes entre as idéias propostas por esse campo de investigação e as idéias de

\footnotetext{
${ }^{33} \mathrm{O}$ dispositivo, discutido por Deleuze pode ser encarado como um conceito fundamental que se relaciona muito com a fabricação de De Certeau, já que é um ponto de intersecção de muitos caminhos e sentidos. Cf. DELEUZE, G. “Qu'est-ce qu'un dispositif?". Rencontre Internationale: Michel FouCAULT PHILOSOPHE, Seuil: Paris, 1989.

${ }^{34}$ HERNÁNDEZ, F. “¿De qué hablamos cuando hablamos de cultura visual?” Educação e Realidade, n. 30, v. 2, p. 10, 2005.

${ }^{35}$ TAVIN, Kevin M. "Wrestling with Angels, Searching for Ghosts: Toward a Critical Pedagogy of Visual Culture". Studies of Art Education, n. 44, v. 3, p. 197-213, 2003.

${ }^{36}$ No sentido que se referencia a autores ingleses e estadunidenses, com alguma exceção, como Debourd e Benjamin.
} 
Bourdieu e Canclini. De fato, ambas:

a) Criticam a história da arte como uma história hegemônica, que dissimuladamente reflete apenas grupos dominantes, ou, ainda, que carrega em suas formas narrativas estruturas culturais dominantes (ou estruturas estruturantes como diria Bourdieu $)^{37}$.

\section{b) Pensam na construção simultânea de uma reflexão epistemológica} e apontam a impossibilidade de se construir pesquisa cultural, sem essa reflexão sobre o campo de investigação e seus métodos, e vice-versa.

c) Acreditam que é emergente pensar nos processos de legitimação dos objetos denominados Arte, em detrimento de outros.

d) Valorizam um estudo da cultura que prioriza práticas e não objetos. Se discutir função da arte é pensar como a arte se relaciona com a vida cotidiana ${ }^{38}$, esta relação arte/vida se constrói por meio de uma concepção que se tem de arte. Na cultura ocidental, a arte teve distintas funções: religiosas, mágicas, pura reflexão sobre a linguagem, políticas etc. Esta discussão, embora antiga e por vezes óbvia, não pode ser aqui ignorada. Esclarecê-la aqui é situar o lugar de onde parte esta análise. A cultural ocidental contemporânea valoriza uma concepção de arte que salienta uma apurada investigação da linguagem e uma reflexão sobre o fazer artístico: fazer arte para pensar a arte. Ainda que movimentos de resistência como Arts and Crafts e a escola Bauhaus tenham aparecido, essa concepção, que nega qualquer relação entre arte e utilidade, praticamente rege o movimento das vanguardas artísticas a partir do movimento de arte conceitual. Muitas

\footnotetext{
${ }^{37}$ Também a historiografia da arte educação pode ser incluída nesse âmbito crítico, pois cria uma narrativa homogênea, em que se elege um sistema que vai se transmutando. A história da arteeducação se alicerça sobre uma escolha pré-definida de concepção de arte, instituições ou grupos artísticos. Assim, formas de ensino menos legitimadas pelos sistemas de controle de arte vigentes ficam quase sempre excluídas da História da Arte-Educação. Por exemplo, na literatura que aborda a história da arte-educação existe pouca referência sobre os artistas amadores ou sobre o ensino voltado para estes. No livro History of Art Education: Intellectual and Social Currentes in Teaching the Visual Arts de Efland ${ }^{37}$, cita-se brevemente que no século XVII o aprendizado amadorístico de desenho já figurava em um famoso manual para cavalheiros (gentlemans): esse era um conhecimento apontado como essencial para as anotações de viagem, mas que não deveria ser encarado como uma profissão. Não se encontram muitas outras referências sobre o ensino de artes visuais para amadores. ${ }^{38}$ PAREYSON, Luigi. Os problemas da estética. São Paulo: Martins Fontes, 1989.
} 
vezes a prática dos alunos dos cursos livres é ignorada por cumprir uma outra função, que não a de pura investigação da linguagem artística. Por isso, são apontadas como atividades “pouco artísticas", “diletantes”, ou são renegadas como arte. No entanto, também se pode notar uma grande presença da arte em outras atividades não-artísticas. A arte está presente na moda, no turismo, no urbanismo, lazer etc. Do mesmo modo existe influência de outras áreas também na arte. Nos cursos livres de pintura, emergem e sobrevivem práticas artísticas que parecem cumprir funções mistas: o hobby, o lazer, a terapia, o entretenimento, e até como forma de renda. Pensamos que uma investigação pura da linguagem aparece e às vezes se mescla, ou até inexiste, nestes cursos. Podemos ser acusados de colocar a arte em uma posição muito submissa ao defender certa "artisticidade" nas práticas dos cursos livres de pintura. Em concordância com Pareyson ${ }^{39}$, pensamos que a Arte pode, sem estar subordinada, estar em conexão simultânea com outras funções e valores que não os da arte.

\section{e) Mostram como a "pura forma" está muitas vezes regida por leis} invisíveis de aceitação, compreensão (educação) e comercialização. Este é um ponto de vista que questiona a autonomia da arte. Sociólogos ${ }^{40}$ já mostraram que a "pura forma” está muitas vezes regida por leis invisíveis de aceitação, compreensão (educação) e comercialização, assim como a falsa dicotomia entre arte como evasão, como mera inutilidade, a arte pura, em oposição à arte como aprofundamento da vida, como "engagé". Mesmo a arte sendo considerada evasão da vida, ela está intrinsecamente ligada a esta. Resta saber o que existe neste meio e reconhecer a possibilidade das suas nuanças.

f)Partem de um referencial marxista. Embora Bourdieu retome algumas idéias do marxismo, (que deixou muitas lacunas nas análises do campo cultural), sua relação com a teoria marxista é controversa no que se refere aos vínculos entre produção e cultura,

\footnotetext{
${ }^{39}$ Ibidem.

${ }^{40}$ Miceli, por exemplo, no seu livro Imagens Negociadas, mostra como nos retratos pintados por Portinari podem ser observadas características que estão relacionadas a uma negociação entre o pintor e as pessoas (importantes para a sua carreira) que retratava. Cf. MICELI, S. Imagens Negociadas. São Paulo: Companhia das Letras, 1996.
} 
a teoria do valor do trabalho, o conceito de classe social como determinante e a relação entre o econômico e o simbólico ${ }^{41}$.

Finalmente, é importante ressaltar que o campo da Cultura Visual também se preocupa em refletir a linguagem utilizada nas pesquisas: que o emprego desta esteja coerente com a proposta metodológica apresentada, ou ao menos assumidamente imprecisa, como afirmaria Wittgenstein ${ }^{42}$. Da grande gama de métodos possíveis para abordar e apresentar os objetos de estudo de Cultura Visual, dois (que estão relacionados entre si) foram aqui mais utilizados: o primeiro é denominado narrativa visual e o segundo, autoetnografia.

A narrativa visual se caracteriza por uma perspectiva mediadora; portadora de discurso, ela está vinculada às subjetividades que contribuem na construção de posições críticas em relação aos objetos de estudo da cultura visual. As narrativas referenciam a observação e o registro, ressaltam o eu como parte fundamental da investigação, falam da realidade sob o ponto de um referente. A experiência é o que estudamos, a narrativa é a representação verossímil (e não real) desta experiência. As narrativas podem ser textuais, orais, ou visuais, apresentadas em diferentes tempos narrativos (linear, circular, cíclico, espiral, ou estático e fragmentário $)^{43}$. Podem ser construídas por meio da metodologia da autoetnografia, que é uma estratégia de articulação da experiência dos sujeitos, da reconstrução das experiências da memória individual e coletiva: enfatiza a perspectiva temporal do discurso. Uma forma de repensar as relações de poder e a relação com o outro. Como um método auto-reflexivo propõe a interpretação de nossas interpretações.

Assim, a narrativa construída com base na perspectiva autoetnográfica é polifônica. Constitui-se a partir do eu, pesquisador, dos que circulam pela narrativa e dos leitores da pesquisa. Ao mesmo tempo, as narrativas são construções evocativas e

\footnotetext{
${ }^{41}$ CANCLINI, N. G. Diferentes, desiguales y desconectados: mapas de la interculturalidad, op. cit., p. 58.

${ }^{42}$ WITTGENSTEIN, L. Investigações filosóficas. México: Instituto de Investigações Filosóficas UNAM, 1988.

${ }^{43}$ BROCKMEIER, J. “Autobiographical time”. Narrative Inquiry, n. 10, v. 1, p. 51-74, 2000.
} 
proposicionais. São os referentes da narrativa nessa perspectiva: a acessibilidade (ao intencionar ser público); a transparência (apresenta uma estrutura, um processo e um resultado claro, do ponto de vista do pesquisador); a transferência (tem um compromisso com a atuação, com a posição social que está construindo. Para que serve? Para quem serve?). Na pesquisa aqui apresentada, a narrativa visual e a autoetnografia aparecerão com maior ênfase nos tratamentos das imagens e nos Escritos do Meio.

Com exceção do mapa e das tabelas, as fotos e imagens recolhidas durante o trabalho de campo não serão apresentadas como evidências. É inegável uma relação das fotos com o texto escrito; mas, mais que isso, as fotos propõem uma narrativa própria, no destaque de alguns detalhes, e na sua organização seqüencial como um curta-metragem mudo. Do mesmo modo, o registro da experiência de visitar e entrevistar os alunos, ou de pensar sobre a pesquisa formaram os Escritos do Meio: uma espécie de reflexão sobre um diário de campo construído em um momento posterior. Estes textos inseridos entre um capítulo e outro da tese possibilitam uma reflexão sobre as idéias do pesquisador em relação à interação com a sua vivência e pesquisa. Os textos em cores e formas diferentes permitem que o leitor também faça uma leitura localizada, por exemplo, lendo somente a escritura em azul, ou em preto, ou ainda passeando pelas imagens apresentadas. Com estes textos distintos pretendemos construir um corpo de reflexão narrativo transparente, polifônico e fragmentário, sem pretender uma apreensão da totalidade.

Na literatura, muitos autores utilizam textos polifônicos para ampliar o sentido de suas escrituras. Por exemplo, em Tia Júlia e o escrevinhador ${ }^{44}$, Mario Vargas Llosa cria uma interface entre duas histórias e consegue transitar entre duas linguagens literárias distintas: uma mais popularesca (escrita por um escrevinhador de novelas de rádio), e a outra mais "erudita" (escrita por um jornalista). A referência a Wittgenstein ${ }^{45}$ faz essa operação empregada por Llosa e por muitos outros escritores soar ainda mais significativa:

\footnotetext{
${ }^{44}$ LLOSA. M. V. Tia Júlia e o escrevinhador. Rio de Janeiro: Nova Fronteira, 1977.

${ }^{45}$ Wittgenstein apud CERTEAU, M. de. op. cit., p. 67.
} 
de como o mundo ordinário não pode ser representado na forma da linguagem acadêmica e como a palavra não é suficiente para representar objetos, experiências vividas ou idéias.

Essas diferentes referências servem para demonstrar que não se pretende aqui lidar apenas com a relação entre palavra e imagem, mas trata-se, antes, de assumir a parcialidade da apreensão e da representação construída sem esquecer o caráter complexo dos espaços explorados.

\section{$1.4 \mathrm{O}$ campo da Cultura Visual e a suspensão da idéia de arte}

O campo da cultura visual, distintamente das teorias de Bourdieu ${ }^{46}$ e de Canclini, suspende a idéia de arte. Neste trabalho não vamos definir ou discutir o que é ou não arte, não se está tratando aqui de objetos artísticos ou não-artísticos, estamos sim, discutindo modos e práticas de aproximação da arte. Ou seja, centra-se a preocupação nos usos e funções relacionados à arte. Trabalhamos com a hipótese de que outras concepções de arte, consideradas históricas, ainda vigorem. Assim, parte-se de três concepções tradicionais de Arte para pensar as práticas artísticas observadas: 1. Arte como fazer, que acentua o aspecto manual e artesanal arte; 2 . Arte como expressão, em que se valoriza na arte a função de expressão dos sentimentos; 3 . Arte como conhecimento, ressalta a capacidade da arte em "revelar" e conhecer a realidade por intermédio da $\operatorname{arte}^{47}$ (metafísica, espiritual ou cientificamente como fazia Da Vinci).

Estas concepções não são segmentos independentes, mas aparecem muitas vezes misturadas entre si: elas foram um ponto de referência para refletir sobre a relação

\footnotetext{
${ }^{46}$ Bourdieu não define o que é arte, mas o modo como se refere ao mundo cultural, à alta cultura, pressupõe que lida com parâmetros preestabelecidos do que é ou não arte.

${ }^{47}$ Cf. PAREYSON, L. Os problemas da estética. São Paulo: Martins Fontes, 1989. NUNES, B. Introdução à filosofia da arte. São Paulo: DESA/Edusp, 1966 (Coleção Buriti). OSBORNE. H. Estética e teoria da arte. São Paulo: Cultrix, 1993.
} 
entre concepção e função artística. A classificação de Pareyson permite pensar os dois grandes grupos de amadores: os que possuem uma relação de distanciamento estético (arte como conhecimento) e os que propõem uma relação utilitária ou engajada com a arte (arte como fazer e arte como expressão). Ademais, existem diferentes classificações dos usos da arte, como por exemplo a classificação proposta por Osborne ${ }^{48}$, que pode ser relacionada com a teoria de Pareyson, e com a relação de distanciamento estético. $\mathrm{O}$ quadro comparativo a seguir pontua na primeira coluna o principal foco da nossa observação:

\begin{tabular}{|c|c|c|}
\hline & Pareyson $^{49}$ & Osborne $^{50}$ \\
\hline $\begin{array}{l}\text { Relação } \\
\text { engajada e } \\
\text { utilitária da } \\
\text { arte. }\end{array}$ & $\begin{array}{l}\text { Arte como } \\
\text { fazer }\end{array}$ & $\begin{array}{l}\text { Interesse pragmático: Teorias instrumentais da arte: } \\
\text { (1) A arte como manufatura; (2) A arte como } \\
\text { instrumento de educação ou aprimoramento; (3) A } \\
\text { arte como instrumento de doutrinação religiosa ou } \\
\text { moral; (4) A arte como instrumento da expressão ou } \\
\text { da comunicação da emoção; (5) A arte como } \\
\text { instrumento da vicária expansão da experiência. } \\
\text { Interesse pela arte como reflexo ou cópia: teorias } \\
\text { naturalistas da arte: (1) Realismo: a arte como } \\
\text { reflexo do real; (2) Idealismo: a arte como reflexo } \\
\text { do ideal; (3) Ficção: a arte como reflexo da } \\
\text { realidade imaginativa ou do ideal inatingivel. }\end{array}$ \\
\hline $\begin{array}{l}\text { Relação de } \\
\text { distanciamento } \\
\text { estético }\end{array}$ & $\begin{array}{l}\text { Arte como } \\
\text { conhecimento }\end{array}$ & $\begin{array}{c}\text { O interesse estético: teorias formalistas da arte: (1) } \\
\text { Arte como criação autônoma; (2) A arte como } \\
\text { unidade orgânica. }\end{array}$ \\
\hline
\end{tabular}

Os gostos culturais e o interesse por fazer arte permitem identificar as concepções de arte predominantes nos cursos e explicitam visões sobre as relações entre arte e

\footnotetext{
${ }^{48}$ OSBORNE. H. Estética e teoria da arte. São Paulo: Cultrix, 1993, p. 26.

${ }^{49}$ PAREYSON, L. Os problemas da estética. São Paulo: Martins Fontes, 1989.

${ }^{50}$ Ibidem.
} 
representação, arte e sentimento, arte e vida, que explicitam a função que a arte tem para seus praticantes. Desta forma, ao considerar a subjetividade e a prática dos sujeitos acabamos por fazer análises que se aproximam do que é caracterizado como estética do $\operatorname{cotidiano}^{51}$.

\subsection{Sobre o trabalho etnográfico e as entrevistas com os freqüentadores de cursos} livres

Após visitar as escolas, as aulas foram observadas e posteriormente estabeleceram-se encontros com os alunos e freqüentadores. As entrevistas foram inicialmente gravadas com uma câmera de vídeo. A câmera provoca na maioria dos entrevistados certo desconforto, e uma elaboração maior de suas falas. Em qualquer espécie de entrevista, o entrevistado constrói um personagem ${ }^{52}$, lê as expectativas do entrevistador, e responde algo que se comunique com essa sua leitura. Neste sentido, a possibilidade de se conseguir naturalidade numa entrevista é quase nula: com ou sem câmera a situação é postiça. Entretanto, levando em conta essa artificialidade, interpretando como se dão as representações dos entrevistados e as escolhas dos papéis a serem representados, aí sim, as análises de entrevistas em vídeo podem ser bastante produtivas. O vídeo foi utilizado sem a pretensão de ser um instrumento de registro imparcial, pois sabíamos a todo o tempo de sua potencialidade de representar seletivamente o que se queria.

As entrevistas, quando semi-estruturadas - como foi neste caso -, apresentaram qualidades muito diversas de acordo com nível de atenção que o entrevistado dedicava a ela. Muitos fatores influenciaram as entrevistas; por exemplo, às vezes o aluno dispunha de pouco tempo ou a entrevista era feita em um lugar muito agitado. Também algumas

\footnotetext{
${ }^{51}$ Cf. o último capítulo desta tese, que trata da estética do cotidiano.

${ }^{52}$ GOFFMAN, E. A representação do eu na vida cotidiana. Petrópolis: Vozes, 1989.
} 
pessoas, por lidarem mais com a linguagem oral, tinham maior capacidade em estruturar o seu pensamento de forma clara. Um roteiro foi utilizado com bastante flexibilidade, incorporando mudanças, e priorizando o fluir da conversação: a ordem das perguntas era algumas vezes alterada, novas perguntas foram criadas e outras transformadas para que se evitasse o desconforto dos entrevistados. Como mostra a TABELA 1 na página a seguir, a pergunta sobre visitas a museus ou galerias era às vezes modificada perguntandose: onde você costuma ver outras pinturas? Se a resposta apresentasse outros espaços, acrescentava-se: você costuma visitar também algum museu? Num momento posterior, a pergunta, “onde você costuma ver outras pinturas?", passou a fazer parte do roteiro da entrevista: 
TABELA 1: Roteiro Base para as Entrevistas

\begin{tabular}{|c|c|c|}
\hline Área de interesse & Roteiro de perguntas & $\begin{array}{c}\text { Novas perguntas } \\
\text { acrescidas durante o } \\
\text { processo }\end{array}$ \\
\hline $\begin{array}{c}\text { Sociais/ } \\
\text { Oportunidades de } \\
\text { estudo }\end{array}$ & $\begin{array}{c}\text { Possui qual grau de escolarização? Onde } \\
\text { estudou? Escola particular ou pública? Se } \\
\text { graduado, em que e onde? Como era a aula de } \\
\text { arte na sua escola? Fez outros cursos de arte? } \\
\text { Fez outros cursos livres? Como de línguas etc.? } \\
\text { Trabalha? }\end{array}$ & \\
\hline $\begin{array}{l}\text { Interesse em fazer } \\
\text { arte e tempo de } \\
\text { dedicação }\end{array}$ & $\begin{array}{l}\text { Porque resolveu fazer curso livre de pintura? } \\
\text { Como, em sua opinião, é a melhor forma de se } \\
\text { aprender arte? Tem alguma espécie de local } \\
\text { próprio/ou casa para pintar? Com que freqüência } \\
\text { pinta? Quanto tempo por semana dedica à } \\
\text { pintura? Já participou, ou pretende participar de } \\
\text { alguma exposição? }\end{array}$ & \\
\hline $\begin{array}{c}\text { Lazer / Hábitos } \\
\text { culturais }\end{array}$ & $\begin{array}{l}\text { Quais as formas de entretenimento? O que faz } \\
\text { no seu tempo livre? Qual museu ou galeria } \\
\text { prefere? Freqüenta algum museu ou galeria de } \\
\text { arte? Quais os filmes preferidos? Quais os } \\
\text { livros preferidos? Assiste a filmes? Vai ao } \\
\text { cinema ou ao teatro? }\end{array}$ & $\begin{array}{c}\text { Onde costuma olhar } \\
\text { outras pinturas? }\end{array}$ \\
\hline $\begin{array}{l}\text { Função da arte/ } \\
\text { Concepção de } \\
\text { arte }\end{array}$ & $\begin{array}{l}\text { Qual a função da arte na sua vida? O que, } \\
\text { em sua opinião, é arte? Qual o pintor/ } \\
\text { artista ou corrente artística que prefere? } \\
\text { Com fichas (VER TABELA3)/ } \\
\text { reproduções de obras de arte: escolha } \\
\text { qual desses trabalhos você prefere como } \\
\text { pintura, e comente sua escolha. Escolha } \\
\text { um que não gosta e comente }\end{array}$ & $\begin{array}{c}\text { Você faz arte para o } \\
\text { quê?O que você acha } \\
\text { que "ganha" ao fazer } \\
\text { curso de arte?As fichas } \\
\text { com reproduções de } \\
\text { pinturas foram } \\
\text { excluídas, e assim as } \\
\text { perguntas substituídas } \\
\text { por: Que tipo de pintura } \\
\text { você gosta? Tem algum } \\
\text { pintor (a) preferido? }\end{array}$ \\
\hline
\end{tabular}


Nas primeiras entrevistas, utilizamos fichas com reproduções de obras de arte que represenatvam uma diversidade de temas, estilos e formas como mostra a tabela 2.

\section{TABELA 2: Reproduções de obras utilizadas nas entrevistas}

\begin{tabular}{|c|c|c|}
\hline A arte como modo de & A arte valorizada pela & A arte como conhecimento: \\
subjetivação, que satisfaz a & $\begin{array}{c}\text { semelhança com o real: a } \\
\text { verossimilhança. A natureza } \\
\text { ordem do coração, dos } \\
\text { corrigida: exemplos de obras } \\
\text { sentimentos e da emoção: }\end{array}$ & $\begin{array}{c}\text { sobre os sentimentos: } \\
\text { exemplos de obras em que } \\
\text { exemplos de obras com temas } \\
\text { fortes que apelem para a } \\
\text { emoção. }\end{array}$ \\
$\begin{array}{c}\text { observação da natureza } \\
\text { parece ser o interesse }\end{array}$ & $\begin{array}{c}\text { preponderam a abstração e } \\
\text { principal. }\end{array}$ \\
\hline
\end{tabular}

No entanto, excluímos as reproduções de obras logo após a primeira entrevista. Olhar as pinturas parecia ser uma tarefa muito longa, que era feita de forma abreviada. As pinturas eram muito diversas, e às vezes um aluno gostava de uma das reproduções pelas cores ou pelo tema, embora não gostasse daquele estilo. Enfim, a pergunta sobre a preferência por um estilo de pintura ou pintor parecia responder melhor ao que se queria saber, e o repertório pessoal de cada aluno ficava mais evidente. 
ESCRITOS DO MEIO II

Do desgosto 


\section{Do desgosto}

Iniciei a carreira como professora no Emporium das Artes. O tal empório era uma escola de cursos livres, onde as alunas - mulheres na maioria - queriam aprender a técnica da pintura a óleo, antes mesmo de saber desenhar.

Em alguns meses pude ensiná-las a misturar cores, preparar a tela e a copiar os temas que escolhiam: flores, paisagens, retratos da filha e do marido. Elas ficavam satisfeitas com os resultados (diria até felizes), e quanto mais aprendiam a pintar, mais se distanciavam da arte que eu queria ensinar. Assim, por desgosto, decidi levar imagens para "discutirmos pintura" em todas as aulas. Apresentava artistas modernos em grandes reproduções da coleção Gênios da Pintura; elas achavam horríveis aquelas pinturas de Picasso, Volpi e Modigliani, inclusive odiavam algumas de Monet; pensavam que esse era um momento perdido da aula, em que deixavam de pintar.

Posso dizer que o meu interesse em estudar arte-educação começou nesse momento: era urgente saber apresentar e discutir essas imagens de maneira mais efetiva (ou que elas gostassem).

Trabalhei e ensinei nessa escola até ser contratada para ser monitora da Bienal de São Paulo num momento em que as alunas já admitiam que as pinturas de Picasso eram arte, mas uma arte de que elas não gostavam. Nenhuma dessas alunas foi visitar a Bienal.

Hoje, entendo as pessoas que simplesmente não querem pensar a obra de Picasso. Também compreendo que as alunas do Emporium das Artes não eram ingênuos receptáculos de idéias sobre arte, elas sabiam o que 
queriam da e com a pintura. Inclusive, chegaram a compreender que eu estava falando de outra arte, e eu é que não entendia "a outra" arte delas.

Com a minha estratégia de apresentar a arte de forma cronológica eu conseguiria transformá-las em "modernísticas", mas nunca em modernas. E eu tinha o forte desejo de transformá-las em Louises Bourgeoises, mas elas resistiriam, independente das minhas estratégias de ensino. Ainda que eu persista escolhendo - para o meu deleite - as imagens de um trauma paternal de Louise Bourgeois, me alivia saber que nem todos os espaços reproduzem suas idéias. Hoje substituo as estratégias de ensino pelas táticas de ensino (adotando o conceito de De Certeau).

Atualmente, diante de alunas como as que tive no Emporium das Artes, aproveitaria para descobrir suas motivações frente à arte. Admitir diferentes intenções ao fazer arte me faz mais flexível e interessada. Reconhecer a concepção de arte que regeu a minha formação, e a parcialidade do meu conhecimento, permite-me transitar em um espaço diferente. Posso rir, inclusive, de como sustentava ingênuas aspirações no campo da arte, acompanhadas de reproduções dos Gênios da Pintura, que carregava com tanto gosto, nas pesadas encadernações kitsch de couro. 


\section{CAPÍTULO 2}

\section{CARACTERIZAÇÃO GERAL DOS CURSOS LIVRES}




\section{Caracterização geral dos cursos livres}

Situar melhor o cenário onde ocorrem as práticas e se encontram os amadores da arte foi fundamental para dimensionar a quantidade e a variedade ofertada aos interessados em pintura - o ponto de partida para localizar seus freqüentadores e suas idéias sobre arte. A amostra dos cursos livres aqui apresentados foi organizada a partir de diferentes fontes: prospectos de propagandas, anúncios na Internet e lista telefônica, além de indicações de amigos e profissionais sobre os cursos de pintura que conheciam. Contatadas as escolas, perguntou-se: sua localização, o valor cobrado por aula, média de alunos e a formação do professor de pintura. Algumas perguntas despertaram uma atitude de desconfiança, outras geraram uma agradável conversa.

Colocou-se em foco na observação dos cursos localizados na região do centro expandido de São Paulo, região onde existe grande oferta de equipamento cultural: cursos superiores de arte, galerias, museus, centro culturais, ateliês de artistas entre outros. Esta escolha evita a discussão entre centro e periferia: que geraria argumentos que justificariam algumas escolhas culturais por falta de opção na região. Em meio à grande oferta do centro da cidade é possível perceber como as escolhas e usos da arte são diferenciados.

A seguir, o MAPA 1 apresenta a localização de uma amostra de cursos de pintura oferecidos no centro expandido da cidade de São Paulo.

A partir dos 33 cursos mapeados, muitas poderiam ser as formas de classificar estes cursos: por quantidade de alunos, formação do professor, tipo de instituição que o oferece, valor da mensalidade, programa ou proposta de curso, localização etc: 
MAPA 1: Localização da amostra dos cursos de pintura da região do centro expandido de São Paulo.

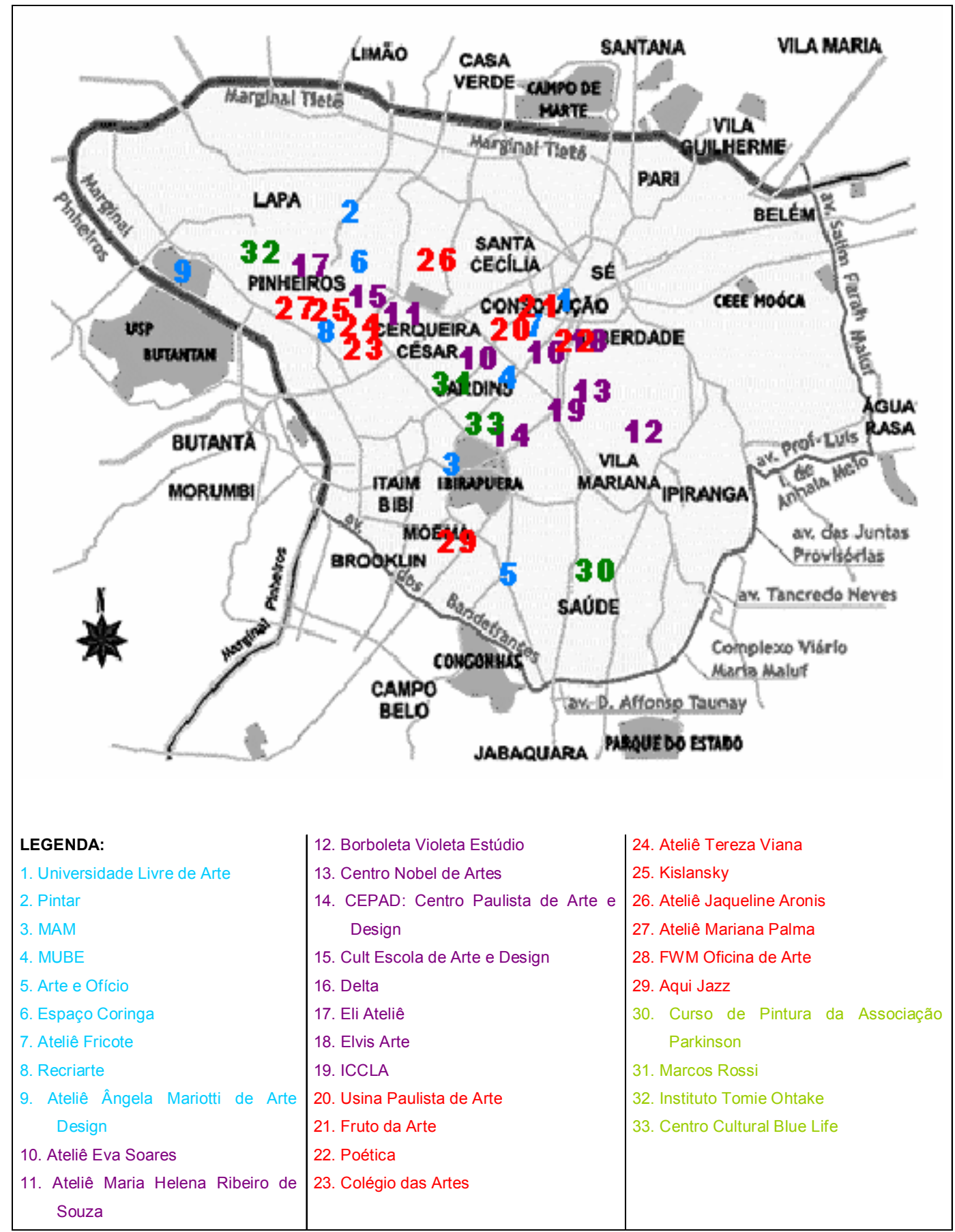


TABELA 3: Cursos livres na cidade de São Paulo

\begin{tabular}{|c|c|c|c|c|}
\hline $\begin{array}{c}\text { NOMEDA } \\
\text { ESCOLAOU } \\
\text { ATELÊE }\end{array}$ & $\begin{array}{l}\text { ENDEREÇO/ } \\
\text { TELEFONE }\end{array}$ & $\begin{array}{l}\text { HORÁRIOS } \\
\text { EVALOR }\end{array}$ & $\begin{array}{c}\text { NOME E FORMAÇÃO DO } \\
\text { PROFESSOR }\end{array}$ & $\begin{array}{c}\text { QTDEMÉDIA } \\
\text { MENSALDE } \\
\text { ALUNOS }\end{array}$ \\
\hline $\begin{array}{l}1 . \\
\text { Universidade } \\
\text { Livre de Arte - } \\
\text { ULA }\end{array}$ & $\begin{array}{c}\text { R. Epitácio } \\
\text { Pessoa, } 91 \\
\text { Centro }\end{array}$ & $4^{\mathrm{a}}$ à noite & $\begin{array}{c}\text { Rubens Espírito Santo } \\
\text { O professor estudou arte na } \\
\text { Alemanha com um filósofo } \\
\text { que foi um dos fundadores } \\
\text { da Internacional } \\
\text { Situacionista, mas nunca fez } \\
\text { uma graduação formal. }\end{array}$ & 12 alunos \\
\hline $\begin{array}{l}\text { 2. Pintar - arte e } \\
\text { artesanato }\end{array}$ & $\begin{array}{c}\text { R. Cotoxó, } 110 \\
\text { Pompéia } \\
\text { Tel } 38730099\end{array}$ & $\begin{array}{c}2^{\mathrm{a}} \text { e } 5^{\mathrm{a}} \\
\text { das } 9 \mathrm{~h} \text { às } 12 \mathrm{~h} \\
\mathrm{R} \$ 150,00\end{array}$ & $\begin{array}{c}\text { Poyares } \\
\text { A secretária não soube } \\
\text { informar a formação do } \\
\text { professor }\end{array}$ & 4 alunos \\
\hline $\begin{array}{l}\text { 3. Museu de } \\
\text { Arte de São } \\
\text { Paulo - MAM/ } \\
\text { SP }\end{array}$ & $\begin{array}{c}\text { Parque do } \\
\text { Ibirapuera } \\
\text { Tel } 50851313 \\
\text { e } 50851312\end{array}$ & $\begin{array}{l}4^{\mathrm{a}} \text { tarde ou } \\
\text { noite } \\
\mathrm{R} \$ 150,00\end{array}$ & $\begin{array}{l}\text { Sérgio Niculitcheff } \\
\text { O professor/artista é } \\
\text { formado na Faculdade Belas } \\
\text { Artes e também é professor } \\
\text { da Faculdade Integradas de } \\
\text { Guarulhos. }\end{array}$ & 15 \\
\hline 4. MUBE & $\begin{array}{l}\text { Av. Europa, } \\
218 \\
\text { Jd. Europa } \\
\text { Tel 3081 } 8611\end{array}$ & $\begin{array}{c}4^{\mathrm{a}} \text { tarde } / 3^{\mathrm{a}} \\
\text { noite } \\
5^{\mathrm{a}} \text { tarde } \\
5^{\mathrm{a}} \text { noite } \\
\mathrm{R} \$ 230,00 \text { (uma } \\
\text { vez por } \\
\text { semana) }\end{array}$ & $\begin{array}{c}\text { Eduardo Werneck } \\
\text { Paulo Whitaker } \\
\text { Vera Martins } \\
\text { Segundo a secretária Célia } \\
\text { alguns professores são } \\
\text { artistas "renomados", } \\
\text { outros são professores } \\
\text { universitários. As } \\
\text { entrevistas com os alunos } \\
\text { puderam ser feitas depois } \\
\text { de uma conversa com os } \\
\text { professores. }\end{array}$ & $\begin{array}{c}\text { cerca de } 20 \\
\text { alunos no } \\
\text { total }\end{array}$ \\
\hline
\end{tabular}




\begin{tabular}{|c|c|c|c|c|}
\hline $\begin{array}{l}\text { 5. Arte e Ofício } \\
\text { (escola de } \\
\text { joalheria que } \\
\text { cede a sala } \\
\text { para o } \\
\text { professor ) }\end{array}$ & $\begin{array}{c}\text { Av. } \\
\text { Piassanguaba, } \\
3003 \\
\text { Saúde } \\
\\
\text { Tel } 50729509\end{array}$ & $\begin{array}{c}4^{\mathrm{a}} \text { à noite } \\
\text { das } 19 \mathrm{~h} \text { às } 22 \mathrm{~h} \\
\text { (podem abrir } \\
\text { novas turmas } \\
\text { se houver } \\
\text { procura) } \\
\text { R\$ } 120,00\end{array}$ & $\begin{array}{l}\text { Prot. Altredo } \\
\text { Foi aluno e professor da } \\
\text { Faculdade Belas Artes e } \\
\text { também do Liceu de Artes e } \\
\text { Ofício de São Paulo }\end{array}$ & 5 alunos \\
\hline $\begin{array}{l}\text { 6. Ateliê } \\
\text { Espaço } \\
\text { Coringa }\end{array}$ & $\begin{array}{c}\text { R. Fradique } \\
\text { Coutinho, } 934 \\
\text { - casa } 2 \\
\text { Vila Madalena } \\
\text { Tel } 38138741 \\
\text { www.espacocoringa.com.br }\end{array}$ & $\begin{array}{l}4^{\mathrm{a}} \text { tarde } / 6^{\mathrm{a}} \\
\text { noite } \\
\text { (aulas de } 3 \\
\text { horas) } \\
\mathrm{R} \$ 100,00 \\
\text { mensais }\end{array}$ & $\begin{array}{l}\text { Matheus é o professor de } \\
\text { pintura. É um ateliê coletivo } \\
\text { que existe há } 5 \text { anos e onde } \\
\text { os artistas que nele } \\
\text { trabalham ministram aulas. } \\
\text { Todos são formados em } \\
\text { Artes Plásticas na FAAP ou } \\
\text { na ECA. Matheus } \\
\text { comentou que a maioria dos } \\
\text { alunos também são } \\
\text { universitárias e/ou pós- } \\
\text { graduados. Boa parcela } \\
\text { deles já tem contato com } \\
\text { artes visuais pois estudam } \\
\text { cinema ou publicidade. Ele } \\
\text { comentou que é um perfil } \\
\text { diferente dos alunos que } \\
\text { querem pintar "marinhas" } \\
\text { (estes, quando procuram o } \\
\text { Ateliê, logo na primeira } \\
\text { conversa “fogem"). Muitos } \\
\text { alunos, por exemplo, querem } \\
\text { pintar sem nunca ter } \\
\text { desenhado, e ele começa o } \\
\text { curso muitas vezes com aula } \\
\text { de desenho. }\end{array}$ & $\begin{array}{l}5 \text { alunos (em } \\
\text { média, mas } \\
\text { alguns alunos } \\
\text { do ateliê livre } \\
\text { também } \\
\text { frequentam as } \\
\text { aulas de } \\
\text { pintura) }\end{array}$ \\
\hline $\begin{array}{l}\text { 7. Ateliê } \\
\text { Fricote Escola } \\
\text { e Galeria }\end{array}$ & $\begin{array}{l}\text { R. Marquês } \\
\text { de Itu, } 266 \\
\text { V. Buarque } \\
\text { Tel3331 } 8797\end{array}$ & $\begin{array}{c}\text { Aulas uma vez } \\
\text { por semana } \\
\text { (horários a } \\
\text { combinar) } \\
\text { R } \$ 80,00\end{array}$ & $\begin{array}{c}\text { O professor é autodidata. } \\
\text { Teve aula com o artista } \\
\text { Miguel Lopes }\end{array}$ & 30 alunos \\
\hline
\end{tabular}




\begin{tabular}{|c|c|c|c|c|}
\hline 8. Recriarte & $\begin{array}{l}\text { R. Fradique } \\
\text { Coutinho, } 994 \\
\text { PinheirosFone: } \\
\quad 30345598\end{array}$ & $\begin{array}{c}\text { Uma vez por } \\
\text { semana (todos } \\
\text { os dias manhã } \\
\text { ou tarde ou } \\
3^{\mathrm{a}} \text { e } 6^{\mathrm{a}} \text { à noite) } \\
\mathrm{R} \$ 2.400,00 \\
\text { anual } \\
\text { (à vista com } \\
50 \% \text { desconto } \\
\text { ou R\$ 200,00 } \\
\text { p/ mês) }\end{array}$ & $\begin{array}{l}\text { Seis professores } \\
\text { coordenados por Regina } \\
\text { Castellani. } \\
\text { A maioria dos professores é } \\
\text { formada, alguns na própria } \\
\text { escola. Wladimir informou } \\
\text { que para as entrevistas seria } \\
\text { indicada uma conversa } \\
\text { inicial com a coordenadora } \\
\text { na terça-feira, antes da aula. }\end{array}$ & $\begin{array}{c}\text { Média de } 30 \\
\text { alunos }\end{array}$ \\
\hline $\begin{array}{l}\text { 9. Ateliê Ângela } \\
\text { Mariotti Arte } \\
\text { Design }\end{array}$ & $\begin{array}{c}\text { R. Todoro } \\
\text { Quartim } \\
\text { Barbosa, } 66 \\
\text { Vila. S. Fco } \\
\text { (perto da } \\
\text { entrada da } \\
\text { Escola } \\
\text { Politécnica da } \\
\text { USP) } \\
\text { Tel } 37662942\end{array}$ & $\begin{array}{l}\text { Manhã, tarde } \\
\text { ou noite } \\
\text { durante a } \\
\text { semana e } \\
\text { sábado } \\
\text { matutino }\end{array}$ & $\begin{array}{l}\text { A professora é catalogada no } \\
\text { Dicionário Brasileiro de } \\
\text { Arte. Estudou com outros } \\
\text { mestres que estudaram na } \\
\text { Itália como Pedro Alzaga. }\end{array}$ & $\begin{array}{c}\text { Cerca de } 22 \\
\text { alunos }\end{array}$ \\
\hline $\begin{array}{l}\text { 10. Ateliê Eva } \\
\text { Soares }\end{array}$ & $\begin{array}{l}\text { R. Augusta, } 541 \\
\text { - apto } 8 \mathrm{~d} \\
\text { Tel } 31202554\end{array}$ & $\begin{array}{c}\text { Aulas somente } \\
\text { com horário } \\
\text { marcado. } \\
\text { Existe o curso } \\
\text { de "abstrato" } \\
\text { que, na maioria } \\
\text { das vezes, } \\
\text { recebe pessoas } \\
\text { de outras } \\
\text { cidades, estados } \\
\text { e países (ela } \\
\text { havia recebido } \\
\text { uma suíça e uma } \\
\text { angolana na } \\
\text { mesma semana). }\end{array}$ & $\begin{array}{l}\text { Eva Soares } \\
\text { Estudou em vários cursos de } \\
\text { técnicas de pintura na } \\
\text { Europa. } \\
\end{array}$ & $\begin{array}{l}35 \text { alunos } \\
\text { (no } \\
\text { momento da } \\
\text { entrevista, } \\
\text { por ser fim } \\
\text { de ano, } \\
\text { contava } \\
\text { apenas } 3 \\
\text { alunas). }\end{array}$ \\
\hline
\end{tabular}




\begin{tabular}{|c|c|c|c|c|}
\hline $\begin{array}{l}\text { 11. Ateliê Maria } \\
\text { Helena Ribeiro } \\
\text { de Souza }\end{array}$ & $\begin{array}{c}\text { Rua Ucaiari, } \\
\text { 235, Alto de } \\
\text { Pinheiros, } \\
\text { 05468-030.Fone: } \\
\text { (11)3022-7601 }\end{array}$ & $\begin{array}{c}5^{\mathrm{a}} \text { ocorre } 5 \text { a } 6 \\
\text { aulas por dia. } \\
\text { Ensinam } \\
\text { técnicas com } \\
\text { tinta acrílica, } \\
\text { óleo e aquarela. } \\
\text { É possível } \\
\text { chegar de } \\
\text { manhã e ficar } \\
\text { até o fim do dia. } \\
\text { R\$ 220,00 por } \\
\text { mês. }\end{array}$ & $\begin{array}{c}\text { A professora aprendeu a } \\
\text { pintar em ateliês de outros } \\
\text { artistas. }\end{array}$ & 8 alunos \\
\hline $\begin{array}{l}\text { 12. Borboleta } \\
\text { Violeta Estúdio }\end{array}$ & $\begin{array}{l}\text { Rua Tangará, } \\
201 \\
\text { Vila Mariana } \\
\text { Tel } 55728837\end{array}$ & $\begin{array}{c}3^{\mathrm{a}} \text { e } 5^{\mathrm{a}} \text { matutino } \\
3^{\mathrm{a}} \text { vespertino/ } \\
2^{\mathrm{a}} \text { noturno } \\
\text { (uma vez por } \\
\text { semana) } \\
\mathrm{R} \$ 230,00 \\
\text { e R\$ } 198,00 \\
\text { por bimestre }\end{array}$ & $\begin{array}{l}\text { Francisco D’Oliveira } \\
\text { Professor de desenho e } \\
\text { pintura, é artista plástico } \\
\text { formado pela Belas Artes de } \\
\text { S. Paulo e especializado em } \\
\text { História da Arte (Faap). }\end{array}$ & 15 alunos \\
\hline $\begin{array}{l}\text { 13. Centro } \\
\text { Nobel de Artes }\end{array}$ & $\begin{array}{c}\text { Av. Brigadeiro } \\
\text { Luiz Antônio, } \\
4959 \\
\text { Jd. Paulista } \\
\text { Tel } 38854205\end{array}$ & & & \\
\hline $\begin{array}{l}\text { 14.Cepade } \\
\text { Centro Paulista } \\
\text { de Arte e } \\
\text { Design }\end{array}$ & $\begin{array}{l}\text { R Urubatuba, } \\
\qquad 100 \\
\text { Vila Mariana } \\
\text { Tel 5594-8471 }\end{array}$ & $\begin{array}{c}\mathrm{R} \$ 140,00 \\
\text { mensais (uma } \\
\text { vez por } \\
\text { semana) } \\
\text { ou } \\
\mathrm{R} \$ 170,00 \\
\text { mensais (duas } \\
\text { vezes por } \\
\text { semana) }\end{array}$ & Formação variada & $\begin{array}{c}\text { Cerca de } 30 \text { a } \\
40 \text { alunos }\end{array}$ \\
\hline
\end{tabular}




\begin{tabular}{|c|c|c|c|c|}
\hline $\begin{array}{l}\text { 15. Cult Escola } \\
\text { e Arte S/C Ltda }\end{array}$ & $\begin{array}{c}\text { Pça. Américo } \\
\text { Jacomino, } 63 \\
\text { Sumarezinho } \\
\text { Tel } 38650009 \\
\text { (em frente ao } \\
\text { metrô Vila } \\
\text { Madalena) }\end{array}$ & $\begin{array}{c}\text { Manhã: só no } \\
\text { sábado/ Tardes: } \\
2^{\mathrm{a}}, 4^{\mathrm{a}} \text { e } 6^{\mathrm{a}} / \\
\text { Noites: } 4^{\mathrm{a}} \\
\text { R\$ 150,00 (uma } \\
\text { vez por semana, } \\
3 \text { horas de aula) } \\
\text { A matrícula: } 50 \\
\text { reais e mais } \\
\text { quatro parcelas } \\
\text { de } 80 \text { reais }\end{array}$ & $\begin{array}{c}\text { Débora Miller } \\
\text { Ao que parece Débora é } \\
\text { artista plástica, pós- } \\
\text { graduada em História em } \\
\text { Quadrinhos e faz mestrado } \\
\text { (informações pouco precisas } \\
\text { fornecidas pela entrevistada } \\
\text { parecem pouco coerentes) }\end{array}$ & $\begin{array}{l}25 \text { a } 30 \\
\text { alunos }\end{array}$ \\
\hline $\begin{array}{l}\text { 16. Delta Ateliê } \\
\text { de Artes }\end{array}$ & $\begin{array}{c}\text { R.Alm. } \\
\text { Marques Leão, } \\
826 \\
\text { Bela Vista } \\
\text { Tel } 32830556\end{array}$ & $\begin{array}{c}\text { Manhã, tarde e } \\
\text { noite na } 2^{\mathrm{a}}, 3^{\mathrm{a}} \\
\text { ou } 4^{\mathrm{a}} \\
\text { (3 horas de } \\
\text { aula) } \\
\text { Plano mensal: } \\
\text { R\$ 290,00 com } \\
\text { material } \\
\text { incluído para o } \\
\text { primeiro } \\
\text { módulo. } \\
\text { Semestral e } \\
\text { anual R\$ } \\
\text { 240,00. Aula } \\
\text { individual (2 } \\
\text { professoras } \\
\text { para no } \\
\text { máximo } 6 \\
\text { alunos) }\end{array}$ & $\begin{array}{l}\text { Professoras: Maria José } \\
\text { (entrevistada) e Carla são } \\
\text { formadas na Faculdade } \\
\text { Santa Marcelina. No curso, } \\
\text { elas falam de história da } \\
\text { arte, levam a exposições, e } \\
\text { no final do ano promovem } \\
\text { uma exposição para os } \\
\text { alunos compreenderem um } \\
\text { pouco como funcionam } \\
\text { esta parte do fazer artístico. } \\
\text { Algumas pessoas iniciaram } \\
\text { por lazer, mas agora já fazem } \\
\text { exposições e vendem seus } \\
\text { quadros. Alguns alunos } \\
\text { traziam o programa do } \\
\text { vestibular. Cada pessoa } \\
\text { tem o seu interesse e } \\
\text { tempo. }\end{array}$ & 20 alunos \\
\hline $\begin{array}{l}\text { 17.Eli Art Ateliê } \\
\text { de Pinturas e } \\
\text { Artesanatos }\end{array}$ & $\begin{array}{c}\text { Av. Pompéia, } \\
1976 \\
\text { Pompéia } \\
\text { Tel 3675-0442 }\end{array}$ & $\begin{array}{c}\text { Manhã: } 3^{\mathrm{a}} \mathrm{e} \\
\text { sábado/ Tarde: } \\
3^{\mathrm{a}}, 6^{\mathrm{a}} \text { e } 4^{\mathrm{a}} / \\
\text { Noite: } 3^{\mathrm{a}} \text {. } \\
\text { Aceitam alunos } \\
\text { a partir de } 5 \\
\text { anos. Também } \\
\text { trabalham com } \\
\text { arte-terapia e } \\
\text { terapia } \\
\text { ocupacional }\end{array}$ & $\begin{array}{l}\text { Eliana Andriguette Silva, a } \\
\text { professora entrevistada } \\
\text { informou que iniciou a } \\
\text { Faculdade Santa Marcelina } \\
\text { mas desistiu porque a } \\
\text { apresentava muita teoria, } \\
\text { muita história, e ela estava } \\
\text { mais interessada na prática. } \\
\text { Formou-se com dois } \\
\text { professores: Paulo Caglio e } \\
\text { Francisco Cuoco. Começou }\end{array}$ & $\begin{array}{c}\text { Entre } 14 \text { e } 15 \\
\text { alunos }\end{array}$ \\
\hline
\end{tabular}




\begin{tabular}{|c|c|c|c|c|}
\hline & & & $\begin{array}{l}\text { por hobby. Comentou que a } \\
\text { maior parte dos alunos } \\
\text { procura suas aulas para } \\
\text { relaxar e combater o estresse, } \\
\text { síndrome do pânico, etc. } \\
\text { Também leciona para } \\
\text { pessoas da terceira idade } \\
\text { (tem um aluno de } 91 \text { anos). } \\
\text { Ouve as "lamúrias", tenta } \\
\text { passar “coisas boas". Está } \\
\text { fazendo graduação. }\end{array}$ & \\
\hline 18. Elvis Arts & $\begin{array}{l}\text { R. Marquês de } \\
\quad \text { Itú, } 335 \\
\text { Tel } 33332182\end{array}$ & $\begin{array}{c}2^{\mathrm{a}} \text { à } 6^{\mathrm{a}} \\
\text { das } 9 \mathrm{~h} 30 \text { às } \\
12 \mathrm{~h} 30 ; 14 \mathrm{~h} \text { às } \\
17 \mathrm{~h} . \text { Sábados e } \\
\text { domingos das } \\
9 \mathrm{~h} 30 \text { ás } 12 \mathrm{~h} . \\
\mathrm{R} \$ 100,00(4 \\
\text { aulas por mês) }\end{array}$ & $\begin{array}{l}\text { Os dois professores, não } \\
\text { possuem formação } \\
\text { universitária; fizeram vários } \\
\text { cursos, dentro e fora do no } \\
\text { Brasil. A dona da Escola foi } \\
\text { reticente quanto a deixar } \\
\text { assistir a uma aula e } \\
\text { entrevistar seus alunos. }\end{array}$ & 80 alunos \\
\hline $\begin{array}{l}\text { 19. Escola de } \\
\text { Arte ICCLA - } \\
\text { Instituto de } \\
\text { Cultura } \\
\text { Ciências Letras } \\
\text { e Artes. }\end{array}$ & $\begin{array}{l}\text { R. Domingos de } \\
\text { Morais, } 770 \text { - } \\
\text { bloco 3, apto } 63 \\
\text { Tel } 55725309 \\
\text { Próximo ao } \\
\text { metrô Ana } \\
\text { Rosa }\end{array}$ & $\begin{array}{c}3^{\mathrm{a}} \text { manhã/ } 4^{\mathrm{a}} \\
\text { manhã e tarde / } \\
5^{\mathrm{a}} \text { noite } \\
\mathrm{R} \$ 40,00 \text { por } \\
\text { aula e R\$ } \\
\text { 120,00 por mês } \\
\text { Massa acrílica, } \\
\text { apostila e } \\
\text { certificado. O } \\
\text { aluno não pode } \\
\text { escolher o } \\
\text { modelo. }\end{array}$ & $\begin{array}{c}\text { Prof. Jandilisa Grassano } \\
\text { Formada em "Belas Artes" } \\
\text { na faculdade de Belas Artes. }\end{array}$ & $\begin{array}{l}40 \text { alunos } \\
\text { (máximo } 6 \\
\text { alunos por } \\
\quad \text { aula) }\end{array}$ \\
\hline $\begin{array}{l}\text { 20. Usina } \\
\text { Paulista de Arte }\end{array}$ & $\begin{array}{c}\text { R. São } \\
\text { Domingos, } 237 \\
\text { Bela Vista } \\
\text { Tel } 31046459\end{array}$ & $\begin{array}{l}\mathrm{R} \$ 120,00 \\
\text { (uma vez por } \\
\text { semana) }\end{array}$ & $\begin{array}{c}\text { Profa. Vera Martins } \\
\text { (a mesma professora do } \\
\text { MUBE) }\end{array}$ & $\begin{array}{c}\text { O curso foi } \\
\text { anunciado em } \\
\text { fevereiro mas } \\
\text { não formaram } \\
\text { turmas (até } \\
\text { julho de } \\
\text { 2005). }\end{array}$ \\
\hline
\end{tabular}




\begin{tabular}{|c|c|c|c|c|}
\hline $\begin{array}{l}\text { 21. Fruto da } \\
\text { Arte }\end{array}$ & $\begin{array}{l}\text { R. Marquês de } \\
\text { Itu. }\end{array}$ & $\begin{array}{l}3^{\mathrm{a}} \text { de manhã ou } \\
\text { à noite } \\
\mathrm{R} \$ 150,00 \\
\text { (uma vez por } \\
\text { semana) }\end{array}$ & $\begin{array}{c}\text { O professor Enip não tem } \\
\text { graduação, é autodidata e } \\
\text { expõe aos domingos na Pça. } \\
\text { da República. Também faz } \\
\text { uma série de cursos por fitas } \\
\text { de vídeo e DVD, que vende } \\
\text { para o Brasil todo. }\end{array}$ & 22 alunos \\
\hline 22. Poética & $\begin{array}{l}\text { R. Humaitá, } 537 \\
\text { Cel } 71540678\end{array}$ & $\begin{array}{c}\text { Aulas } \\
\text { individuais para } \\
\text { adultos } \\
\mathrm{R} \$ 80,00 \text { por } \\
\text { mês + R } \$ 15,00 \\
\text { de material. }\end{array}$ & $\begin{array}{c}\text { Prof. Da JuliaÉ formado em } \\
\text { Artes Visuais em Nova } \\
\text { Hamburgo. }\end{array}$ & $?$ \\
\hline $\begin{array}{l}\text { 23. Collegio das } \\
\text { Artes }\end{array}$ & $\begin{array}{c}\text { R. Francisco } \\
\text { Leitão, } 265 \\
\text { Pinheiros } \\
\\
\text { Tel } 34835797\end{array}$ & $\begin{array}{c}\text { Outubro } \\
2^{\mathrm{a}} 19 \mathrm{~h} 30 \mathrm{a} \\
21 \mathrm{~h} 30 \\
\\
\mathrm{R} \$ 250,00 \text { por } \\
\text { mês (um } \\
\text { encontro } \\
\text { semanal) }\end{array}$ & $\begin{array}{c}\text { Pintura avançado com Marco } \\
\text { Gianotti, Teresa Viana, Vera } \\
\text { Martins, Eduardo Werneck e } \\
\text { Paulo Whitaker. } \\
\text { Essa escola é uma } \\
\text { dissidência da escola do } \\
\text { MUBE. Formação variada, } \\
\text { professores graduados, com } \\
\text { formação no Parque Lage, } \\
\text { Escola do Louvre etc. }\end{array}$ & 40 alunos \\
\hline 24. Teresa Viana & $\begin{array}{c}\text { R. Fidalga, } 575 \\
\text { casa } 3 \\
\text { V. Madalena } \\
\text { Tel } 30345940 \\
\text { Cel } 95254764\end{array}$ & & $\begin{array}{c}\text { A professora tem formação } \\
\text { no Parque Lage - RJ. }\end{array}$ & 4 alunas \\
\hline $\begin{array}{l}25 \text { Kislansky } \\
\text { Ateliê de } \\
\text { Escultura }\end{array}$ & $\begin{array}{c}\text { R. Teodoro } \\
\text { Sampaio, } 855 \text { - } \\
\text { apto } 13 \\
\text { Tel } 30625323\end{array}$ & 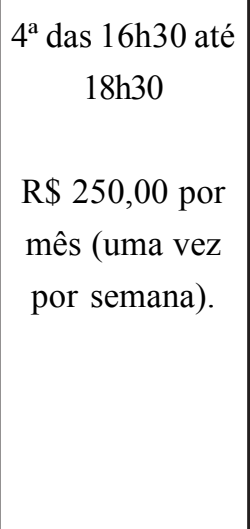 & $\begin{array}{c}\text { O foco principal são as aulas } \\
\text { de escultura dadas por Israel } \\
\text { Kislansky, graduado pela } \\
\text { Faciuldade Santa Marcelina. } \\
\text { Há também aulas de pintura } \\
\text { dadas por vários artistas, } \\
\text { como o professor Luiz A. De } \\
\text { Genaro, graduado pelo Santa } \\
\text { Marcelina e mestre pela } \\
\text { ECA- USP. }\end{array}$ & $\begin{array}{l}\text { Cerca de } 50 \\
\text { alunos, } \\
\text { contando na } \\
\text { maioria os } \\
\text { alunos de } \\
\text { escultura. }\end{array}$ \\
\hline
\end{tabular}




\begin{tabular}{|c|c|c|c|c|}
\hline $\begin{array}{l}\text { 26. Jaqueline } \\
\text { Aronis }\end{array}$ & $\begin{array}{l}\text { R. Piauí, } 1174 \\
\text { - casa } 74 \\
\\
\text { Tel } 36635216 \\
\text { e } 36673552\end{array}$ & $\begin{array}{c}2^{\mathrm{a}} \text { das } 14 \mathrm{~h} \text { às } \\
16 \mathrm{~h} \text { e à noite } \\
\text { das } 19 \mathrm{~h} 30 \text { às } \\
21 \mathrm{~h} \\
\mathrm{R} \$ 260,00 \text { por } \\
\text { mês (cobra taxa } \\
\text { de } \mathrm{R} \$ 100,00 \\
\text { pelo modelo } \\
\text { vivo) }\end{array}$ & $\begin{array}{l}\text { Faz doutorado na ECA, dá } \\
\text { aula em duas universidades. }\end{array}$ & 5 alunos \\
\hline $\begin{array}{l}\text { 27. Mariana } \\
\text { Palma }\end{array}$ & $\begin{array}{l}\text { Tel } 38123044 \\
\text { Cel } 81969337\end{array}$ & $\mathrm{R} \$ 100,00$ & $\begin{array}{l}\text { A professora é formada em } \\
\text { Artes Plásticas na FAAP . A } \\
\text { Mariana disse não se sentir } \\
\text { segura para apresentar a sua } \\
\text { aluna e disse que ela não } \\
\text { seria uma pessoa adequada } \\
\text { para a minha pesquisa } \\
\text { (apesar das explicações). }\end{array}$ & 1 aluna \\
\hline $\begin{array}{l}\text { 28. Ateliê } \\
\text { Oficina FWM } \\
\text { de Artes }\end{array}$ & $\begin{array}{c}\text { R. Arroio } \\
\text { Grande, } 40 \\
\text { Ipiranga } \\
\text { Tel } 69142340 .\end{array}$ & $\begin{array}{c}\mathrm{R} \$ 130,00 \\
\text { (duas vezes por } \\
\text { semana) }\end{array}$ & Walter & 12 alunos \\
\hline $\begin{array}{l}\text { 29. Aqui Jazz } \\
\text { Ateliê Musical }\end{array}$ & $\begin{array}{l}\text { R. Tuim, } 999 \\
\text { Moema } \\
\text { Tel } 50940852\end{array}$ & $\begin{array}{l}\mathrm{R} \$ 200,00 \\
\text { (uma vez por } \\
\text { semana) }\end{array}$ & $\begin{array}{l}\text { Profa. Sílvia. } \\
\text { A professora é argentina e } \\
\text { formou-se em Buenos Aires. }\end{array}$ & 5 alunas \\
\hline $\begin{array}{l}\text { 30. Sede Social } \\
\text { da Associação } \\
\text { Brasil } \\
\text { Parkinson }\end{array}$ & $\begin{array}{l}\text { Av. Bosque da } \\
\text { Saúde, } 1155 \\
\text { Tel } 25788177 \\
\text { e } \\
30884098 \\
\text { (c/ Luci após } \\
\text { 19h) }\end{array}$ & $\begin{array}{c}\text { 5aapós } 13 \mathrm{~h} 30 \text { e } \\
3^{\mathrm{a}} \text {. } \\
\text { O curso é grátis } \\
\text { e o material é } \\
\text { oferecido aos } \\
\text { alunos. As telas } \\
\text { são vendidas } \\
\text { em uma } \\
\text { exposição } \\
\text { anual. Os } \\
\text { alunos não } \\
\text { podem ficar } \\
\text { com elas } \\
\text { (somente } \\
\text { quando as } \\
\text { compram). }\end{array}$ & $\begin{array}{l}\text { Luci Araújo (coordenadora) } \\
\text { Trata-se de uma entidade } \\
\text { filantrópica. O } \\
\text { freqüentador tem que ser } \\
\text { portador do Mal de } \\
\text { Parkinson. }\end{array}$ & 45 alunas \\
\hline
\end{tabular}




\begin{tabular}{|c|c|c|c|c|}
\hline $\begin{array}{l}\text { 31. Marcos } \\
\text { Rossi }\end{array}$ & R. Pamplona & $\begin{array}{l}4^{\mathrm{a}} \text { à noite } \\
\mathrm{R} \$ 120,00\end{array}$ & $\begin{array}{l}\text { É graduado em Direito e teve } \\
\text { sua formação em arte com } \\
\text { outro artista. O prof. também } \\
\text { dá aula no espaço do } \\
\text { Cultural Blue Life. }\end{array}$ & 6 alunos \\
\hline $\begin{array}{l}\text { 32. Instituto } \\
\text { Tomie Ohtake }\end{array}$ & $\begin{array}{l}\text { Av Brig. Faria } \\
\text { Lima, } 201 \\
\text { Tel } 22451900\end{array}$ & $\begin{array}{c}2^{\mathrm{a}} \text { das } 18 \mathrm{~h} 30 \text { às } \\
21 \mathrm{~h} 30 \\
\mathrm{R} \$ 150,00 \\
\text { mensais }\end{array}$ & $\begin{array}{l}\text { Existem vários cursos, mas } \\
\text { entrevistei o do Fernando } \\
\text { Vilela, ele é bacharel em } \\
\text { Artes Plásticas pela } \\
\text { Universidade Estadual de } \\
\text { Campinas. }\end{array}$ & 12 alunos \\
\hline $\begin{array}{l}\text { 33. Cultural } \\
\text { Blue Life }\end{array}$ & $\begin{array}{c}\text { Av. Brasil, } 298 \\
\text { Jardins } \\
\text { Tel } 38849084 \mathrm{e} \\
38846733\end{array}$ & $\begin{array}{c}4^{\mathrm{a}} \text { à tarde e } 5^{\mathrm{a}} \text { à } \\
\text { noite Prof. } \\
\text { Marco Rossi } \\
\text { R } \$ 160,00 \\
\text { Tel } 32841258 \\
\\
2^{\mathrm{a}} \text { à tarde e } 3^{\mathrm{a}} \text { à } \\
\text { tarde e à noite } \\
\text { Profa. Camila } \\
\text { Camargo } \\
\text { R } \$ 100,00 \\
\text { Tel } 55221768 \\
\text { e } 56869116\end{array}$ & $\begin{array}{l}\text { Os professores não são } \\
\text { graduados. }\end{array}$ & 15 alunos \\
\hline
\end{tabular}

Detalhando os itens deste mapeamento/quadro inicial, no cenário das práticas podem ser interpretados alguns aspectos físicos (visuais, táteis e sonoros); interação entre alunos (na perspectiva de Goffman ${ }^{53}$ ); perfil dos professores; os prospectos de divulgação dos cursos, além de idéias colhidas em entrevistas com coordenadores e donos das escolas. Compreende-se por cenário todo conjunto orgânico que envolve e é também construído pelas práticas. As práticas dos amadores estão impregnadas de influências das diferentes

\footnotetext{
${ }^{53}$ Goffman utiliza a metáfora do teatro, a interação entre atores e relação com público e cenário, e faz uma leitura do comportamento humano a partir de sua interação com uma determinada situação social. Baseando nele empregou-se nessa tese o termo "cenário" para falar das escolas de pintura, considerando - se que o cenário está intrinsecamente relacionado ao texto e aos atores. Cf. a propósito GOFFMAN, E. A representação do eu na vida cotidiana, op. cit.
} 
arquiteturas das escolas, do perfil dos professores. O cenário, embora não seja determinante, é importante porque interfere na concepção de arte de seus freqüentadores. Afinal, os espaços que abrigam os cursos também arquitetam uma idéia de fazer arte, resultam de práticas anteriores, já que os espaços são modificados e transformados a partir das práticas e em interação com seus diferentes $u_{\text {sos }}{ }^{54}$, são também um exercício de formatividade..$^{55}$

Então, como ingredientes de um imaginário cultural, foram analisados os móveis e materiais oferecidos aos alunos, a música de fundo, o cheiro, o chá de ervas oferecido, o incenso, os livros presentes sobre as mesas, pinturas nas paredes, caixas com recortes de imagens e revistas no local ${ }^{56}$. E como deu-se preferência por analisar esses elementos dentro de seu conjunto, associou-se as práticas de pintura por semelhanças entre : escolas de grande porte, cursos de pintura oferecidos em ateliês de artistas, ateliês coletivos escolas, cursos em escolas de pequeno porte, cursos de pintura ministrados na casa dos professores.

Por outro lado, essa interpretação do cenário auxilia a contraposição ou justaposição com algumas práticas, que, desajustadas, não correspondem às idéias evocadas pelo cenário.

\subsection{Primeiro Cenário: As escolas de grande porte}

As escolas de grande porte possuem um cenário bastante comum: espaços

\footnotetext{
${ }^{54}$ MAGNANI, J. G. C.; TORRES, L. de L. (orgs.). Na metrópole: textos de antropologia urbana. São Paulo: Edusp/Fapesp, 1996, p. 37.

${ }^{55}$ A teoria da formatividade é apresentada no subitem: Arte como Conhecimento, no capítulo III desta tese. PAREYSON, L. op. cit.

${ }^{56}$ Difícil negar a influência do ensaio de Bourdieu (2002), em que, com base nas fotos dos costureiros em suas maison, Bourdieu consegue interpretar um conjunto de comportamentos que compõem o capital simbólico deles.
} 
arquitetônicos que sugerem amplitude visual. A sensação de infinito é sugerida pela quantidade de branco: nas paredes e nos móveis. O ambiente "artístico" se caracteriza por uma decoração sutil e perspicaz, quase invisível. Respiram a atmosfera de uma arquitetura vanguardista ( $\mathrm{O}$ traço de Rui Ohtake no caso do Instituto Tomie Ohtake, e o de Niemeyer no caso do MAM). Um design sofisticado circunda os alunos: as estantes do ateliê do MAM, as portas assimétricas (e de correr) do Instituto Tomie Ohtake ou ainda as janelas do Collegio das Artes são exemplos disto.

Nestes locais, pode-se pintar em grandes mesas brancas ou então em lonas presas nas paredes. Sobre as mesas ou estantes vêem-se livros e catálogos de artistas e exposições atuais. Artistas do período inicial do modernismo artístico europeu aparecem menos nestes cursos (embora agradem aos alunos). A decoração destas escolas de pintura lembra os espaços que seus alunos costumam freqüentar: o espaço dos cursos do MAM e do Collegio das Artes remetem ao Cubo Branco ${ }^{57}$, os espaços oficiais de exposição de arte contemporânea. Também o silêncio dos museus está aqui presente: as conversas entre os alunos são em volume baixo e de conteúdo cultural (um livro, um filme etc.), às vezes, uma receita da culinária internacional. Sem opulência, estas escolas possuem uma atmosfera refinada.

É interessante perceber que estas escolas, onde mais se apregoa uma arte legitimada como "contemporânea", são justamente as escolas com mensalidades mais caras, freqüentadas por um público de estrato social maior. No Collegio das Artes os alunos são freqüentadores de museus e galerias. Lembra-se que Pierre Bourdieu constata que a partir do momento em que a arte passa a ser o seu próprio objeto de reflexão, a

\footnotetext{
${ }^{57} \mathrm{O}$ termo cubo branco é utilizado como uma referência aos locais de exposição de arte moderna que pretendem isolar o trabalho de arte através da arquitetura de um espaço que crie uma percepção ascética. Muitos artistas já desenvolveram obras feitas exclusivamente para comentar ou criticar esse espaço, que se assemelha a um cubo branco. Cf. O'DOHERTY, B. No interior do cubo branco: a ideologia do espaço da arte. São Paulo: Martins Fontes, 2002.

${ }^{58}$ BOURDIEU. P. Creencia artística y bienes simbólicos: elementos para uma sociología de la cultura, op. cit., p. 32 .
} 
partir das vanguardas, ela começa a ser consumida por um público de estrato social mais elevado ${ }^{58}$.

Nos trabalhos que os alunos produzem nota-se que não há preocupação com a verossimilhança, e as pinturas radicalmente abstratas parecem mais um exercício formal, uma discussão sobre forma, cor, suporte e gestualidade.

Os alunos são profissionais liberais, psicólogos, arquitetos, veterinários, professores do ensino superior (de Arqueologia, História), jovens interessados. Ainda com uma maioria de mulheres, alguns homens se fazem também presentes. É interessante notar, ainda, tanto na publicidade destes cursos quanto nos prospectos de divulgação a simplicidade de formas: poucas cores, uma única tipologia de letra, prospectos visualmente econômicos, mas ao mesmo tempo ousados, como o caso do prospecto do Museu de Arte Moderna de São Paulo - MAM - SP. Aqui, para atrair alunos a publicidade não é fundamental. A atual proprietária do Collegio das Artes, Saleti Barreto de Abreu, foi também coordenadora dos cursos livres do Museu Brasileiro de Escultura - MUBE e do MAM SP e tem uma boa idéia sobre o perfil dos alunos que freqüentam esses cursos. Segundo ela, embora exista variedade, a maioria deles são parte de um público que visita museus e que gostariam de se aproximar mais daquele universo:

"Os cursos livres que eu comecei a desenvolver mesmo
começaram em 1980 no MAM. Que eu descobri que tinha um
público que estava começando a ter um interesse maior pela
arte, e era realmente um público que de uma forma ou de
outra visitava museus, tinha interesse e pensava: - Olha, você
colecionar arte... como poderia? Enfim, existia certa
curiosidade desse público que acaba tendo um interesse maior
[...] ele gosta de um artista, de um trabalho e pensa em como
poder chegar até esse artista. Se for um artista jovem,
contemporâneo, ele se aproxima via curso livre, começa na
pintura, no desenho para entender melhor a linguagem e
compreender por que o artista se expressou desta maneira." 59

\footnotetext{
${ }^{59}$ Trecho transcrito de entrevista feita com Saleti Barreto para esta pesquisa.
} 
As pessoas que se aproximam destes cursos já possuem um contato com artistas ou com a arte dos museus que freqüentam, procurando nos cursos um aperfeiçoamento, uma forma de se aproximarem mais dessa arte. Porém, muitos desses alunos buscam fazer uma atividade que os distancie do mundo do trabalho, e fazem arte como lazer.

Tudo isso indicia a compreensão de como o consumo de arte não é ordenado ${ }^{60}$ e permite operações piratas ou "trajetórias indeterminadas" ${ }^{61}$. Neste grupo por exemplo, observou-se alunos de pintura com concepções diferentes de arte das construídas ou propostas pelo cenário. Por exemplo, no curso do MAM, uma das alunas pintava um quadro com um padrão que era o mesmo de seu sofá, destinado à decoração de sua casa. Neste contexto, na aula do professor Sérgio Niculitcheff, que é um artista contemporâneo, lecionando dentro de um museu de arte moderna, poder-se-ia interpretar esta pintura como uma pesquisa formalista, por exemplo na linha da artista feminista canadense Miriam Schapiro, ou ainda das brasileiras Mônica Nador, Lia Menna Barreto ou Leda Catunda, ou qualquer outro trabalho do movimento pattern painting ${ }^{62}$. No entanto, ao se escutar a fala da aluna, descobria-se que a aluna não estava pensando "a temática feminina" ou refletindo sobre os trabalhos "ditos da manualidade feminina" na arte, ela estava pintando algo que seria útil para a sua casa, para a decoração, que devia ser outro exercício de formatividade do qual ela gostava. Neste exemplo, observa-se que o cenário (dos cursos) nem sempre determina a prática ou a concepção de arte de seus freqüentadores. E nestes casos, essas trajetórias, podem ser interpretadas como táticas, que são ações que ocorrem a partir de um não-lugar, são movimentos e formas de agir que se mobilizam dentro de um campo do outro. A tática, como define De Certeau, é “a arte de dar golpes no campo do outro ${ }^{63}$ ".

\footnotetext{
${ }^{60}$ Associação ao termo "consumidores" de Michel de Certeau.

${ }^{61}$ CERTEAU, M. de. op. cit., p. 104.

${ }^{62} \mathrm{O}$ movimento pattern painting surgiu em 1975, em Nova York, e promoveu uma reflexão sobre o trabalho artesanal e repensou algumas práticas designadas "femininas".

${ }^{63}$ CERTEAU, M. de. op. cit., p. 104.
} 
NARRATIVA VISUAL 1: Cursos de pintura em escolas de grande porte.

Instituto Tomie Ohtake
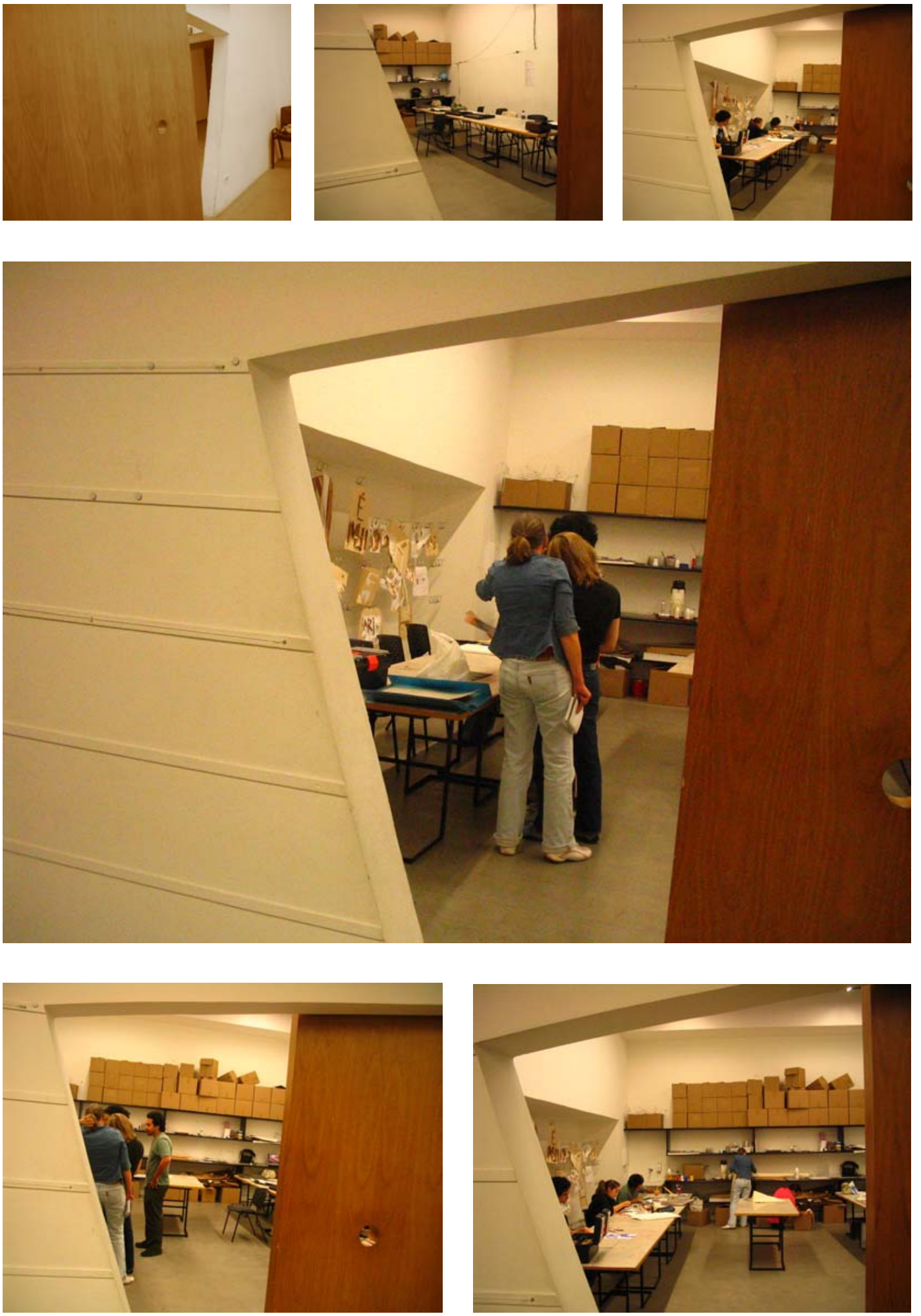

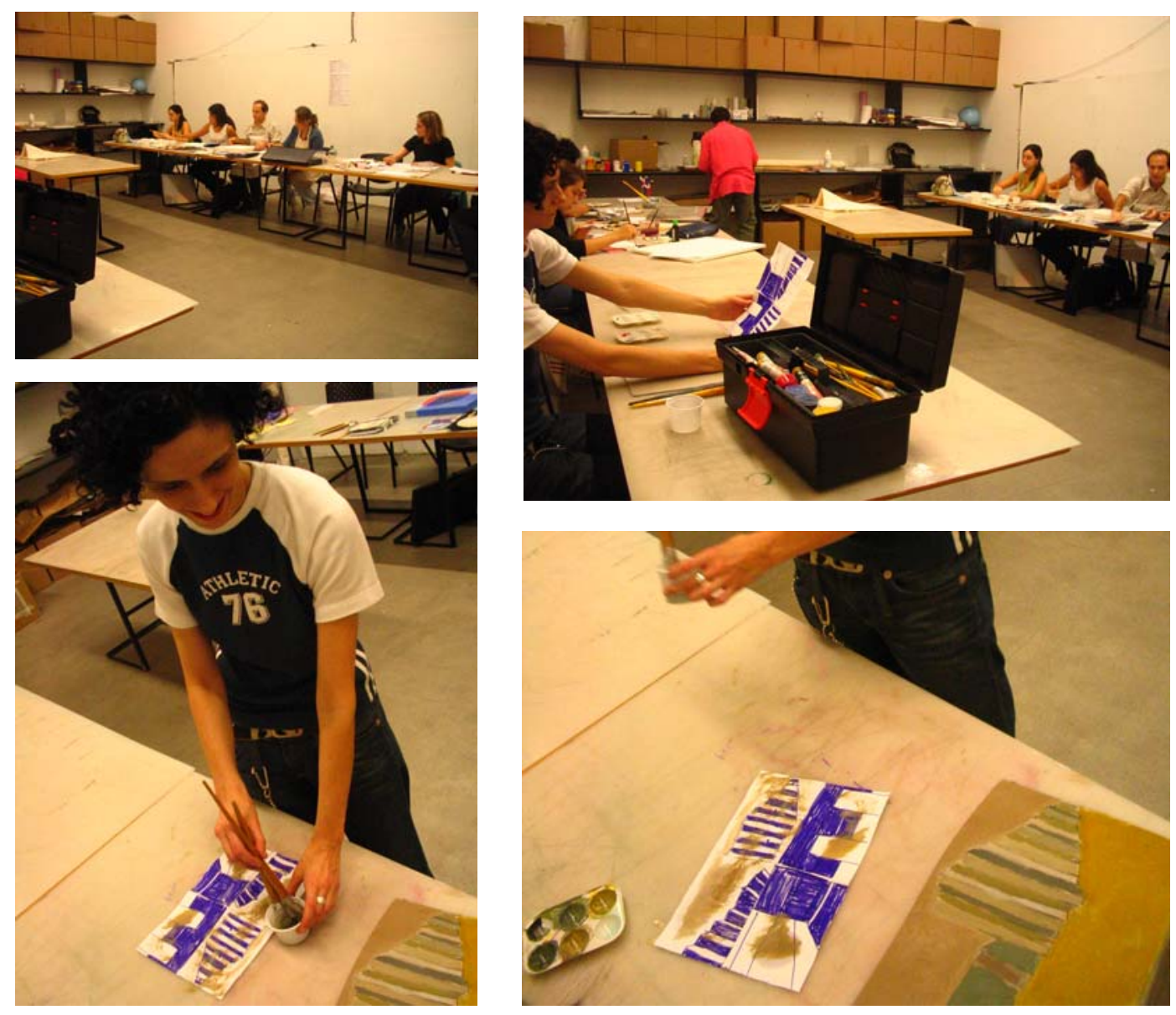

Collegio das Artes

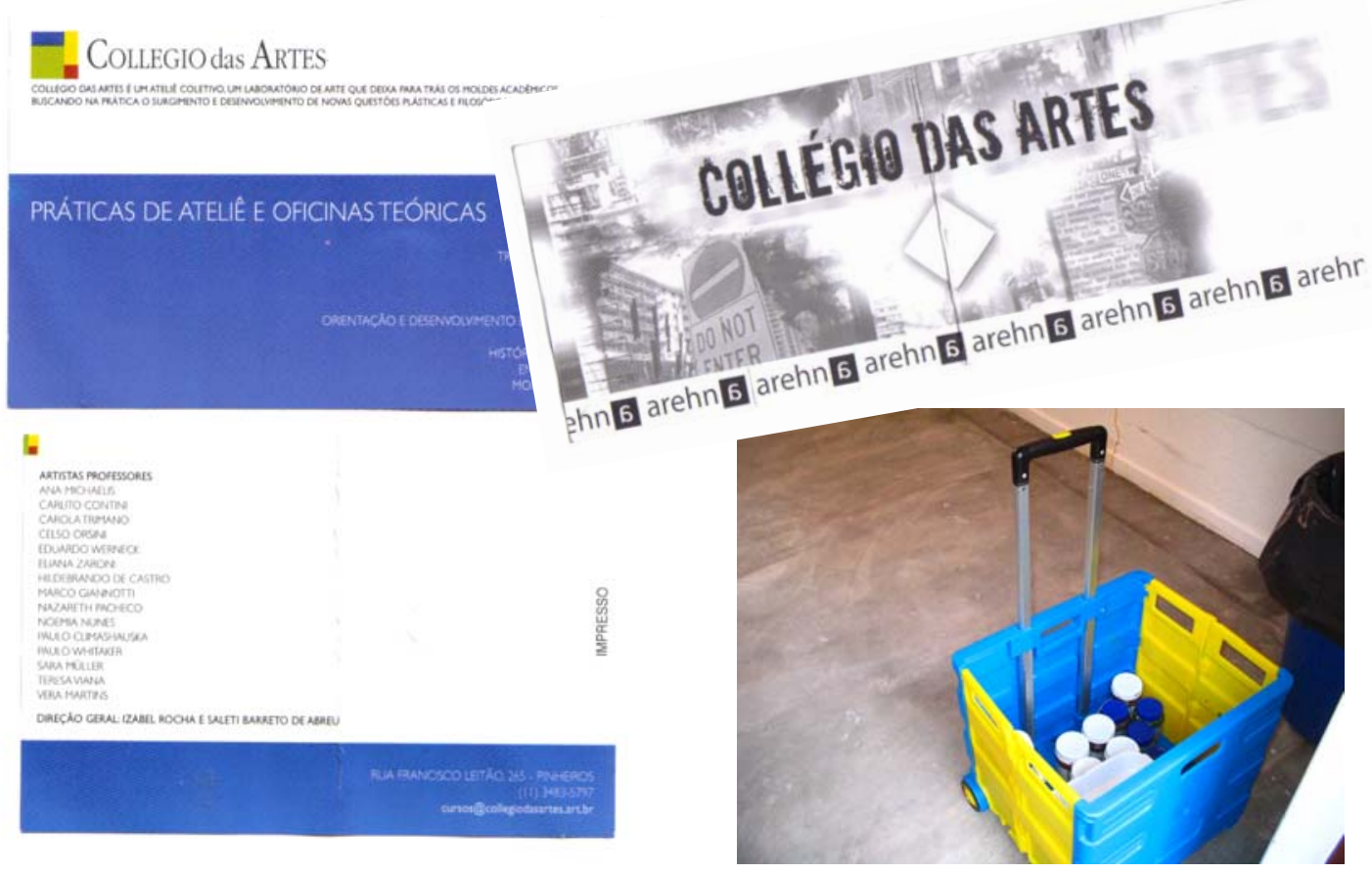




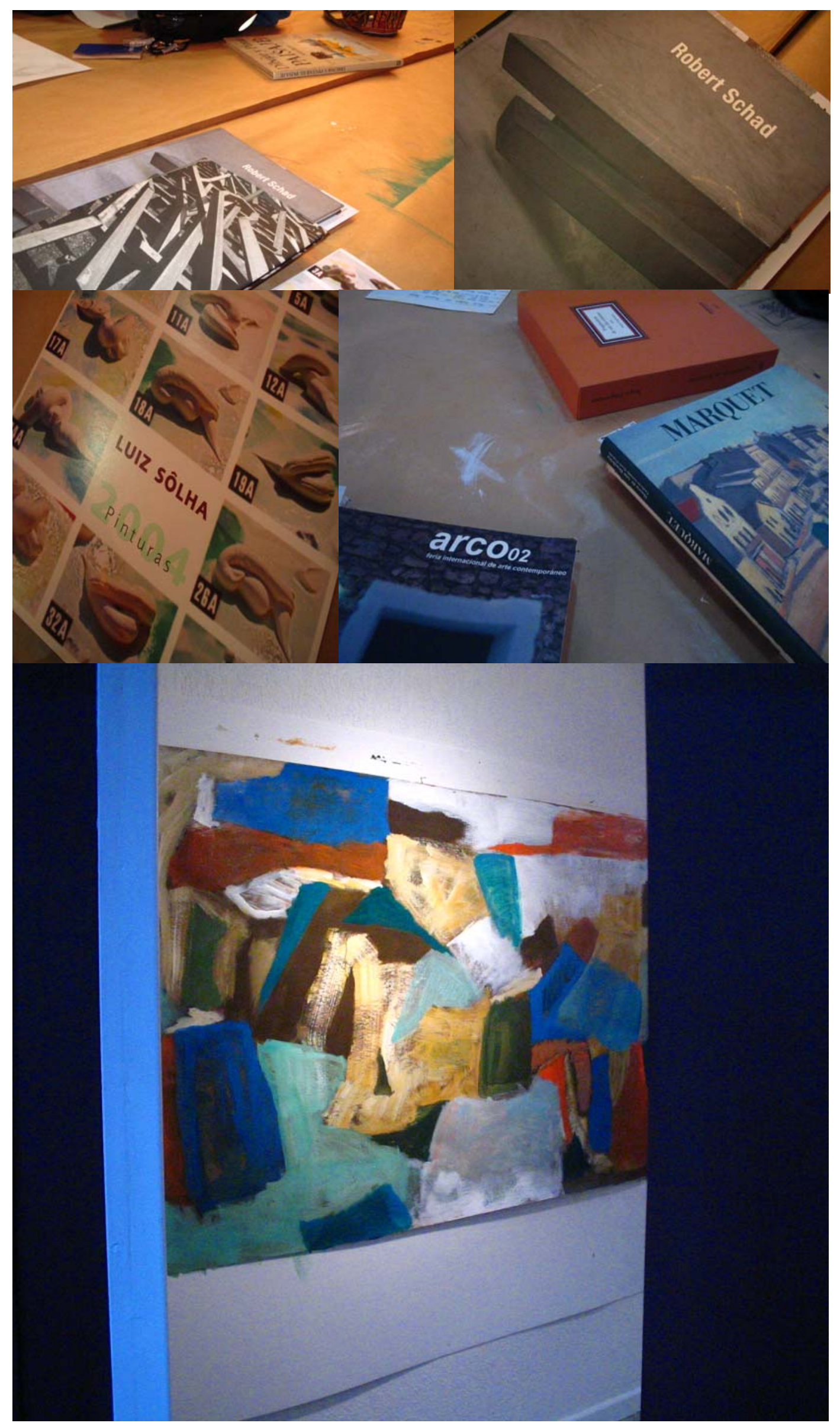



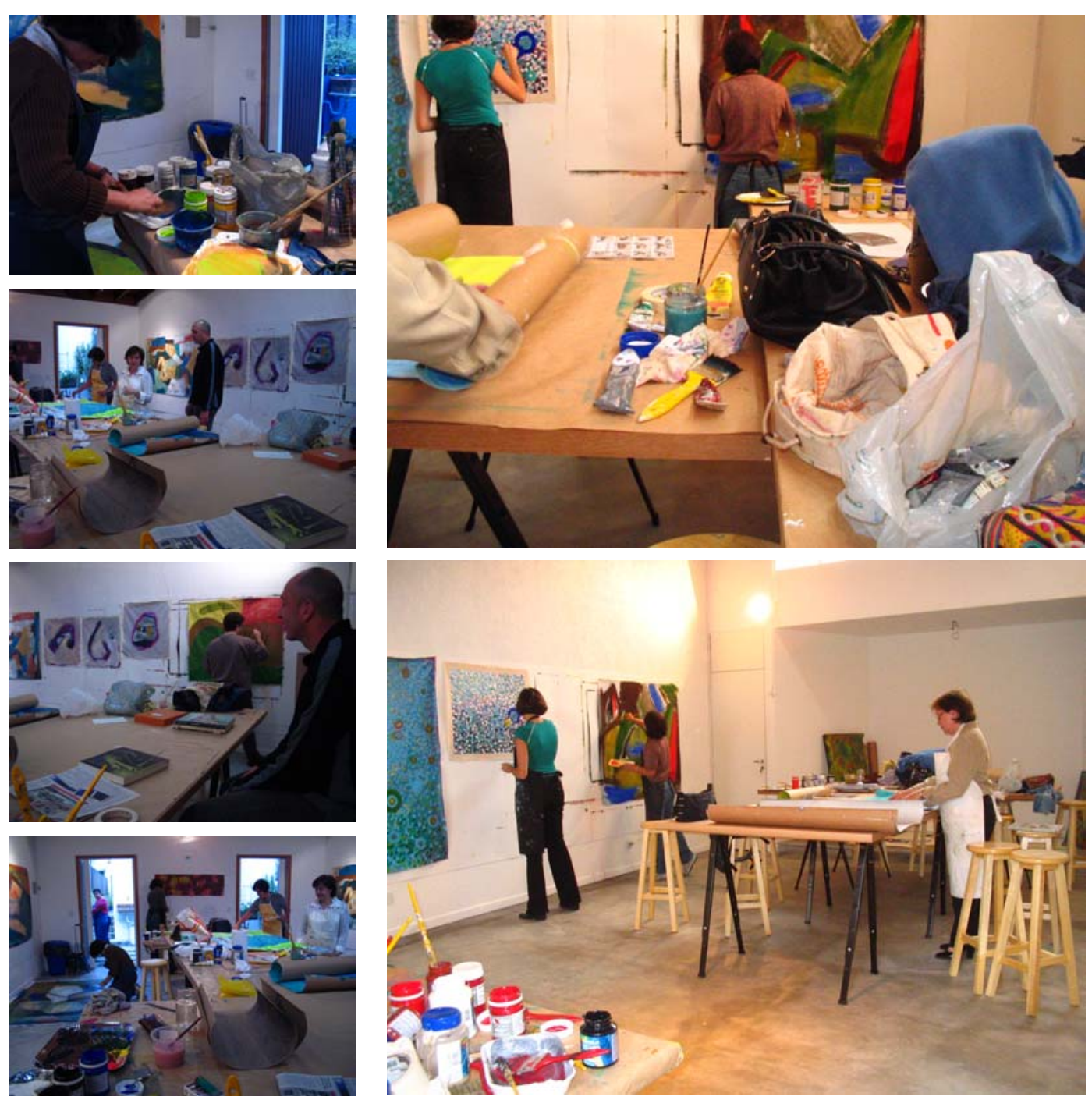

Museu de Arte Moderna de São Paulo - MAM/ SP

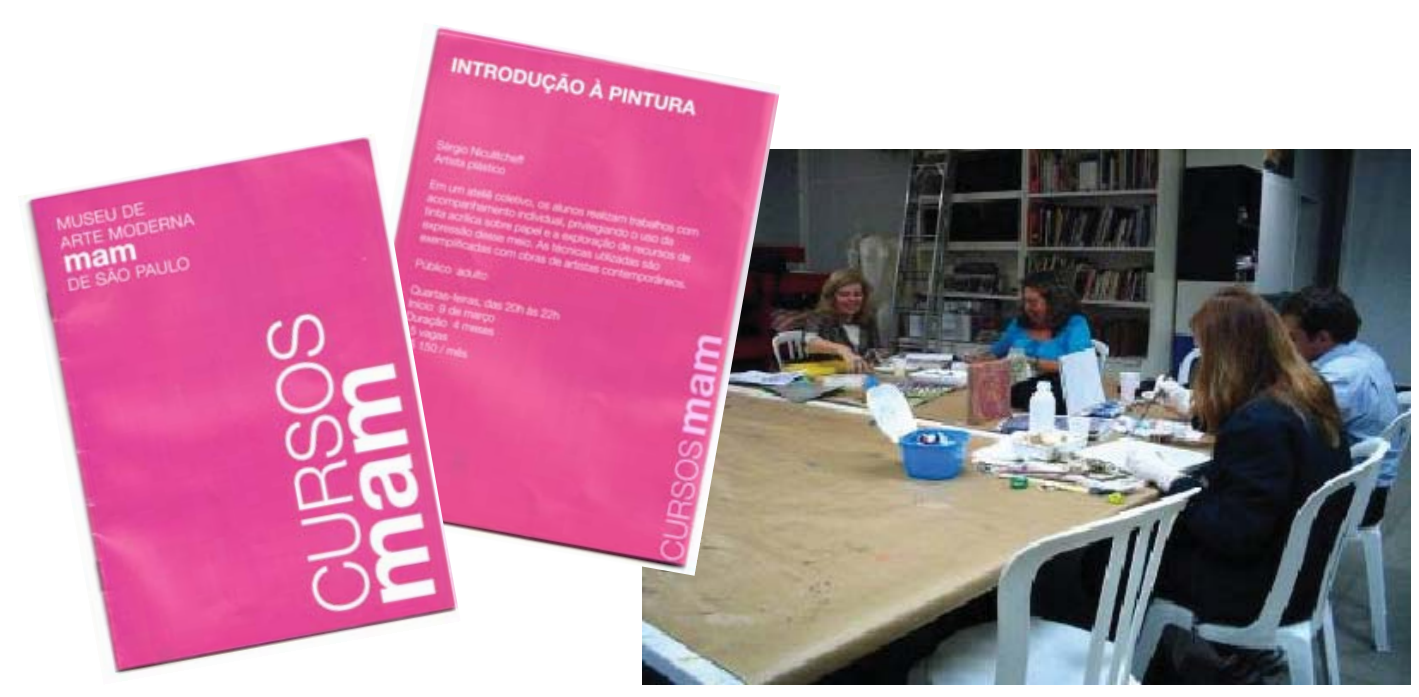


Delta Ateliê de Artes
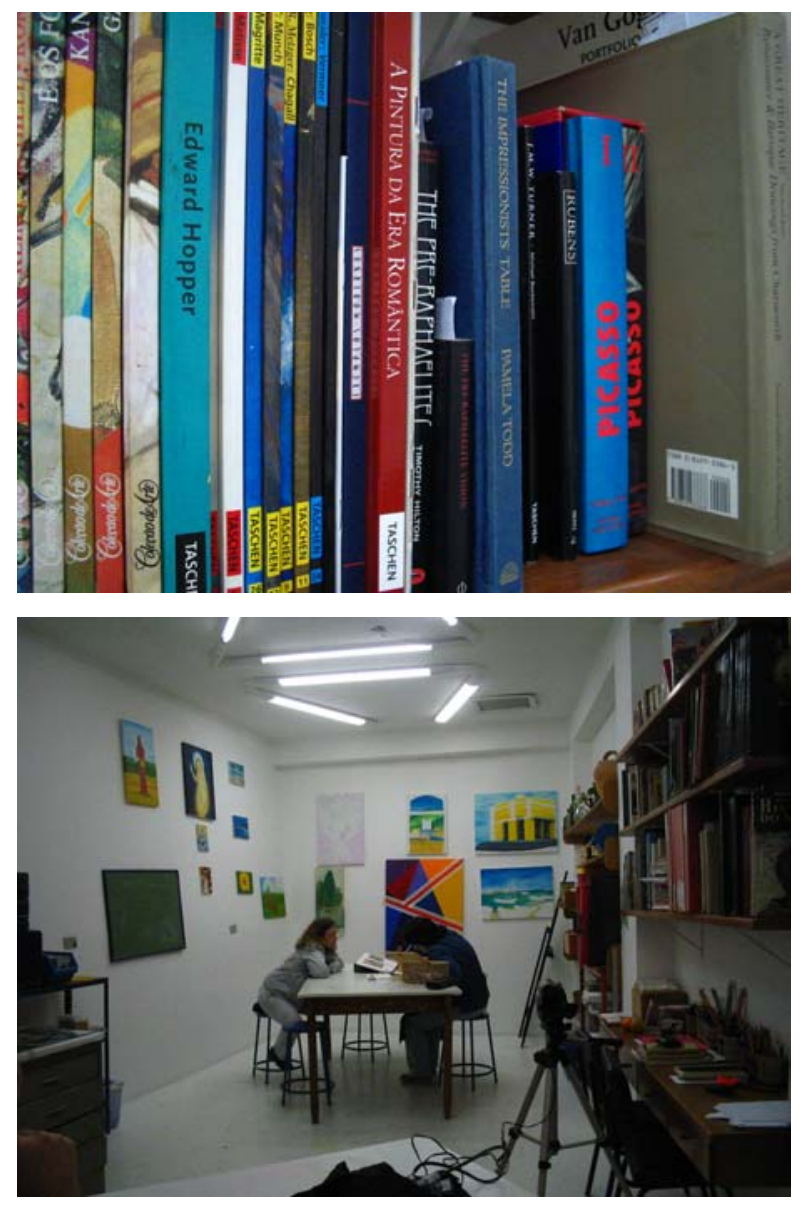

O que poderemos ver em 2005

Unoorr, maio - Expoente da escultura modema.o inglés Henry Moc

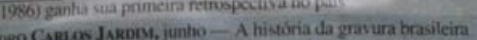
ano Carjos Jakons, junho - A hisória da grasura brasilein

onsuccan, jultho - Ao Lado de Volpi e Rebolo, entre outros coleg crm isaliana foi um dos integrantes, nos anos 30 , do Grupo Santa Hele

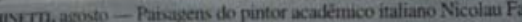
Yocoi, gue se fixou no Brasil

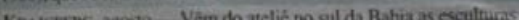

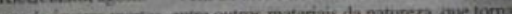
nts Kraicherg unica e original

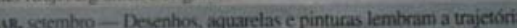
uncr do varrealiomo argentino Xul Solar (1887-1963)

rus Vulu ea Vius Kvkiu, novembro - O mecenas da belle éf fistana José de Freitas Valle (1870-1958) e seus agitos culturais na ch. a Mariana so objeto dessa mostra

Eusua - Outro arpentivo no calendínio. Ferrari, 84 anok marcou 2

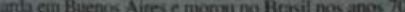
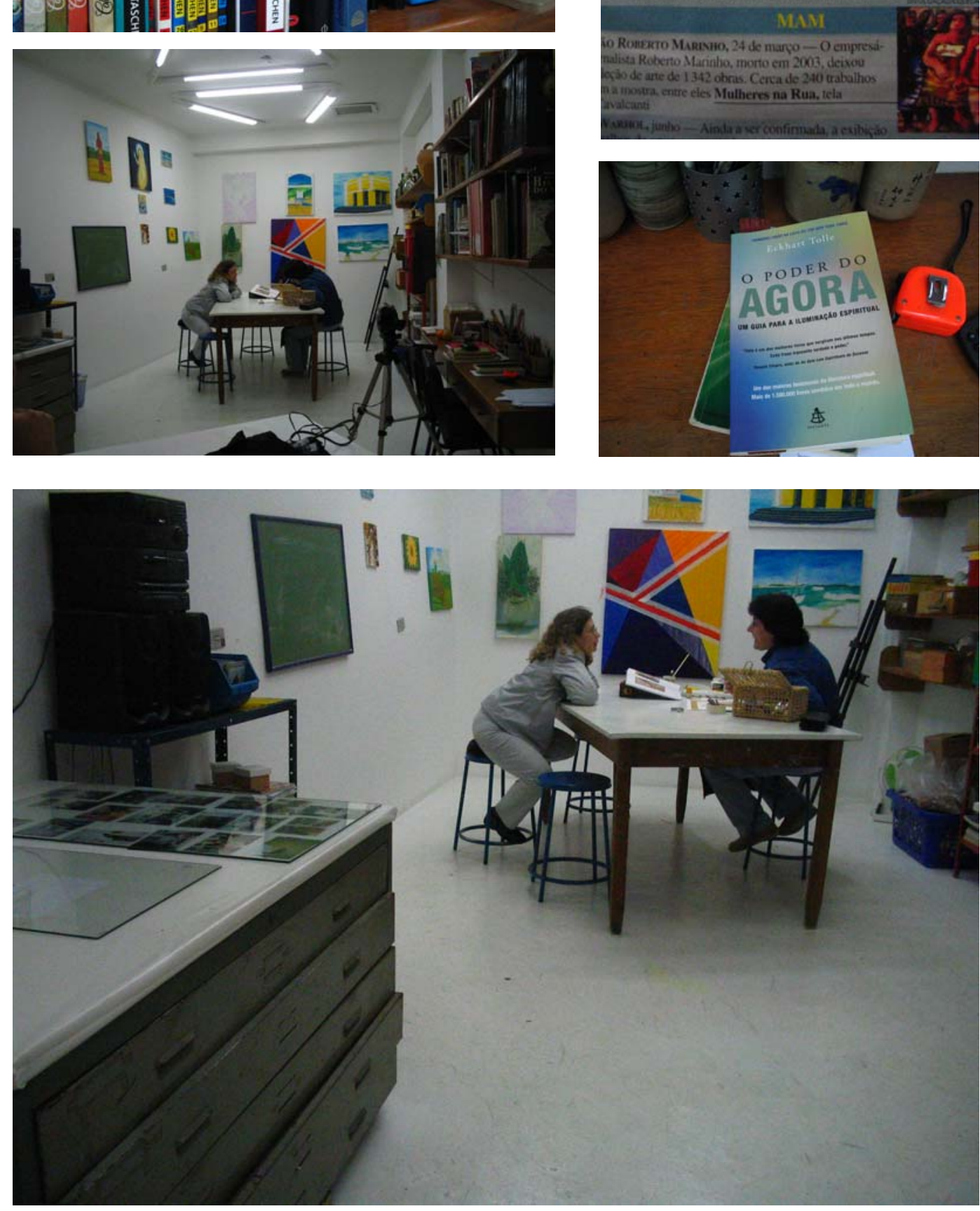


\subsection{Segundo Cenário: Cursos de pintura oferecidos nos ateliês dos artistas.}

O espaço do ateliê coloca os alunos em contato com o processo artístico, dentro do espaço de criação. O ateliê permite ver o artista em processo: seus desenhos inacabados, idéias em suspensão, suas dúvidas, pinturas mais antigas e mais recentes, obras embaladas, seus catálogos e tudo mais que um ateliê de pintor oferece. Os ateliês visitados, mesmo muito diferentes entre si, são espaços privilegiados para qualquer aprendiz. O professor, por estar dentro do seu espaço de trabalho, tem seu papel de artista mais evidente. É difícil estar num local como esse sem tematizar as questões intrínsecas ao trabalho do artista. Foram visitados os ateliês-escola de Teresa Viana, Israel Kislansky, Rubens Espírito Santo e Jaqueline Arônis.

O ateliê-escola de Teresa Viana ocupa um grande galpão e suas coloridas e enormes telas, encostadas em praticamente todas as paredes, recebem uma iluminação natural pela manhã. Um cheiro de tinta domina o espaço, que se abre para um silencioso pátio interno. Embora Teresa tenha apontado o perigo que a influência de sua obra poderia exercer sobre suas alunas, nenhuma aluna estava fazendo nada parecido. Teresa prepara com antecedência o espaço para sua aula, instalando mesas, bancadas sobre cavaletes e cobrindo suas telas. Teresa não tem prospecto de divulgação e não promete resultados breves. A artista, com seu atendimento individual, responde a diferentes objetivos e desejos dos seus alunos.

$\mathrm{O}$ ateliê de Jaqueline Aronis fica dentro de uma charmosa vila, que parece européia, numa das regiões mais valorizadas de São Paulo: Higienópolis. Por dentro, seu ateliê lembra uma galeria contemporânea, com móveis predominantemente brancos, parece com as escolas de grande porte. Num fundo alvo, destacam-se lápis coloridos cuidadosamente arrumados e apontados, conchas e outros objetos de texturas curiosas. Uma luz branca e uma organização mais geométrica dão ao ateliê um aspecto asséptico, racional. Como o ateliê de Teresa, o local também é muito silencioso. Os alunos se acomodam em torno de uma enorme mesa, que fica na primeira sala do ateliê. 
Esses ateliês, diversificados, são muito ricos de imagens. Por isso, a simples visita a esses espaços já é educativa. O ateliê Kislansky é atípico por estar no mesmo prédio onde vivem o próprio artista com sua família e também seus funcionários. Paredes ocre, peças de alunos, modelos (que posam) e auxiliares circulam por entre escadas e corredores: esse espaço lembra uma guilda medieval ou um ateliê comunitário do final do século XIX. Encontrar um ateliê-escola como este em São Paulo abre uma sutura temporal, deliciosamente desarmônica e dissonante. Enquanto Kislansky orienta a oficina de modelo vivo também desenha. No intervalo das aulas, trabalha em suas peças e organiza exposições. Discute sua vida profissional com os alunos e ao mesmo tempo em que se faz presente como orientador, desmistifica o trabalho do artista. Predominantemente um escultor, suas peças e moldes estão em todos os espaços, por vezes ao lado de peças de alunos.

Com forte trabalho a partir da figura humana, a pesquisa dos alunos também circunda a figuração. Mesmo a aula de pintura e desenho é a partir de modelo vivo. O ateliê-escola possui uma estrutura muito organizada de cursos práticos, palestras teóricas e também produz um jornal. Israel lançou um livro sobre seu ateliê, onde estão expostas suas idéias em relação à arte figurativa. É esclarecedor citar aqui um trecho deste livro, que expõe com muita clareza a opção de Israel em trabalhar com uma obra essencialmente figurativa:

Eu acho que sempre existirá uma oficialidade. E de fato hoje em dia a arte oficial é chamada arte contemporânea [...]. Refiro-me ao que se estabeleceu historicamente [como] arte contemporânea, a partir de certo momento, com o intuito de diferenciar a arte moderna da vanguarda. Essa arte contemporânea seria tudo aquilo que se produziu desde as décadas de 60 e 70 e esteve ligado quase sempre às posições duchampianas. No momento em que se estabelece que um aspecto da arte moderna deva prevalecer e que outros que vinham, pari passu, produzindo uma arte significativa e diversa, pertencem obrigatoriamente ao passado, você interrompe todo um processo que estava em plena floração $e$ que poderia continuar dando frutos importantes. No Brasil, 
tínhamos as obras de artistas como Portinari e De Fiori. Picasso ainda estava produzindo, sem falar em toda uma produção abstrata e concreta. Tudo isso poderia alimentar uma nova geração de artistas que estariam ligados a outra tradição - palavra demonizada - artística importante, ainda com fôlego para produzir novas questões. Mas quando se diz que a partir deste momento o que é válido, o que é vanguarda, será apenas um um dos caminhos que a modernidade encontrou, transforma-se todas as outras possibilidades em passado. Toda uma leva de artistas que vinham produzindo e influenciando outros artistas será, a partir dai, classificada como antiga, ou pior, ultrapassada. Qualquer artista que tenha sido influenciado por um Giacometti, por exemplo, não terá espaço para retrabalhar as possibilidades escultóricas propostas por esse artista, a não ser que ele releia Giacometti da forma adequada. Mas adequada a quê? A uma cartilha que é distribuida pela oficialidade? ${ }^{64}$

O depoimento de Kislansky é esclarecedor porque dá sentido ao seu ateliêescola. Sem ser uma opção ingênua, ou retrógrada, revela uma tomada de posição do artista, fundamentada pelas suas idéias sobre arte. Como explicita a fala de Kislansky: são contemporâneas uma diversidade de fazeres artísticos que insistentemente são apresentados como históricos.

\footnotetext{
${ }^{64}$ Entrevista com Israel em SQUEFF, E.; SIMÕES, E. Kislansky - o eterno e o moderno. São Paulo: Editora San Floro, 2006, p. 132-133.
} 
NARRATIVA VISUAL 2: Cursos de pintura oferecidos nos ateliês dos artistas

Ateliê Jaqueline Aronis
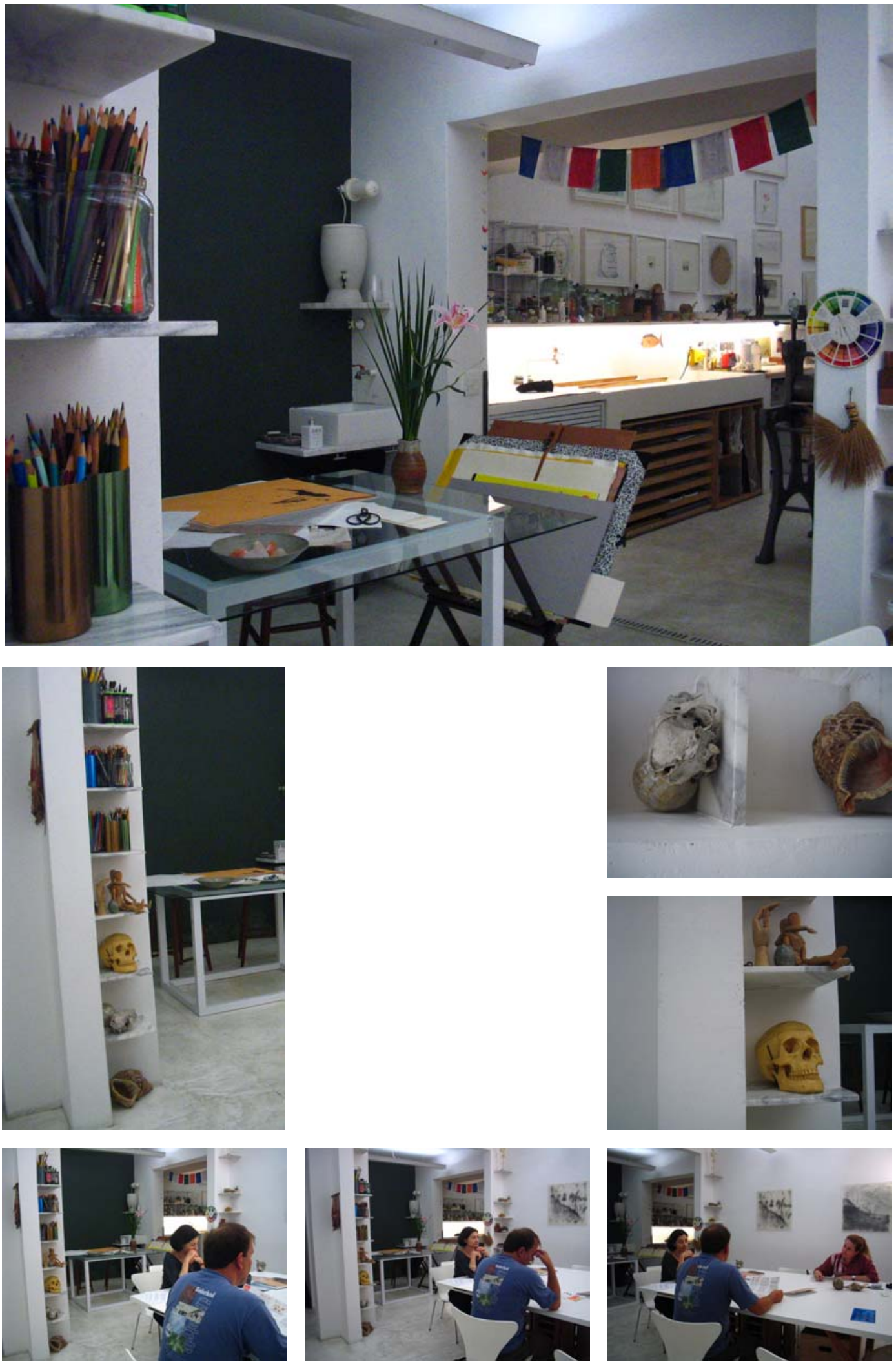
Kislansky Ateliê de Escultura
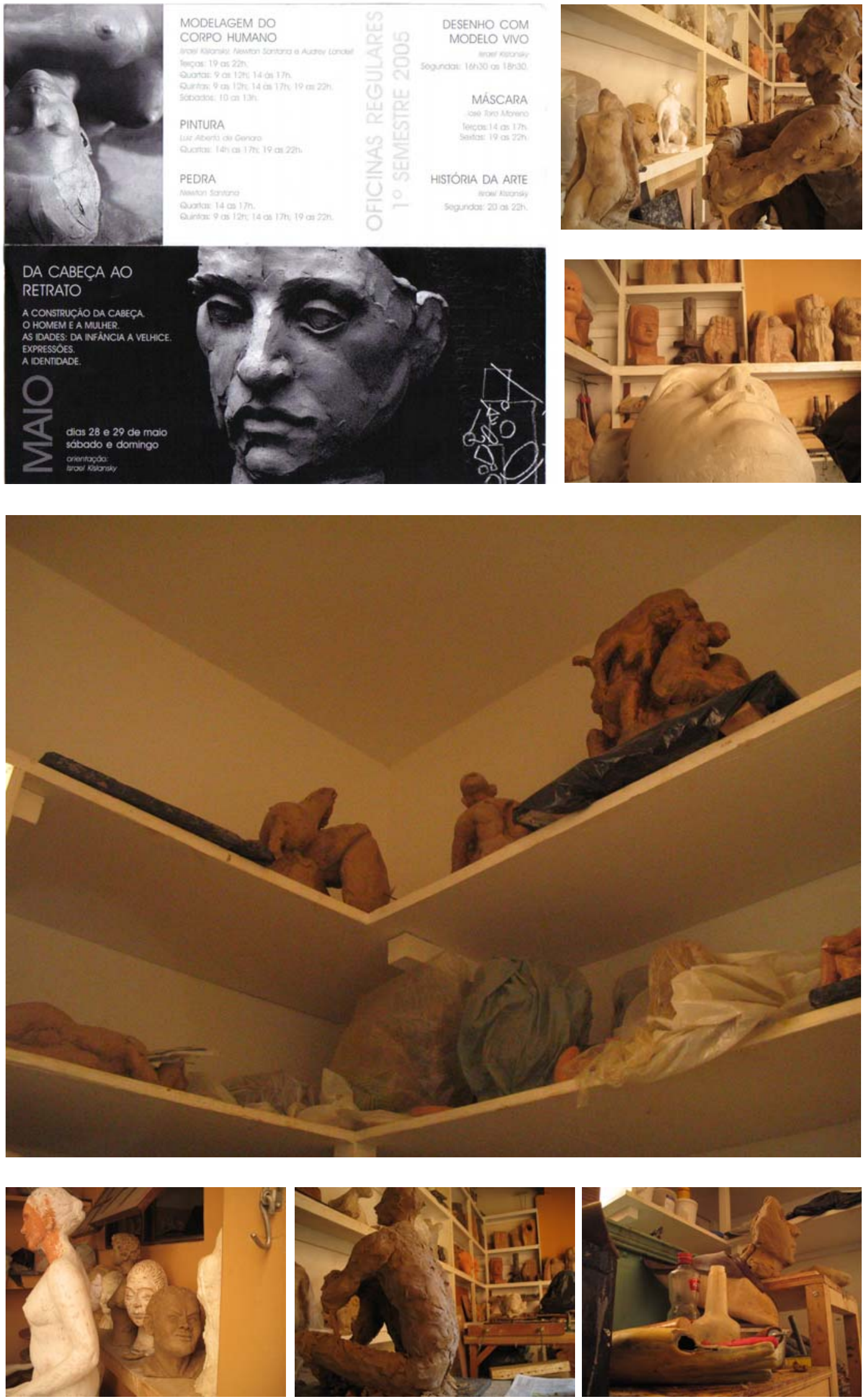

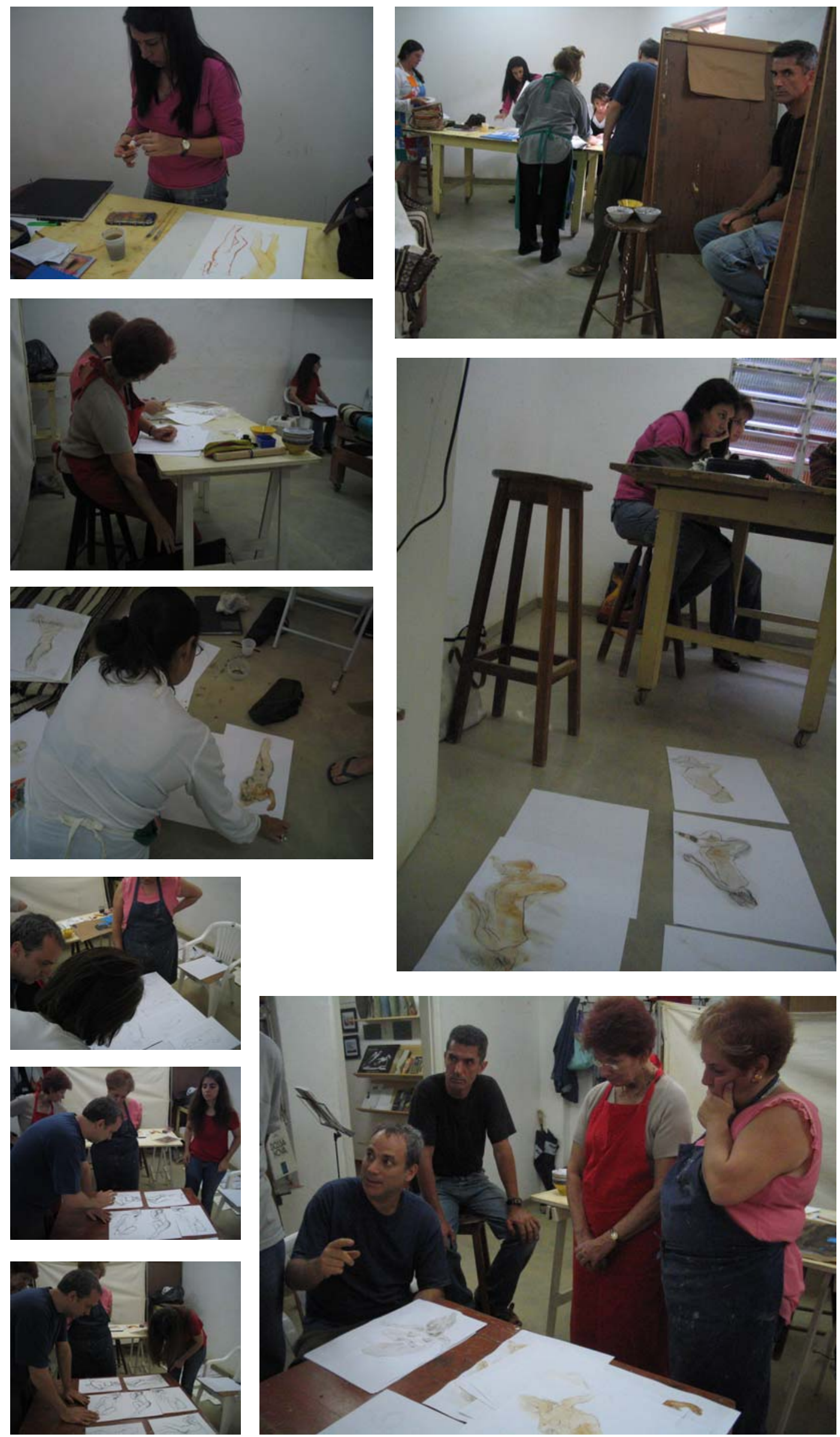

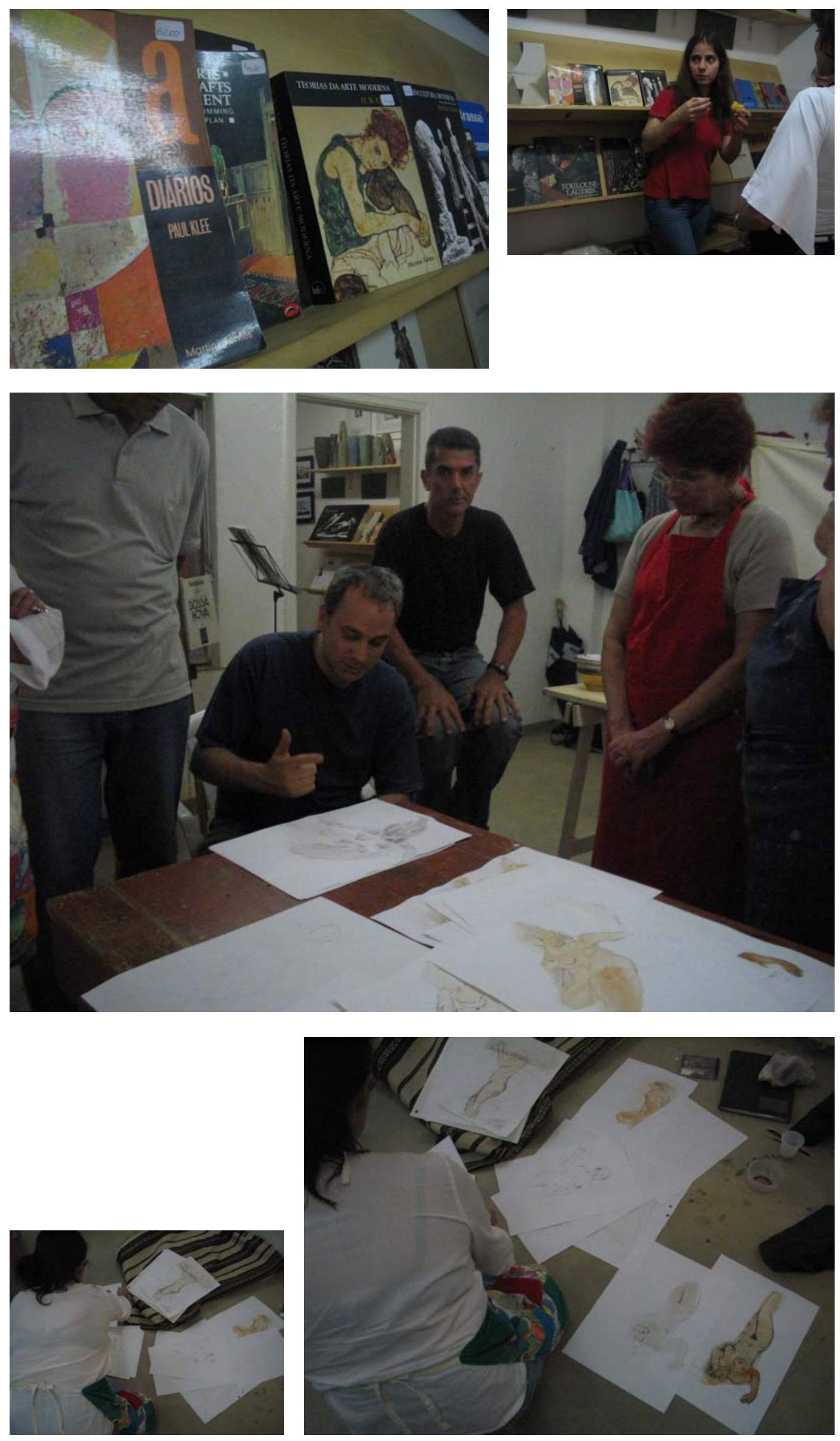
Ateliê Escola Teresa Viana
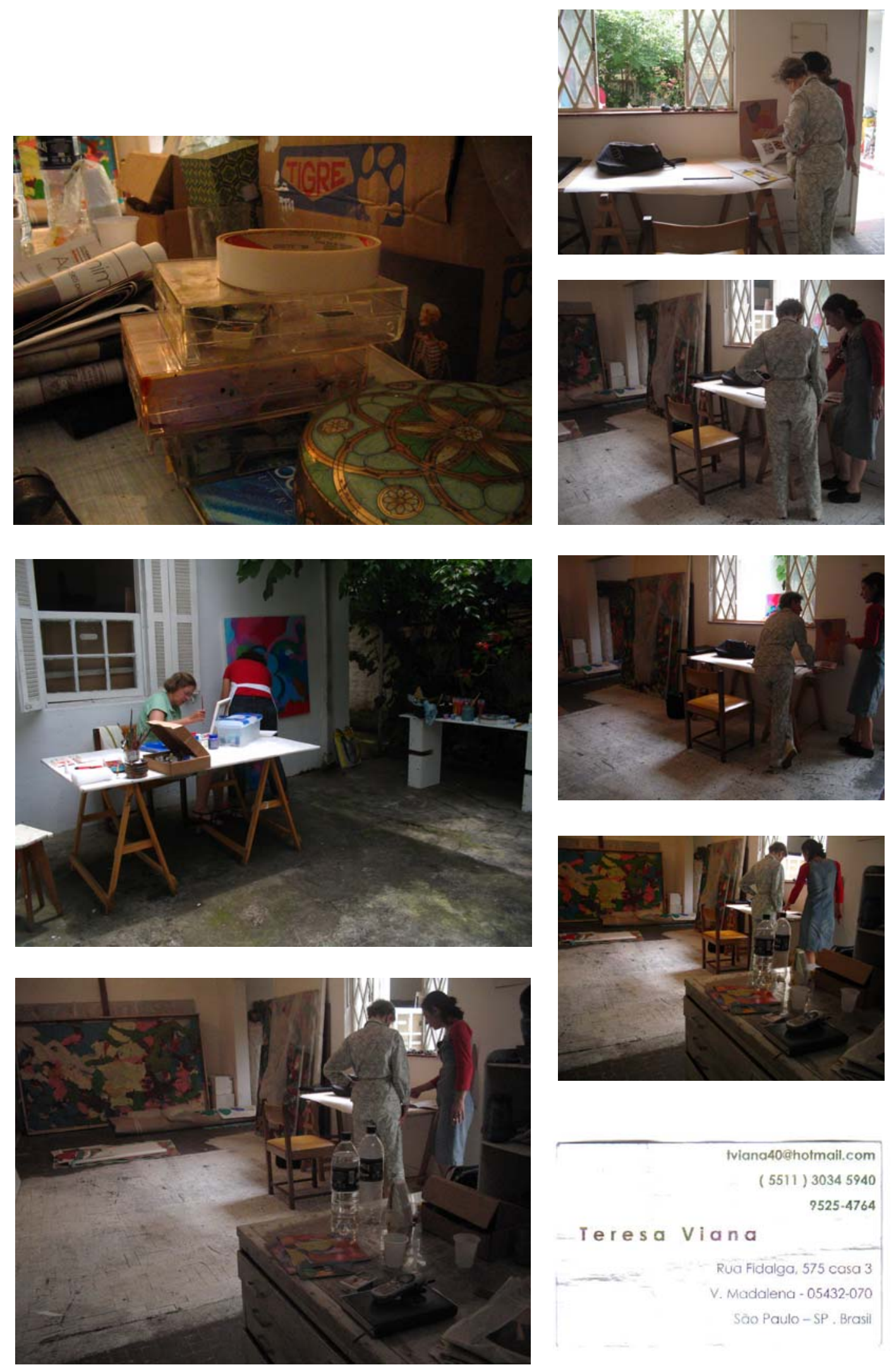

tviana40Ghotmail.com ( 5511$) 30345940$ $9525-4764$

Teresa Viana

Rua Fidalga, 575 casa 3

V. Madalena - 05432-070

São Paulo - SP. Brasil 


\subsection{Terceiro Cenário: os ateliês coletivos/escola}

Também existem ateliês coletivos que oferecem aulas de pintura, como é o caso do Ateliê Coringa e do ateliê de Rubem Espírito Santo (que ele chama Universidade Livre de Arte). Ambos são muito organizados em relação à dupla utilização como ateliê e como escola.

O Ateliê Coringa, por exemplo, possui um organizado site na internet, com todas as propostas de cursos e outras atividades. Vejamos um texto retirado desse site:

Espaço Coringa é um ateliê coletivo situado na Vila Madalena, em São Paulo. Nesse ateliê, desenvolvem-se diferentes atividades envolvendo criação artística (xilogravura, gravura em metal, pintura, desenho gráfico, vídeo) e educação. O Espaço Coringa é também um grupo de artistas que propõe trabalhos de arte para espaços públicos, intervenções urbanas, exposições de artes visuais, publicações e outros projetos aliando criação artística e atividades educativas. $O$ objetivo é aproximar as pessoas do processo de criação e execução do trabalho de arte e também congregar artistas para discutir questões relacionadas ao oficio, reunindo esforços para realização de projetos coletivos. ${ }^{65}$

Apesar de ter uma proposta de aproximação entre "pessoas" e o processo artístico, e de produzir trabalhos para espaços públicos, eles não compreendem ou vislumbram a possibilidade de existirem públicos com concepções de arte diferentes das suas. Matheus, um dos artistas e professores do espaço Coringa, em conversa inicial, afirmou que raramente aparecem alunos que querem pintar "marinhas" e acrescentou: quando aparecem, acabam fugindo na primeira aula. Pensando a proposta do ateliê (de

\footnotetext{
${ }^{65}$ Trecho de apresentação do espaço coringa <www.espacocoringa.com.br>. Acesso em 14/08/2005 (grifo nosso).
} 
aproximação e de propostas de trabalho educativo e para espaços públicos), pode-se refletir que afugentar os pintores de marinhas é uma ação bastante incoerente com a proposta “comunitária" anunciada. Também aqui se confirma a necessidade de distinção dentro do próprio campo, em que o gosto se define muito mais por uma repulsa ao que não se gosta do que por uma tomada de posição. A conversa com a comunidade é proposta partir de um ponto de vista determinado e determinante. Projetos que trabalham com essa junção: arte/educação/comunidade precisam questionar ou definir mais claramente qual arte, qual educação e qual comunidade a que se referem. As generalizações, nesse caso, refletem ingenuidade ou encobrem formas dissimuladas de discriminação cultural.

O espaço do ateliê coletivo organizado por Rubens Espírito Santo é compartilhado com diferentes artistas. Alternativo, está localizado no centro de São Paulo, em frente ao edifício Copan, numa área da cidade considerada "maldita". A Universidade Livre de Arte-ULA apresenta uma proposta de trabalho muito precisa, com uma concepção de arte muito clara e destinada a um determinado tipo de público.

\section{FIGURA 1: Prospecto Universidade Livre de Arte-ULA}
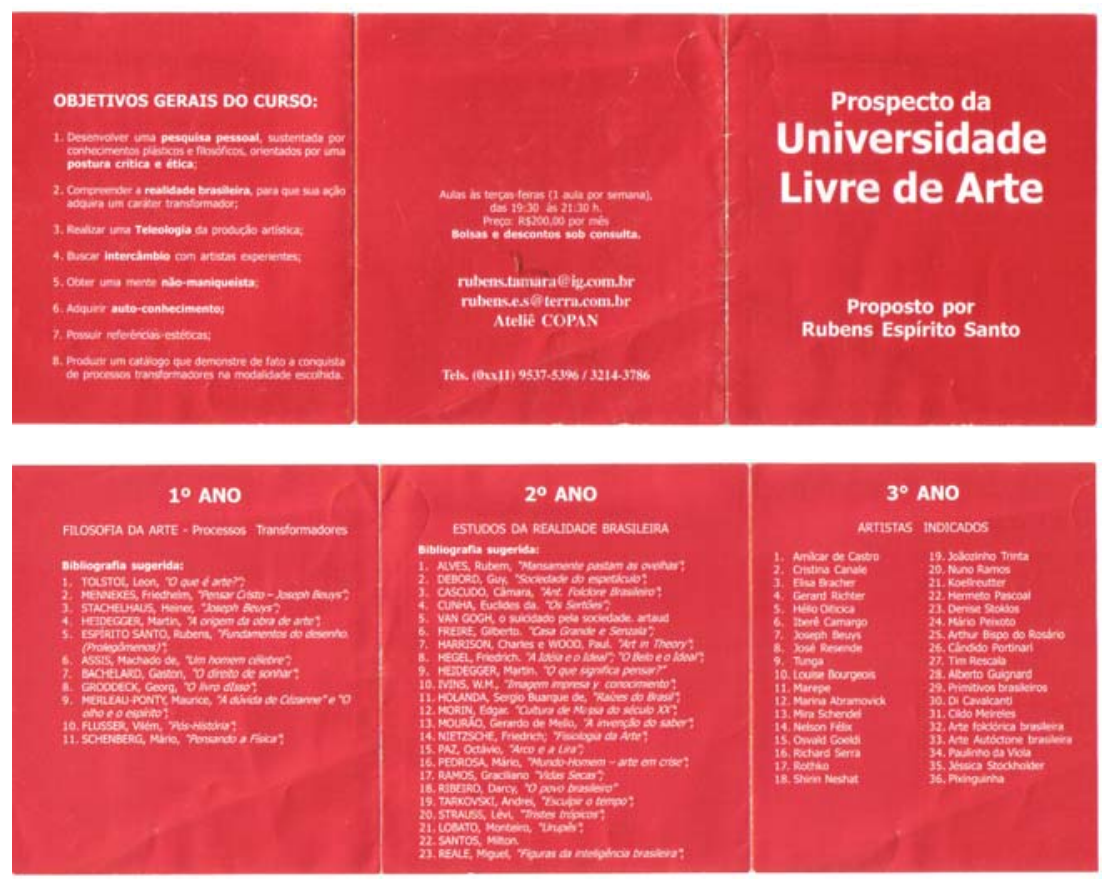
Com uma proposta de formação teórica de três anos, mostra os objetivos gerais do curso. Dentre estes: "Desenvolver uma pesquisa pessoal, sustentada por conhecimentos plásticos e filosóficos, orientados por uma postura crítica e ética" e "Buscar intercâmbio com artistas experientes". E outros bastantes amplos mesmo para um curso de três anos, por exemplo: "Obter uma mente não maniqueísta”, “Adquirir o autoconhecimento". Uma lista de bibliografia também é sugerida para o $1^{\circ}$ e $2^{\circ}$ anos, e artistas indicados pra o $3^{\circ}$ ano de curso. Entre a bibliografia sugerida, vale destacar a grande variedade: “3. CASCUDO, Câmara, “Ant. Folclore Brasileiro” [...] 14. NIETZSCHE, Friedrich, "Fisiologia da Arte" [...] 22. SANTOS, Milton [...]".

O prospecto apresenta apenas sugestões de leitura e não de aprendizado de técnicas, em uma clara intenção de desenvolver idéias. Este programa é o oposto dos cursos como o do ICCLA — vide prospecto na página 130 - mais voltados para o exercício da técnica. No caso de Rubens Espírito Santo, a junção artista/professor também ocorre de forma curiosa, uma vez que ele aproveita as discussões em aula como matéria de sua obra.

\subsection{Quarto Cenário: Cursos em escolas de pequeno porte}

Aqui situam-se as escolas que geralmente possuem espaços pequenos e/ou com pouca estrutura. Coloridos, com paredes cheias de telas ou muitas imagens, os espaços vazios parecem não ter sentido nestas escolas de pintura. Ao contrário do grupo anterior, estas escolas não transmitem uma sensação de austeridade ou sobriedade e refletem mais espontaneidade.

Elas revelam improvisos arquitetônicos: são espaços adaptados. Por exemplo, no Espaço Cultural Blue Life, a sala parece ter sido construída em um local destinado inicialmente a ser garagem; no Fruto da Arte, a sala está numa área lateral da loja de materiais artísticos; na Associação Parkinson, mesas com toalha de plástico florida (típica 
de um refeitório) transformavam a sala de convivência e jogos numa sala de arte. No entanto, as pessoas parecem estar muito confortáveis nestes espaços docilmente modificados. Aqui, só a funcionalidade do design dos móveis parece importar: a cadeira servir para sentar, a mesa para apoiar... Todo este improviso confere um ar de descontração, onde os freqüentadores expressam animação e contentamento. À vontade enquanto pintam, as pessoas conversam entre si, e demonstram uma relação afetuosa com seus professores/ orientadores.

Uma garrafa térmica em algum canto, umas bolachas de maizena... todos fazem pausa para o café, comemoram o aniversário de um colega com bolo surpresa, e, em meio a tanto ruído, produzem e pintam bastante.

Quem são essas pessoas que se satisfazem em meio aos improvisos? Neste grupo encontramos professoras e enfermeiras aposentadas, assim como donas de casa que só se sentiram livres para fazer um curso após o crescimento dos filhos, a chegada da viuvez ou ainda maior estabilidade econômica. Cabe indagar por que somente nesses espaços adaptados essas pessoas encontraram uma abertura para o desenvolvimento da prática artística.

Esse ambiente animado pode ter uma coerência com a visão que a dona da escola Fruto da Arte tem sobre seus alunos. Segundo ela, muitos dos alunos que se inscrevem no curso de pintura do Fruto da Arte sempre tiveram o sonho de pintar, mas só depois de muito tempo puderam realizar isso:

"O perfil, no geral, são de pessoas que desde criança sempre tiveram vontade, que os pais jamais permitiram isso, ou que nem tinham condições de estudar, quem dirá fazer pintura. Então são pessoas que falam: 'Olha foi um sonho meu eu estar aqui'. Eu tenho alunos de 7 a 70 anos, e os de 70 anos comentam: 'Esperei um filho casar, o outro casar, o marido morrer, ter aposentadoria [...] meu pai não deixava, achava bobagem, o marido tinha ciúmes, agora eu vim fazer'. São pessoas que sempre sonharam fazer aquilo [...]. Você não tem noção da felicidade que causa aquilo. A gente faz tudo 
tão maquinalmente, que a gente esquece o quanto nós somos importantes para aquelas pessoas" ${ }^{66}$

A alegria de se dedicar a uma atividade prazerosa, que foi muito postergada, é evidente nessas escolas: isto compõe o ar festivo que preenche estes locais. Os alunos demonstram sua satisfação em terem superado os obstáculos que os privaram de se aproximarem da pintura durante muitos anos. A maioria deles aqui é aposentada ou possui mais de 55 anos.

Na Associação Parkinson, a aula de pintura também tem essa função de terapia ocupacional. Neste caso, pintar não significava exatamente realização de um sonho, mas uma opção de se reunir com colegas e pessoas com um problema em comum.

O colorido e o ruído destes espaços lembram exposições e feiras de arte que ocorrem em praças (como a feira de arte da Praça da República) onde, além de serem vibrantes e visualmente cheias de elementos (em oposição ao estilo clean e silencioso das galerias), muitas obras são expostas também em cavaletes. Lembra até o estilo museográfico mais tradicional de museus como o Louvre, onde quadros são expostos sem muito espaçamento e o ruído causado por tantos visitantes é bem alto.

Aqui, os estudantes de pintura estão quase sempre preocupados em copiar algo: uma natureza, uma foto, uma pintura. Por isso, nestes locais, existem os “álbuns de referência". Esses álbuns apresentam o assunto para se pintar, o que nestas escolas parece ser muito importante, já que importa mais o que se pinta em detrimento do como se pinta. No Fruto da Arte, por exemplo, existem grandes álbuns com imagens de paisagens bucólicas, ou vasos e frutas coloridos, que o professor classifica pelo grau de dificuldade. Estas imagens são, na maioria das vezes, pinturas de artistas que não estão identificados, e não são muito conhecidos, ao que parece. Isso talvez esclareça o fato de muitos alunos destes cursos não se lembrarem dos nomes dos seus artistas prediletos, e muitas vezes, ao serem perguntados sobre o pintor de que gostam, citam o próprio professor como

\footnotetext{
${ }^{66}$ Entrevista com a professora e proprietária do Fruto da Arte.
} 
referencial. Embora eles vejam outras pinturas, muitas delas são anônimas. Na Associação Parkinson também havia uma caixa com recorte de imagens para temas de pintura ainda mais variadas: imagens de propagandas, revistas, cartões de Natal, tudo servia como referência ou assunto para os alunos pintarem. Os alunos escolhiam a imagem e copiavam para a tela, com o auxílio de uma folha de seda (ou papel vegetal trazido de casa).

Não se encontram nestes álbuns imagens de grandes mestres da pintura, por exemplo. Por vezes, encontramos artistas que figuram em revistas voltadas para um público de escolas de pintura. No Fruto da Arte pode-se também comprar algumas destas publicações periódicas. Um exemplo destas revistas é a revista Galeria em Tela (vide p. 130). No seu número 29, traz várias fotos de pinturas de artistas do ateliê Norma Amaral (Anali Thurler, Gisele Aquino G. Morais, Marlene Seabra, Wilma M. Gomes, Ivete Lopes). Logo na capa desta revista lê-se a manchete: "Monte um novo acervo. 56 sugestões para você pintar temas clássicos, modernos e contemporâneos". No corpo da revista encontramse muitas pinturas ao lado de um guia de cores, e algumas dicas de pintura. Neste trecho da revista, nota-se que a apresentação da obra é também uma indicação para a sua cópia: um interessante desprendimento em relação à autenticidade ou originalidade da produção! Uma forma de aceitar a arte como produção coletiva.

Esta mesma revista trazia também uma reportagem intitulada "Mostra Exemplar" sobre a exposição dos alunos de pintura do ateliê do MUBE e outra reportagem sobre o livro O olhar amoroso, escrito pelo crítico de arte Olívio Tavares de Araújo. Com matérias de qualidade ao lado de matérias simplistas - como o guia de cores para cópia -, essa revista sugere que públicos diversos têm acesso ao mesmo tipo de informação sobre arte.

Quanto aos materiais, a pintura em cavalete ou sobre tela montada e à tinta óleo predominam nestes espaços, remetendo a procedimentos tradicionais da pintura. Muitas podem ser as razões deste interesse pelo "assunto" e por uma pintura mais tradicional, de resultado mais agradável e decorativo como o repertório cultural e a concepção de arte. No entanto, acreditamos que exista também uma questão de "gênero", já que a maior parte destas escolas é freqüentada por mulheres. Segundo Eliana, a proprietária da escola Fruto da Arte, muitas alunas não possuem autonomia para atividades 
culturais que não estejam no planejamento familiar, e quando saem para fazer pintura, precisam mostrar um "resultado" convincente para o marido:

"Elas falavam assim: 'Nossa meu marido está me odiando [...] à noite eu estou desenhando ele fica com raiva...', como se aquilo indicasse, 'olha você está tomando seu tempo com uma coisa que não é pra sua família', 'você está à toa', 'isso é bobagem'. Então a arte ainda causa isso (ainda, não, isso é contínuo!).

[...] Eu tenho alunas moças que comentam: 'olha meu marido me deixou fazer aula, eu só posso vir uma vez por semana, à tarde'. Ai, por exemplo, eu quero levar para a Pinacoteca ou para o Masp, ela já não pode sair... E eu sinto que ela tem necessidade de levar um resultado. Eu não posso, por exemplo, chegar e dizer 'olha, vamos hoje trabalhar com linhas', vai ser uma aula perdida, ela tem que ter um resultado para levar pra casa". ${ }^{67}$

Por outro lado, sabe-se que as escolhas temáticas como paisagens rurais, bucólicas, flores, anjos estão de certa forma ligadas ao ambiente doméstico e ao imaginário dessas mulheres, e, por isso, bastante coerentes para esse grupo.

Os prospectos de divulgação destas escolas também refletem este interesse em uma pintura mais tradicional e em uma promessa de resultado, propondo, por exemplo, ensinar a criar uma assinatura artística, ou, ainda, como emoldurar a pintura. Alguns prospectos são de produção barata, e de tratamento visual poluído. São mais informativos e diretos: divulgam o programa do curso, o endereço e outras informações práticas. Apresentam diferentes tipos de letras e sinais, abusando ainda de suas variações como negrito e itálico. Alguns utilizam ainda uma letra "fantasia", como é o caso do prospecto do Fricote, onde o F se transforma em uma paleta de pintura (ver Narrativa Visual 3).

\footnotetext{
${ }^{67}$ Continuação da entrevista com a professora e proprietária do Fruto da Arte.
} 

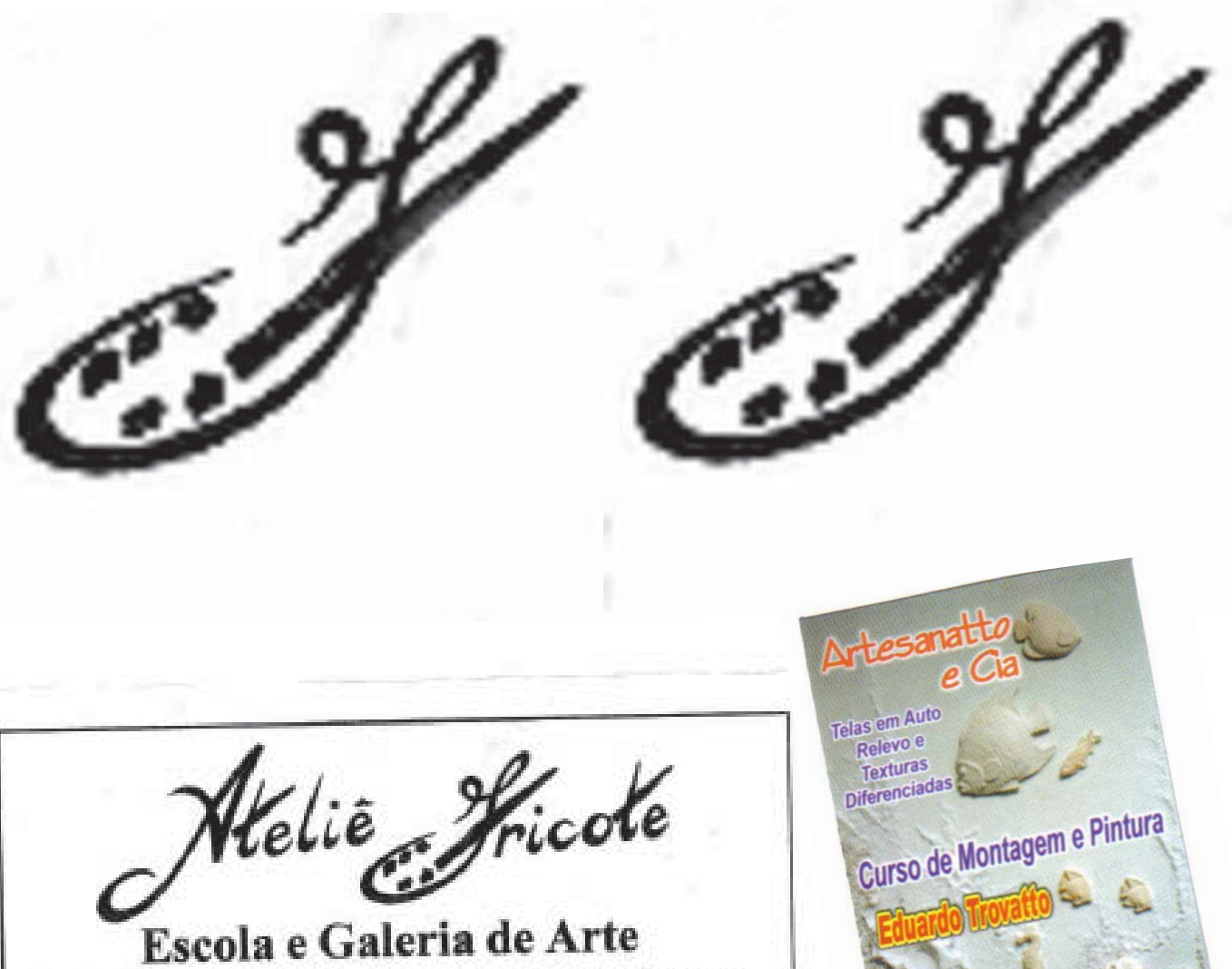

* Aulas de pintura do academico ao contemporalneo com professores especializados em téenicas e estilos dos mais variados.

- Quadros a óleo e/tintas importadas prontos ou sob encomenda.

$$
\text { Fones: } \begin{aligned}
& \left(0^{* * 11)} 3331-8797\right. \text { ( Com.) } \\
& \left(0^{* * 11}\right) 3258-7027 \text { (Res.) }
\end{aligned}
$$

Rua Marquezde hu, 266-A-Centro-Cep:01223-000

Slo Pauto/SP - ( Aberro Tamém nos Dommgos bas 8 is 14:00 Hs)
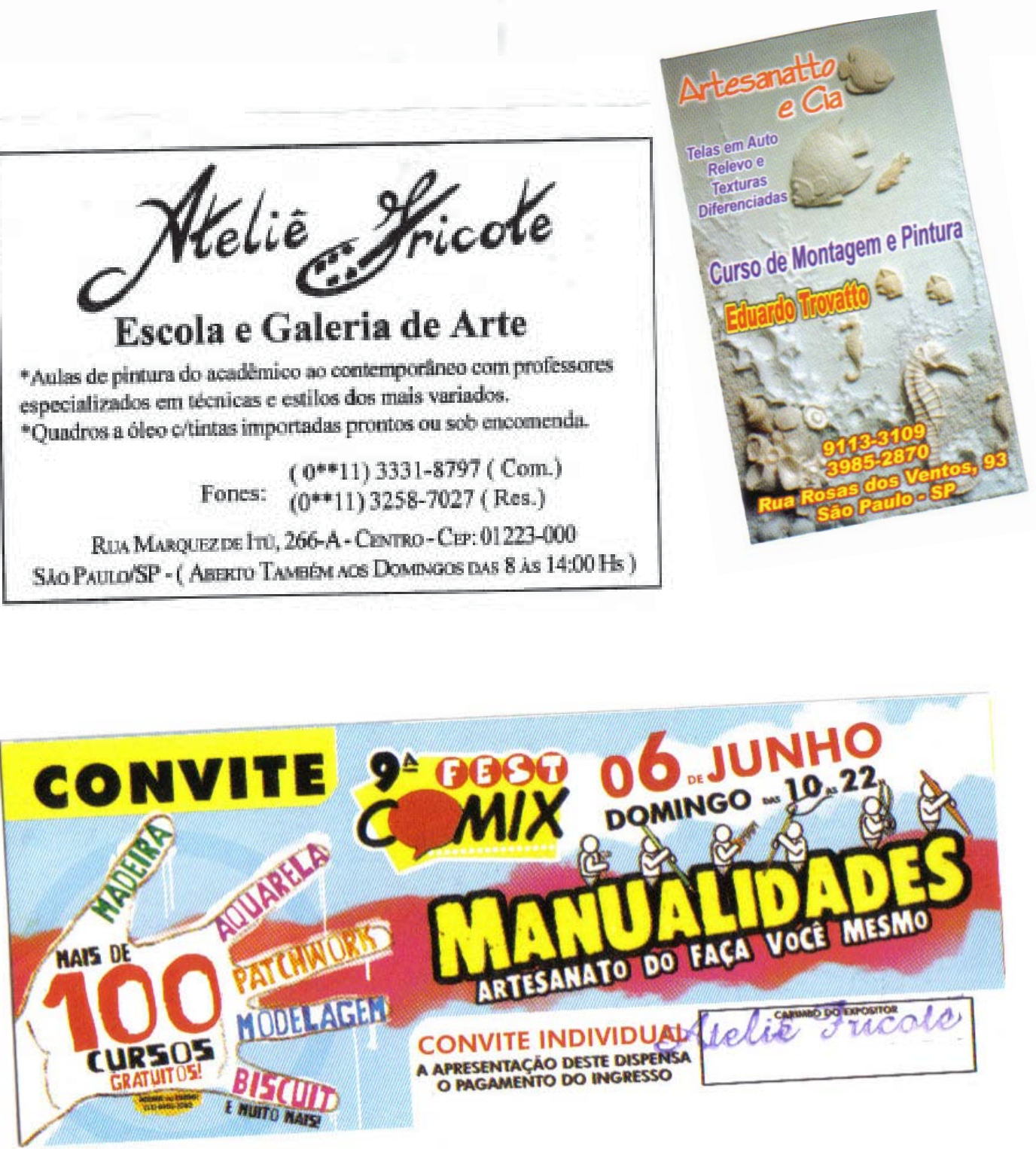
Associação Brasil Parkinson

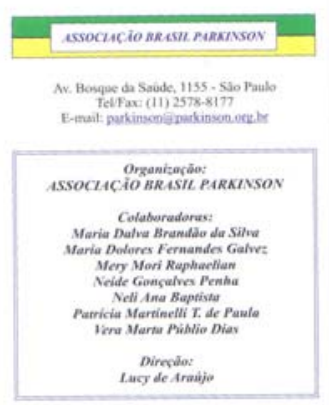

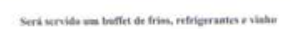

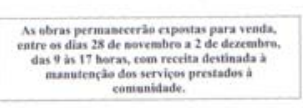
APOIO

Cetizie Vieira, Bizzo e Oliani

Adrogades Associades
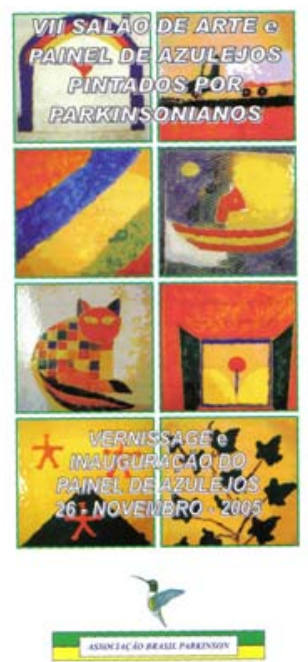
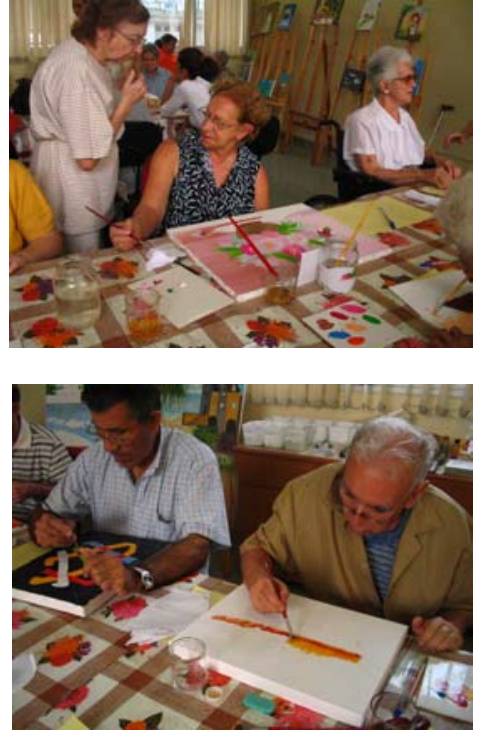
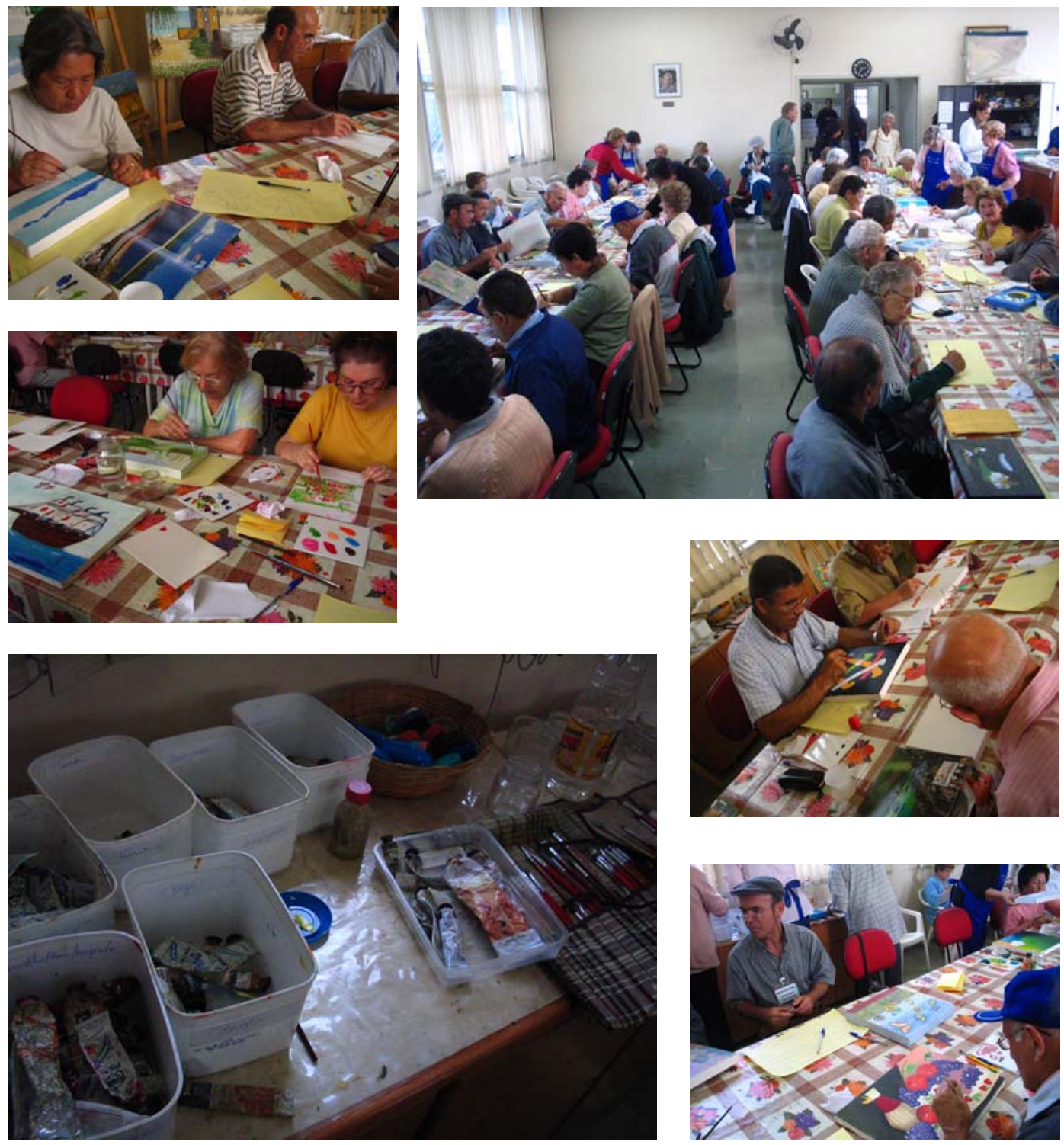
Escola Fruto da Arte
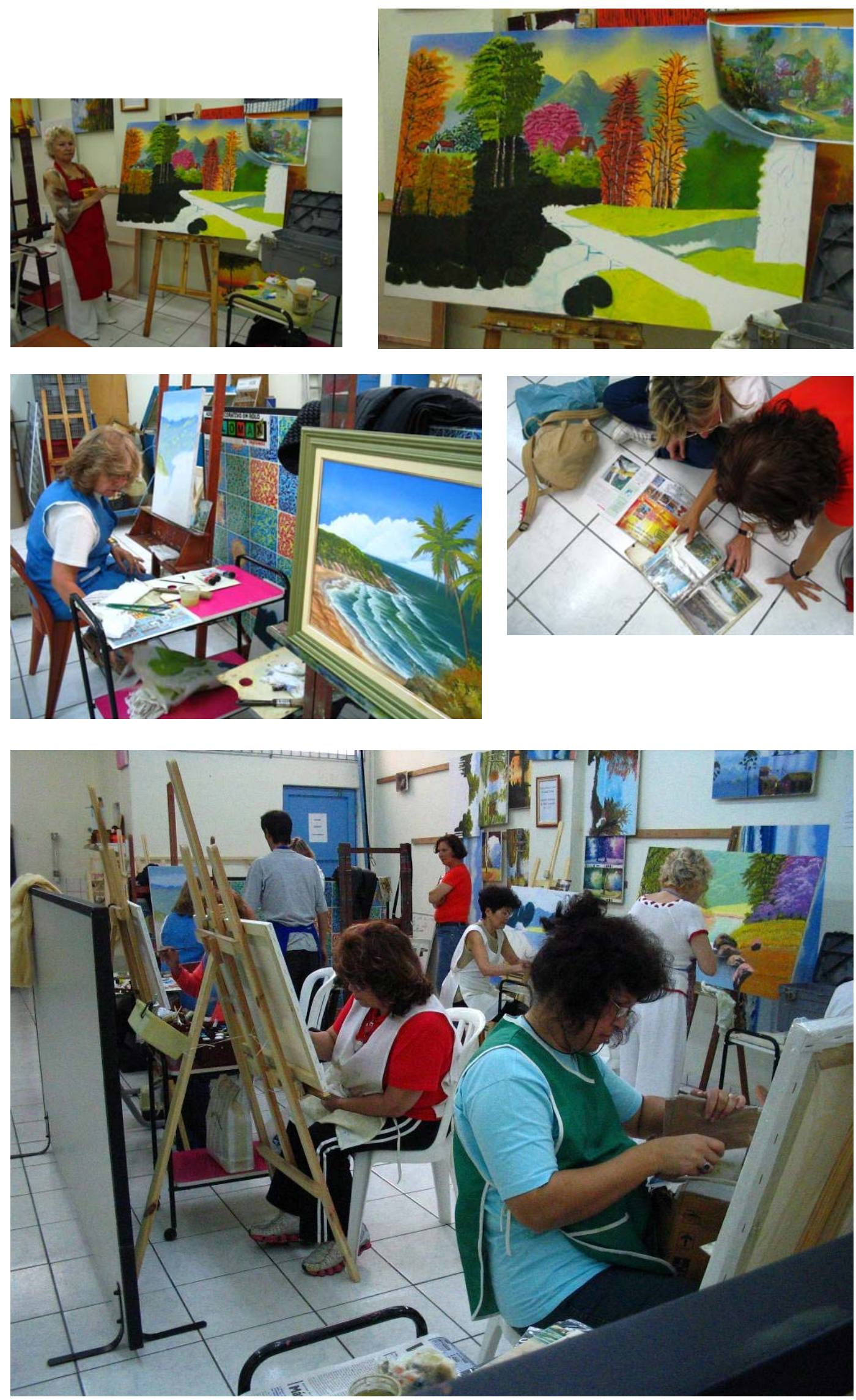
Cultural Blue Life
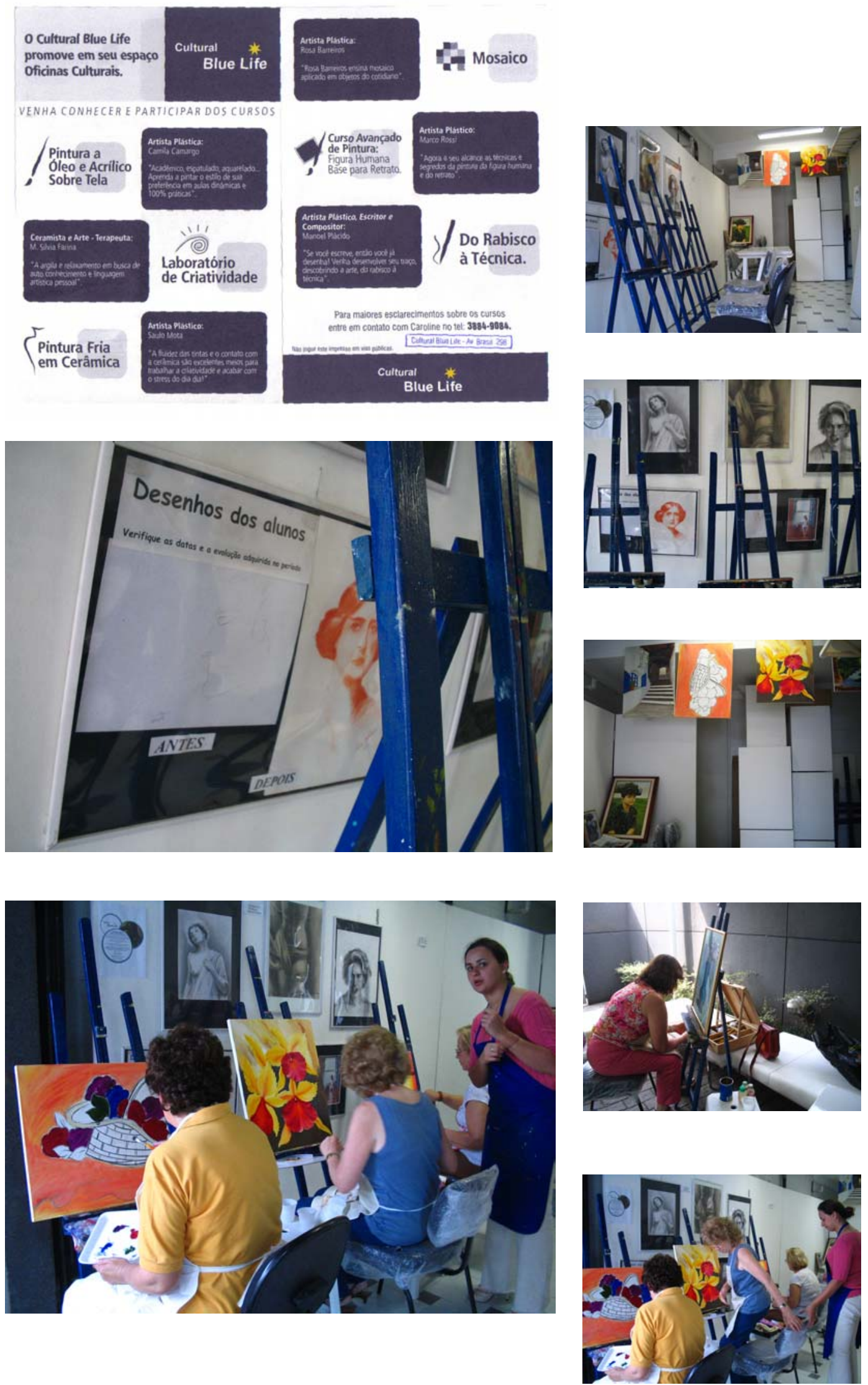


\subsection{Quinto Cenário: Cursos de Pintura ministrados na casa dos professores}

Alguns cursos de pintura são ministrados nas próprias casas dos professores, como os cursos de Eva Soares e de Marcos Rossi. Embora com espaços mais reduzidos, proporcionam uma grande proximidade entre professor e aluno. Talvez isso explique a presença de alunos bolsistas (alunos que freqüentavam o curso sem ter que pagar), só encontrados nessa modalidade de curso.

Assim como nos ateliês, esses espaços possuem as obras dos professores nas paredes, mas, pelo local ser também uma sala de estar (da casa), não há tantos vestígios do processo de criação. Interessante notar a grande capacidade de organização destes espaços multifuncionais, que normalmente utilizam cavaletes para abrigar as pinturas de seus alunos e se aproximam muito do primeiro grupo (escolas de pequeno porte).

Estes cursos recebem a interferência de uma rotina mais caseira. No caso de Eva, em aula ocorrida numa emenda de feriado, suas três filhas (entre 3 e 5 anos) circulavam com curiosidade pelo espaço. Já no ateliê de Rossi, uma dezena de gatos pulava por entre telas e alunos. São situações que parecem adversas, mas que acabam por configurar um cenário bastante curioso, e que parece não interferir em nada no prazer de pintar dos alunos. 
NARRATIVA VISUAL 4: Cursos em casa

Casa de Marcos Rossi
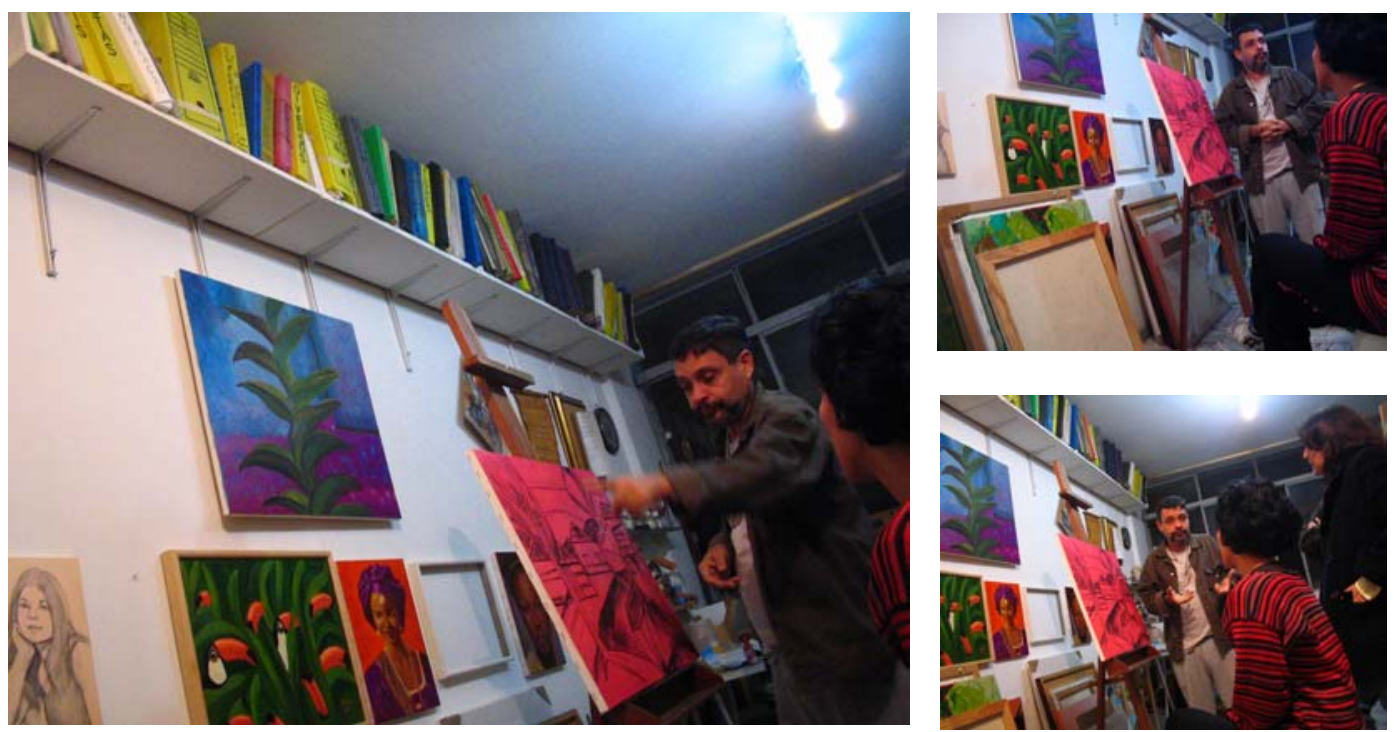

Casa de Eva Soares
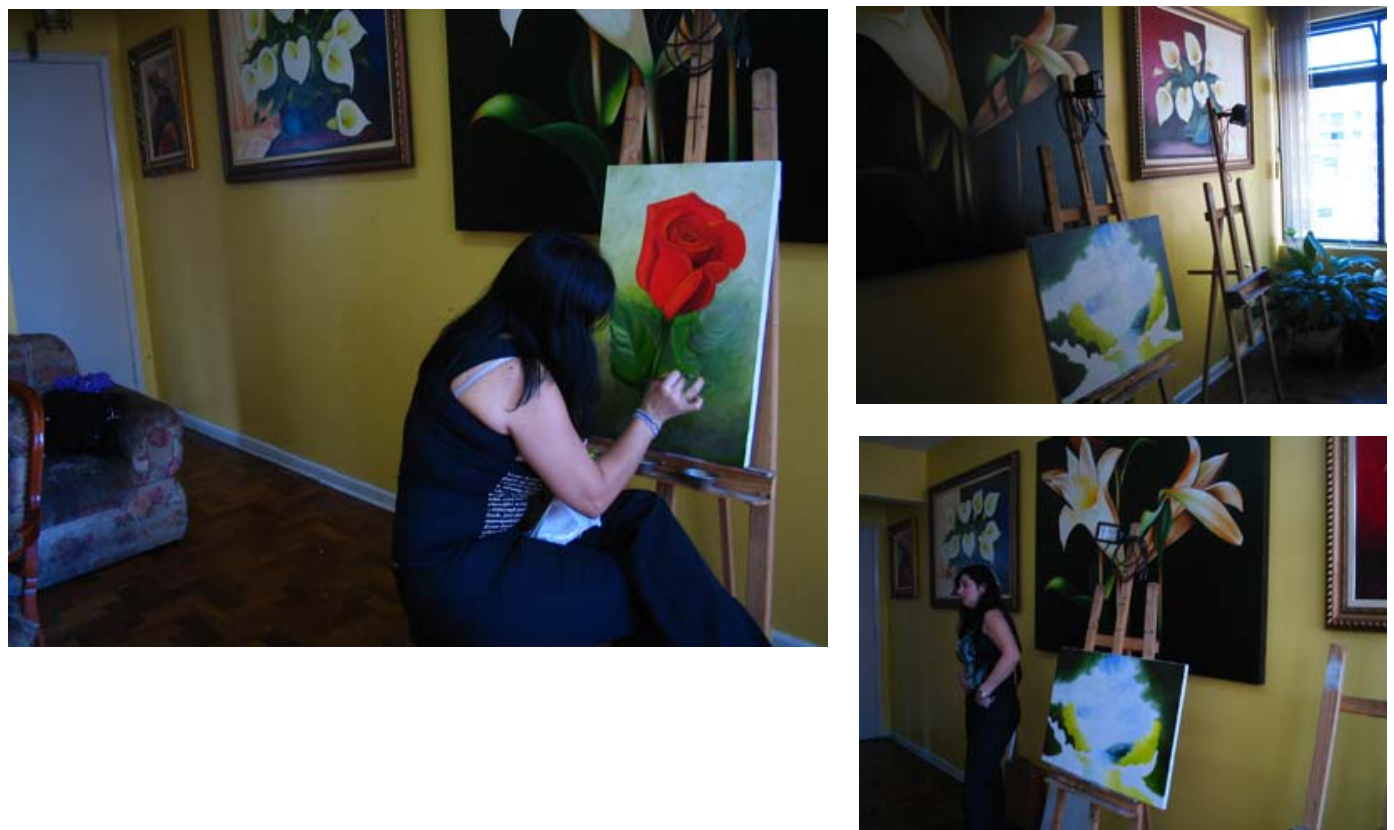


\section{6 Considerações sobre os diversos cenários - escolas de pintura}

Muitos alunos relatam que já passaram por diversos cursos livres: de modelagem, aquarela e também cursos de técnicas artesanais como o batique. Foram citados ainda outros cursos, como o do Centro Cultural São Paulo, de desenho com Dalton, Sumi-ê, Escola Panamericana de Arte, aquarela com Iole Di Natale, Liceu de Artes e Ofícios etc. Conscientemente ou não estas escolhas também são feitas a partir de uma dada concepção de arte.

Esta pesquisa não pretende fazer uma comparação entre o ensino universitário e o de cursos livres. Entretanto, em alguns casos é inevitável o questionamento de porquê alguns alunos recorrerem a tantos cursos no lugar de se inscreverem em uma faculdade, onde teriam as disciplinas de forma mais organizada e até, em alguns casos, gastando menos. Esta mobilidade nos convida a refletir que os alunos, nos cursos livres, têm maior autonomia de montar a sua proposta curricular de formação pois podem escolher a técnica, o tempo de permanência e até o tipo de orientação preferido. Nas entrevistas, várias alunas relataram que embora gostem muito de fazer arte, não acham que teriam disposição para fazer uma faculdade. Algumas acham que já possuem idade avançada para fazer o curso superior de arte, outras têm clareza de que não teriam paciência para cursar disciplinas de educação ou história da arte, já que se interessam mais pela prática e possuem um conceito de arte distinto do oferecido nas universidades.

Embora com públicos muito diferentes, foi a partir da perspectiva de Bourdieu que se pode indagar sobre uma certa interdependência entre os diferentes cursos de pintura, e os outros espaços de formação em arte. Os grupos de escolas de pintura mais caras, aqui definidas como escolas de grande porte (mais próximos de um campo de dominação), acabam por se distinguir das escolas de pequeno porte ${ }^{68 .}$

\footnotetext{
${ }^{68}$ BOURDIEU, P. La distinción: criterio y bases sociales del gusto , op. cit ., p. 231.
} 
Essas diferenças ajudam então a reforçar a distinção dentro do próprio campo, entre os velhos e os novos, os vulgares e os experimentais, os sentimentais e os intelectuais, fazendo uma paródia ao campo de produção de moda exemplificado por Bourdieu. Afinal, de quem se diferenciariam os dominantes do campo da cultura, se não existisse nenhuma outra espécie de produção variada e múltipla. Se no campo de bens culturais, existem muitas lutas internas, com idéias e comportamentos muito distintos, elas nada mais fazem do que alimentar um moto continuum do poder do campo.

E o interessante, ao analisar os cursos livres sob a perspectiva de campo de Bourdieu, é notar que práticas tão distintas têm uma função importante de "objeto de diferenciação e distinção", uns em relação aos outros. Se alguns deles não ocupam uma posição de luta pelo poder, e isso é fácil de perceber pela despretensão dos praticantes de algumas escolas pequenas e pelos espaços pelos quais buscam expor e freqüentarsempre à margem das instituições -, eles possuem, sim, uma posição de manutenção do campo de poder. Ou seja, eles alimentam a prática a ser negada, representam o oposto a ser negado.

Embora os espaços evidenciem uma concepção de arte, e suas decorações, tais como analisamos, sigam um ideal artístico $^{69}$ e expressem um conjunto de comportamentos (um habitus) bastante característico, eles não conseguem homogeneizar suas práticas: a relação é dialógica. Mesmo existindo uma predominância de práticas num espaço, os interesses diversos permanecem em todos os contextos. Portanto, com base nesse panorama geral não poderíamos afirmar que todos os alunos de uma mesma escola, por exemplo, têm a mesma concepção de arte. Para discutir as concepções de arte que cada aluno possui é necessário um close-up, aproximar-se das pessoas, o que foi feito por meio de entrevistas, e que será apresentado no próximo capítulo.

\footnotetext{
${ }^{69} \mathrm{~A}$ palavra é usada no sentido que Pareyson aponta: que existe em produções cotidianas a expressão de um "ideal estético", que é diferente de possuir uma "estética", como ouvimos no senso comum (PAREYSON, L. op. cit., p. 36).
} 


\subsection{Formação dos professores dos cursos livres de pintura}

A construção de uma idéia sobre a formação do artista pressupõe uma concepção de arte. Por exemplo, a idéia de um aprendizado que se realiza via mestrediscípulo ressalta uma concepção mítica da arte. Também a formação sistematizada do curso universitário se aproxima de uma visão de profissionalização que transcende as idéias de talento e genialidade.

Nestes cursos livres, a formação universitária dos professores predomina e parece ser valorizada. Algumas vezes, nos cursos livres em que o professor não possuía um diploma, notamos que a pergunta “O professor é formado?” causava incômodo. Esse mal-estar podia ser conseqüente de uma valoração social do diploma. Uma solução parcial foi modificar a pergunta para: "Qual é a formação do professor? Foi com outros artistas? Autodidata? Ou ele fez algum curso? Alguma faculdade?". O prolongamento da pergunta evitou que o entrevistado se sentisse checado.

Teresa Viana e Rubens Espírito Santo fazem parte de um grupo de treze professores que disseram ter formação com artistas e em cursos livres. Nestes casos a formação não-acadêmica foi afirmada com desenvoltura e contrabalançada pela experiência e êxito profissional dos professores.

No caso da titulação escolar, além de ela garantir um universo de conhecimento específico, também acaba por inculcar uma outra série de comportamentos culturais gerais (o modo de se vestir, a entonação da fala), que caracterizam o que Bourdieu chama de homem cultivado. A titulação, assim compreendida, garante uma série de outros comportamentos e disposições gerais, que transcendem a especialidade da titulação. Mas a aquisição da cultura não se dá somente através da escola, a escola muitas vezes representa um meio acelerado de adquirir a cultura que não se pode adquirir de outro modo.

Dentre os não-graduados havia uma professora que estava estudando Educação Artística na UNICSUL e outra que havia desistido do curso na Faculdade Santa Marcelina, 
por achá-lo muito teórico. Os outros professores se consideravam autodidatas, atribuíam sua formação a outros “mestres”, professores, ou ainda a cursos no exterior. A informação “curso no exterior" é sempre vaga, e deve conter uma gama diversificada de formação.

No entanto, mais da metade dos professores possuía graduação em arte. E, por não ser a graduação uma exigência legal para se lecionar em cursos livres (ao contrário do que ocorre na escola formal), essa estatística impressiona. Neste sentido, como apontamos anteriormente, os cursos livres não estão tão independentes, ou à margem, do ensino formal.

Apesar da formação relativamente comum, a didática e as formas de ensinar observadas são variadas. Analisar a didática dos cursos livres resultaria outra pesquisa, de tão variada: em alguns cursos, os professores propõem um exercício único para todos os alunos; em outros, cada aluno recebe uma orientação individualizada; e existem alguns cursos em que quase não existe orientação, mas apenas o fornecimento do material de trabalho e local apropriado. Assim como os alunos, os professores não compartilham da mesma visão de arte, nota-se isso pela forma como comentam os trabalhos dos alunos, nos livros que levam, nos artistas que referenciam, nos materiais que indicam. 
ESCRITOS DO MEIO III

Do diário 


\section{Dos diários}

\section{Trecho do diário da Tese - dia 15 de setembro de 2005:}

\section{entrevista com alunos do curso livre do Collegio das Artes:}

O maior impacto que tive ao visitar o curso livre do Collegio das Artes foi em relação à qualidade que encontrei nas pinturas dos alunos: não pareciam pinturas feitas por iniciantes. Embora alguns alunos tivessem apenas um ano de curso, faziam telas enormes, pinturas abstratas que discutiam relações mais formais da linguagem da pintura, como forma e cor.

Fiquei impressionada com a orientação do professor artista, o Paulo Whitaker, que era muito pessoal. Aparentemente desprovida de um planejamento, no sentido tradicional, a sua aula não tinha um objetivo predeterminado, percebiase que ele orientava os alunos à medida que o solicitavam. O professor olhava, fazia comentários, sugeria alguns artistas... e isso parecia funcionar muito bem.

As várias estruturas de planejamento que aprendi pareciam ser muito burocráticas perto da organização da aula do Paulo. Embora a proposta da pesquisa não seja a de avaliar a didática dos cursos livres, percebi que a didática de alguns desses espaços poderia também auxiliar no estudo da didática para o ensino formal. Por exemplo, a proposta do Collegio das Artes é bastante aberta, os cursos não possuem sequer uma duração exata: os alunos podem freqüentar dois ou quinze meses um mesmo curso. Não existe nenhuma proposta de conteúdos ou objetivos no curso.

Por outro lado, quanto à concepção de arte, o Collegio das Artes era o que mais se aproximava da minha formação. 
O que o tornava um pouco desinteressante para mim como pesquisadora. Por outro lado, cheguei a invejar pessoas que estavam lá, desenvolvendo suas pinturas, discutindo seus resultados com outras pessoas, sem compromisso de fazer outras disciplinas, de terem que entregar um monte de esculturas, desenhos e gravuras...

A minha linguagem era mais próxima desses alunos que referenciavam os mesmos espaços e também os mesmos artistas que eu conheci, pareciam compartilhar dos mesmos sonhos que já tive um dia. Assim, o meu deslocamento deveria ser menor, e a minha desenvoltura maior num espaço assim. No princípio, essa escola não ofereceria muito estranhamento ou dificuldade de análise. No entanto, a sua proximidade de um campo legítimo me propõe uma reflexão ainda maior: a de pensar a concepção de arte que eu, a tanto custo, tento e pretendo desconstruir.

Estes seriam os amadores, mais próximos aos profissionais, segundo Stebbins (1992), mas ainda amadores, principalmente pelo imenso prazer que revelam ter em pintar. No Collegio das Artes senti ressentimento ao ver nos outros o prazer que eu havia perdido na produção artística. Por alguns momentos, eu não queria ser a pesquisadora, queria ser um deles, os pesquisados, os amadores da arte.

Agora eu não podia mais mudar de posição. Eu estava lá para pensar o "prazer" dos outros. Claro, me refiro a esse "prazer" angustiante da criação, que é privilégio dos que possuem creencia artística*, a crença que perdi.

Uma atração e uma repulsa. Uma contradição.

Isso me faz pensar como que posso ter sido vítima de uma imagem profissional de artista, incentivada pela historiografia da arte, com "fórmulas biográficas" de tantos artistas angustiados, sérios, tristes, melancólicos e deprimidos. O prazer relacionado à prática artística se transformou em sentimento de culpa. As narrativas biográficas presentes na história da arte** 
acabam muitas vezes por formatar a idéia profissional e, mesmo indiretamente, influenciar na idéia de identidade profissional. E, neste sentido, olhar a prática dos amadores, serve-nos para desconstruir a forma tida como única de se relacionar com o fazer artístico.

A dona dessa escola freqüentou a mesma universidade que eu, foi minha colega de curso, o que facilitou o meu acesso aos alunos. Para leitores da pesquisa, essa escola pode ajudar a situar o lugar (ou o lugar de negação) da minha análise. A concepção de arte que dominou todos os meus espaços de formação em arte era muito próxima à do Collegio das Artes (só que com menos liberdade e prazer).

Se o Collegio das Artes pretende ter uma relação com a arte mais formal, ao observar nesta escola as práticas dos alunos, e após entrevistálos, observo um desvio dessa intenção, que é mesclada com uma relação bastante leve e próxima do autoconhecimento. Aqui a arte tem uma função de expressão, de conhecer a si mesmo, de entrar em contato com as próprias emoções.

Essa mescla entre arte como investigação e arte como expressão existia também na universidade que cursei, mas era dissimulada, já que todos reconheciam que lá a arte deveria ser uma coisa séria, não poderia ser hobby ou prazer. Também me lembro de ter vários colegas que se assemelhavam aos alunos do Collegio das Artes: mulheres que não precisavam, não queriam trabalhar, ou viram-se livres do trabalho doméstico escolheram um curso que pudesse servir para seu desenvolvimento pessoal: muitas não terminavam o curso, e, penso hoje, que eram praticamente expulsas, excluídas por não se adequarem ao formato profissionalizante (androcêntrico ) .

\footnotetext{
* Uma paródia ao nome do livro de Bourdieu, Creencia artística y bienes simbólicos.

** KRIS, Ernst; KURZ, Otto. La leyenda del artista. Madrid: Cátedra, 1995, p. 112.
} 
CAPÍTULO 3

LIBIDOS ARTÍSTICAS 


\section{Libidos $^{70}$ artísticas}

As idéias de arte que orientam as práticas dos alunos das escolas livres de pintura permitem interpretar as principais concepções de arte dos amadores e investigar suas múltiplas características e motivações.

Desde o princípio, guiam esta observação e esta análise as concepções de arte "como manifestação dos sentimentos", "como forma de conhecimento" e "como técnica e fazer". Verifica-se na história da arte ocidental a coexistência destas diferentes concepções, ainda que com a predominância de uma concepção sobre as outras; a observação e análise etnográfica dos cursos livres de pintura não difere disto: grande parte dos amadores de arte manifestaram simultaneamente múltiplas concepções, por isso, para classificá-las, usa-se o critério de preponderância, isto é, analisa-se qual concepção de arte prevalece. Entretanto, diferentemente da historiografia da arte, trabalha-se com a sobreposição de todas essas concepções em um só tempo, o presente. Elimina-se qualquer possibilidade de falar das práticas dos amadores da arte de forma homogênea, reconhecendo que mesmo dentro de cada concepção artística são enormes as diferenças em relação às aproximações com a arte. E as regularidades ${ }^{71}$ ao mesmo tempo em que indicam intenções comuns perante o fazer artístico não excluem trajetórias pessoais singulares nem as nivelam.

Com a preocupação apenas em reconhecer as motivações de cada grupo e demonstrar no que se pautam as suas concepções de arte, não se estabelece diferenciações

\footnotetext{
${ }^{70} \mathrm{O}$ termo libido é empregado por Bourdieu para definir o interesse pela arte. Como já comentamos na nota da página 33, o sociólogo se refere a uma libido artística, porque, como comenta De Certeau, trabalha a partir de estruturas estáveis. Mas se consideramos a teoria de M. de Certeau, podemos acreditar em várias libidos artísticas, por isso a utilização do termo libidos no plural.

${ }^{71} \mathrm{O}$ termo "regularidade" foi emprestado de MAGNANI. J. G. C. Mystica urbe: um estudo antropológico sobre o circuito neo-exotérico na metrópole. São Paulo: Nobel, 1999; MAGNANI, J. G. C.; TORRES, L. de L. (orgs.), op. cit.
} 
quanto ao possível grau de desenvolvimento dentro de cada concepção de arte, o que resultaria num outro possível trabalho.

Embora as escolas evidenciem uma concepção de arte (que foi analisado no capítulo anterior), elas possuem alunos que nem sempre a reproduzem. Assim, far-se-á aqui uma análise centrada nos indivíduos e não nas escolas, como mostra o quadro "Relação dos alunos por concepção de arte predominante", no qual se nota que uma mesma escola reúne alunos com distintas concepções de arte.

TABELA 4: Relação dos alunos por tipo de concepção predominante de arte

\begin{tabular}{|c|c|c|c|c|c|c|c|c|c|c|c|c|}
\hline & \multicolumn{3}{|c|}{$\begin{array}{l}\text { Ateliês de } \\
\text { artistas }\end{array}$} & \multicolumn{2}{|c|}{\begin{tabular}{|l|} 
Casas \\
dos \\
professor \\
es
\end{tabular}} & \multicolumn{3}{|c|}{$\begin{array}{l}\text { Escolas de } \\
\text { grande porte }\end{array}$} & \multicolumn{3}{|c|}{$\begin{array}{l}\text { Escolas de } \\
\text { pequeno } \\
\text { porte }\end{array}$} & \multirow[t]{2}{*}{$\begin{array}{c}\text { Total de } \\
\text { alunos } \\
\text { por } \\
\text { concepção } \\
\text { de arte }\end{array}$} \\
\hline & 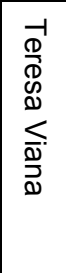 & 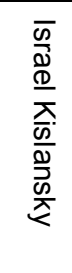 & 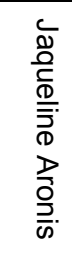 & $\begin{array}{l}\text { m } \\
\infty \\
\infty \\
D \\
\stackrel{D}{\mathbb{D}}\end{array}$ & 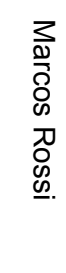 & $\begin{array}{l}-1 \\
\text { Oे } \\
\frac{3}{\bar{D}} \\
\frac{0}{O} \\
\frac{\vec{D}}{\hat{D}}\end{array}$ & 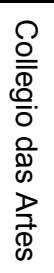 & $\frac{\underset{\mathbb{D}}{\mathbb{\mathbb { D }}}}{\frac{\mathbb{D}}{2}}$ & 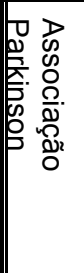 & $\begin{array}{l}\frac{1}{2} \\
\frac{1}{c} \\
0 \\
0 \\
0 \\
D \\
\frac{2}{2} \\
\frac{1}{D}\end{array}$ & $\begin{array}{l}\frac{\underline{\sigma}}{\bar{\Phi}} \\
\frac{\Gamma}{\bar{\Phi}}\end{array}$ & \\
\hline $\begin{array}{l}\text { Arte como } \\
\text { técnica }\end{array}$ & $\overline{0}$ & $\overline{0}$ & 0 & $\overline{11}$ & 1 & 0 & 0 & $\overline{0}$ & 0 & 1 & $\overline{1}$ & 4 \\
\hline $\begin{array}{l}\text { Arte como } \\
\text { Expressão }\end{array}$ & 2 & $\overline{11}$ & 2 & 0 & 1 & 2 & 1 & $\overline{11}$ & $\overline{11}$ & 1 & 2 & 14 \\
\hline $\begin{array}{l}\text { Arte como } \\
\text { conhecimento }\end{array}$ & 1 & 2 & $\overline{0}$ & 0 & 2 & $\overline{0}$ & 0 & 0 & $\overline{0}$ & 0 & 0 & 5 \\
\hline
\end{tabular}

Ao observar que as práticas artísticas estão orientadas por diferentes concepções de arte, a seguir são apresentados alguns critérios de julgamento e validação que acompanham essas concepções e práticas artísticas diferenciadas. Esses critérios indicados nos quadros deste capítulo são também um caminho indicado por Chalmers ${ }^{72}$, que ressalta a importância de se discutir o que se compreende por "boa arte" em diferentes

\footnotetext{
${ }^{72}$ CHALMERS, F. G. Arte, educación e diversidad cultural. Barcelona: Paidos, 2003, p. 38.
} 
contextos culturais, um modo de operação possível para compreender o multiculturalismo. Destaca-se que neste trabalho seria difícil discorrer sobre todas as práticas observadas, a partir de um critério único e essencial de $\operatorname{arte}^{73}$.

\subsection{Táticas contra uma relação distanciada com a arte: Arte como expressão (ou manifestação dos sentimentos) e arte como técnica (ou como fazer).}

Discute-se aqui as concepções de fazer artístico que se opõem ao distanciamento estético, proclamado desde a modernidade como a única forma adequada de se relacionar com arte. Denominam-se táticas ${ }^{74}$ as práticas que atuam dentro de um contexto adverso, em um macrocenário cultural que institucionalmente não evoca tais práticas. São aqui consideradas táticas as ações desajustadas ao proclamado por algumas ações públicas, como por exemplo no ensino institucionalizado. A partir da concepção de Michel de Certeau a tática pode ser também uma produção dos consumidores, que, não passivos, criam táticas expressas em práticas que subvertem uma determinação única de consumo. Portanto, neste caso, seriam táticas artísticas aquelas que predominantemente carregam uma concepção de arte como técnica (fazer) ou como manifestação dos sentimentos e autoconhecimento (arte como expressão). Ainda que consideradas anacrônicas, pragmáticas ou naturalistas, essas concepções subsistem, e são quase dominantes ${ }^{75}$ nos cursos livres de pintura, cabendo interpretar qual a lógica que estrutura estas práticas. Essas concepções, expressas pelas práticas, são híbridas e não ocorrem dentro de um previsível "modelo" de fazer arte hoje.

\footnotetext{
${ }^{73}$ SHUSTERMAN, R., op. cit., p. 32.

${ }^{74}$ Tática é um conceito de CERTEAU, M. de op. cit.

${ }^{75}$ Dominam no subsolo, e se revelam numa observação etnográfica local.
} 


\subsubsection{Arte como expressão dos sentimentos}

Muitos praticantes de pintura dos cursos livres afirmam pintar para manifestar e conhecer as próprias emoções, para, através da pintura (ou da arte), dar vazão, "liberar" e resgatar os sentimentos ocultos ${ }^{76}$. Inicialmente poder-se-ia relacionar essa intenção com a função da arte como expressão. A arte como expressão foi um dos objetivos mais presentes nos planos de ensino de aulas de arte nos anos 1970 e 1980, décadas em que muitos dos entrevistados (dos cursos visitados) freqüentaram a escola. Após os anos 1980, a “expressão” foi praticamente banida dos planejamentos de ensino, por relacionar a arte com um plano "mais espiritual" e subjetivo, difícil, portanto, de ser ensinada e avaliada de maneira sistematizada. No Brasil, essa concepção de arte como expressão muito influenciada pelas teorias da Escola Nova acarretou o esvaziamento dos conteúdos históricos e da linguagem da arte. As aulas de arte, sob essa influência, consideravam insignificante o contato com a história da arte e eram marcadas por atividades de livre experimentação.

Genericamente, a "expressão" entendida como manifestação dos sentimentos, continua sendo uma ação associada à arte. Nos filmes, nas representações da profissão, o artista aparece geralmente como sensível, emocional e pouco racional. Freedman ${ }^{78}$ afirma que nos meios de comunicação os artistas são representados como gênios de caráter "desviado" ou como excêntricos que levam suas emoções ao extremo. Todas essas informações culturais transmitem idéias sobre arte. Mesmo que não legitimadas, elas fazem hoje parte do universo comunicacional na suposição de que este ensina as pessoas a pensarem o que é arte. Por exemplo ${ }^{79}$, os estudantes ao freqüentarem a escola já possuem

\footnotetext{
${ }^{76}$ Obviamente existe uma gradação desta intenção, que se mescla com outras.

${ }^{77}$ FREEDMAN, K. "Curriculum Inside and Outside School: Representations of Fine Art in Popular Culture”. International Journal of Art \& Design Education, n. 16, v. 2, p. 137-145, 1997.

${ }^{78}$ Ibidem.

${ }^{79}$ Ibidem.
} 
uma idéia de arte e artista, criada dentro ou fora da escola. Essas representações de arte e de artistas influem na formação de uma concepção de arte, e isso é evidente nas entrevistas dos alunos de cursos livres de pintura ${ }^{80}$. Por mais que sejam "pastiche" de representações de artistas e da $\operatorname{arte}^{81}$, as imagens desses filmes revelam a corporificação de ideais da cultura ocidental, em que o artista torna-se ícone da idéia da liberdade, de autoconhecimento, e ligado a comportamentos sexuais não-padronizados (como homossexualidade, vida entre prostitutas, ou substituição do sexo pelo trabalho) e portadores de idéias autônomas (como se vivessem à parte da sociedade). Aliás, Ernst Kris e Otto Kurz ${ }^{82}$ comprovam que historiadores da arte também consentem e incorporam as míticas biografias dos artistas. Por meio de análises, os autores identificam na historiografia da arte vários temas biográficos comuns, tais como: criatividade divina, anonimato, manifestação do talento desde a infância (sugerindo que o artista seria superdotado e autodidata). Ao procurar cursos de arte, muitos estudantes pretendem entrar em contato com esse universo mitológico: estão em busca desse ícone e reproduzem essas trajetórias conhecidas. O relato e a crença de que uma aptidão artística surge desde a infância, por exemplo, é muito comum entre os amadores da arte entrevistados:

"[...] Eu comecei a pintar sozinha, surgiu assim um dom, ai as pessoas que iam em casa falavam assim: 'Faz um curso', [Aluna do Espaço Cultural Blue Life].

"[...] Na verdade sempre achei que eu tinha um pouco alma de artista, mas um pouco de preconceito, minha família dizia que eu iria passar fome [...] então eu acabei fazendo Direito, mas sempre me dediquei um pouco à arte" [Aluna do Marcos Rossi].

Ainda nesse sentido - o de entender a expressão como descoberta do próprio

\footnotetext{
${ }^{80}$ Acredito que está presente, de forma menos explícita, nos espaços mais formais, como universidades de arte.

${ }^{81}$ Ibidem.

${ }^{82}$ KRIS, E.; KURZ, O. op. cit.
} 
dom latente-, a pintura cumpre uma função de espelhar as emoções, refletir a sensibilidade e os estados de ânimo de seu autor. Assim, notamos nas falas expressões como: "lado extrovertido", "momento meu", "válvula de escape" e "extravasar", termos que identificam na arte esse lugar de refletir e realizar o que não se pode cotidianamente.

"Eu vou fazer uma faculdade que me ajude a mexer com esse lado extrovertido, que eu não tenho, que me ajude, quero me [sic] trabalhar nesse meu defeito [...] É um momento meu, são duas horas que eu fico aqui comigo, eu não penso em nada, então eu desenvolvo meu trabalho, faço minhas coisas e isso me ajuda no meu dia-dia. [...] Enquanto eu fazia faculdade (Educação Artística na Marcelo Tupinambá) eu procurei aqui, eu queria um curso de pintura, eu gostava, pra mexer também com esse meu lado, funcionar como uma terapia, mexer com uma coisa que me ajuda muito, porque aqui consigo colocar as coisas no papel, funciona mesmo como uma válvula de escape, vinte e um anos trabalhando numa empresa, ai você chega em casa e não faz nada... Então acho assim, a gente tem que estar sempre procurando algo para nós mesmos. Isso é importantíssimo, eu estava sentindo falta. Ai quando meu filho estava com 3 anos eu resolvi retomar aqui para extravasar um pouquinho, porque é muito complicado você trabalhar numa empresa um tempão" [Aluna do DELTA].

Esses praticantes crêem poder, através da pintura, lapidar a sensibilidade e conhecer melhor suas próprias emoções.

"[...] por exemplo, segunda-feira eu fiz uma tela pequena, comecei a fazer uns riscos, depois eu vi que era uma pessoa, ai fui pintando e no fim descobri que a pessoa que estava lá tinha uma perna maior que a outra: é interessante, porque depois da minha cirurgia, eu fiquei com uma perna maior que a outra, e a perna que aparecia era aquela. Porque isso está tão marcado a ponto de eu colocar isso inconscientemente numa tela?" [Aluna de Teresa Viana]. 
"Eu acho que a Arte é muito pessoal, [....] tudo que mexe com arte mexe com a emoção também" [Nair, da Blue Life]. "Puro descanso, puro deleite mesmo... [...] A arte traz para mim, neste momento, muito relaxamento, entretenimento. E mais: eu tenho minhas atividades normais do dia-a-dia, a rotina da casa, rotina das contas a pagar, rotina dos médicos, de hospital, essa coisa assim, então como se você tivesse a necessidade de criar alguma coisa, de passar um sentimento" [Fátima, Aluna na Blue Life].

"[...] Sempre bateu muito comigo isso, essa que é uma expressão no grafite, no papel, mas que é uma coisa que corresponde muito com o que você está internamente na época. E como eu andava muito travada ultimamente, eu resolvi vir para cá" [Aluna Delta].

"[...] Você vê seus desenhos antigos, feios, bonitos (não interessa), mas você vê como você estava, não só na técnica, mas como numa foto você vê como você estava, para mim, tem uma coisa assim, de recordação de mim mesmo. [...] Porque eu senti necessidade de fazer, porque eu acho que o desenho especificamente, ele vai te levando para outros lugares e outros conhecimentos além do próprio desenho, e lá ele desperta as dificuldades que você está sentindo na vida" [Aluna do ateliê escola Aronis].

A. C. Danto diferencia expressão e manifestação, afirmando que a primeira se explica por razões, enquanto a segunda por causas. A teoria de Danto evoca a expressão num contexto intencional, de uma relação distanciada com a arte. Para ele, os freqüentadores dos cursos de pintura não se expressam, mas sim se "manifestam", pois nessas práticas a pintura aparece como uma reação - quase natural, ainda que absolutamente cultural - de emoções que transbordam na pintura. Ele recorda que a palavra "expressão" tampouco é atemporal ou carrega um sentido único. Danto chama a atenção para uma palavra, sobre a qual, embora correntemente associada com a arte, tem-se refletido muito pouco. Refletindo sob a sua perspectiva, fazer arte como expressão pode significar fazer arte com razão, pensando a própria arte numa relação de 
distanciamento estético ${ }^{83}$.

Entretanto, esse grupo carrega o conceito mais romântico da palavra expressão, fortemente calcado em uma visão rousseauniana ${ }^{84}$, de expressão espontânea e natural dos sentimentos (que evoca o retorno do homem ao seu estado natural). Uma das alunas de pintura, por exemplo, ao ser perguntada sobre aonde gostava de ir para ver arte respondeu que "vê arte na própria natureza".

Para alguns alunos deste grupo, a arte não pressupõe nenhum distanciamento, é uma forma de despertar emoções como uma continuidade da vida. Alguns alunos, inclusive, ao pintar formas abstratas que aparentam uma pesquisa pictórica formal, têm em vista a auto-expressão, estabelecendo assim uma relação engajada e pouco “distante" com a pintura. Podendo ser associada à uma disposição kitsch, segundo a concepção de Giesz $^{85}$ - e isso não é nada pejorativo, já que ele caracteriza o kitsch mais como uma atitude do que como uma característica "estilística" que identifica certos objetos ${ }^{86}$. Para Giesz a disposição kitsch busca um desfrute sentimental que se distingue do distanciamento estético $^{87}$. Uma das evidências desse desfrute ${ }^{88}$ é o forte apelo sinestésico que essas pessoas buscam através da experiência com a arte..$^{89}$

En la vivencia kitsch, igual como sucede en el placer, la distanciación especifica de lo estético queda en gran parte suprimida a favor de un sentimiento de estado de ánimo. A ello se refiere la irônica observación de Hanslick de que el profano siente mucho más al escuchar música que el

\footnotetext{
${ }^{83}$ DANTO, A. C. Após o fim da arte. São Paulo: Edusp, 2003, p.65.

${ }^{84}$ NUNES, B. Introdução à filosofia da arte. São Paulo: DESA/Edusp, 1966, p. 64 (Coleção Buriti).

${ }^{85}$ GIESZ, L . Fenomenologia del Kitsch: Una aportación a la estética antropológica. Barcelona: Tusquets, 1973.

${ }^{86}$ Para Giesz a "disposição kitsch" está presente inclusive em toda "arte", na qual, por exemplo, a indução a estados de ânimo "falsos" são constantes. Uma grande marca da diferença entre o conceito de kitsch de Giez e o de Moles é que o primeiro não define o kitsch como características de estilo, mas sim como determinadas ações perante os objetos.

${ }^{87}$ Ibidem, op. cit., p. 52.

${ }^{88} \mathrm{Ibidem}$, p. 8 (Giesz parte da estética antropológica para afirmar que o kitsch não pode ser reduzido a uma categoria para designar (com juízo de valor) objetos, os objetos kitsch são apenas a objetivação de um desfrute. $\mathrm{O}$ autor na sua análise se concentra no desfrute kitsch, que pode estar presente em diferentes instâncias da vida e não só diante de determinados objetos).

${ }^{89}$ Ibidem, p. 96.
} 
entendido, porque el profano, entregado al placer, toma la obra de arte como ocasión propicia para vivir su propria afición, y no la obra de arte como portadora de valores. ${ }^{90}$

Percebe-se aí a arte como uma forma de experimentar as emoções ${ }^{91}$, como uma espécie de ilusión temporária, uma função utilitária afeita a provocar determinada emoção ou para entreter: é apenas um meio, e não o fim. Collingwood ${ }^{92}$ relaciona essa disposição, para manifestar emoções através da arte, da "arte como diversão": oposta à vida cotidiana, sem distanciamento, porém. Contemporaneamente, aloja-se aí a contradição, já que para muitos críticos contemporâneos só é legitima a disposição desinteressada para a arte, totalmente não funcional. No entanto, a intenção de fazer e ver arte - mais com os sentidos e menos com o intelecto - aparece em muitas práticas dos cursos: mesmo contestada pelos críticos e historiadores. A dimensão do entretenimento na arte é presente não só nos espaços informais, como nos cursos livres de pintura de escolas de pequeno porte; ela está presente também nas grandes instituições, já que os cursos de museus ou instituições culturais alimentam também esse "desfrute" que negam. Existe uma lacuna entre o discurso da arte e as práticas institucionais (até mesmo as que estão muito próximas de um campo mais legitimado).

A idéia de fabricação de Michel de Certeau aqui se objetiva: o uso da arte é oposto ao consumo proposto ou idealizado por muitas instâncias legitimadoras: dissonante e evidente, esse desfrute, ao revés, estava também nos cursos livres do Museu de Arte Moderna e do Instituto Tomie Ohtake (instituições que preponderantemente investem em uma arte reflexiva, bem exemplificado pelo movimento de arte conceitual).

Separar a arte que é diversão da que não é diversão, segundo o próprio Collingwood, pode ser também apenas uma marca de esnobismo. Ainda que saibamos que a arte e os artefatos nem sempre proporcionam momentos agradáveis, e que, pelo contrário, muitos ressaltem neles a fealdade e o desagrado, por que negar que pode haver

\footnotetext{
${ }^{90}$ Ibidem, p. 90.

${ }^{91}$ Por ser desligada da vida, essa "ilusión" é bastante diferente da magia.

${ }^{92}$ COLLINGWOOD, R. G. Los principios del arte. México: Fondo de Cultura Económica, 1960.
} 
a disposição para entreter-se diante de qualquer objeto? Alguns alunos procuram cursos de pintura movidos por essa disposição: de mover emoções, de buscar um local diferenciado da vida cotidiana, que relaxe, que dê uma "angústia gostosa".

A dimensão hedonista, do fazer e do ver arte, parece crescer, dentro e fora das instituições legitimadoras da arte. A freqüência a museus de arte é ocultamente alimentada pela indústria do lazer e do turismo, que cada vez mais colaboram para "o exercício superior da fantasia" anunciado ironicamente por Ronaldo Brito ao referir-se ao pósmoderno ${ }^{93}$. Ainda assim, as relações entre museus e públicos de arte não estão acordadas. Sob a perspectiva de análise das disposições estéticas dos amadores da arte, os esforços de alguns museus para tornar seus espaços mais democráticos, e, nesse sentido, oferecer uma experiência mais prazerosa, partem de um ponto de vista determinante, ao aplicarem uma roupagem de aproximação por meio de uma concepção de arte implicitamente determinada, inadequada para tal desfrute, o que pode causar o tal fetiche invertido ${ }^{94}$, ou seja, a aproximação superficial e inadequada para a concepção de arte exposta, ou ainda, mais provavelmente, podem gerar imprevistas formas de interação.

Para além do turismo, a arte na contemporaneidade tem lidado com essa interface em muitos outros âmbitos, ainda que de forma mal assumida. Os freqüentadores dos cursos de pintura relatam visitas a museus quando estão viajando: "Normalmente eu sempre vejo museus, tanto no Brasil quanto fora também, principalmente fora" [Aluna do Cultural Blue Life]. Supomos que este público acabe por ressignificar os museus de arte, adaptando tudo o que vê para uma concepção de arte própria. No fazer arte são inúmeros os cursos de pintura que alimentam essa vontade de ter momentos agradáveis. A procura por espaços coletivos para pintar, onde ocorrem muitas formas de sociabilidade,

\footnotetext{
${ }^{93}$ Cf. BRITO, R. “Pós, pré, quase ou anti?”. In: Experiência crítica. Organização de Sueli de Lima. São Paulo: CosacNaif, 2005.

${ }^{94}$ Termo utilizado por ARANTES, Otília. A expressão "fetiche invertido" é utilizada para explicar as relações que os novos museus estabelecem com seus públicos: os novos museus desconstroem a idéia que a arte neles exposta é destinada apenas para connaisseurs, proporcionando uma aproximação por meio de um consumo encenado e descartável. Ou seja, neste caso, troca-se o fetiche da arte pelo fetiche do consumo. "Os novos museus". Novos Estudos Cebrap, n. 31, 161-169, São Paulo, 1991, p. 162.
} 
também pode ser indicativa, já que contemporaneamente o prazer está fortemente associado às práticas em grupo (como shows, cinema etc.) em detrimento das atividades individuais e solitárias ${ }^{95}$.

No entanto, alguns alunos, no lugar de ressignificarem os locais institucionais, preferem procurar um circuito fora do circuito oficial, que dialoga diretamente com sua concepção de arte ao qual não precisa se adaptar:

"[...] Como eu gosto de passear na Praça da República, ver quadros, eu vi o quadro do Emip e tinha aquele verde [...] olha eu já visitei um museu, mas faz, olha, já faz muito tempo, e eu achei muito esquisito, porque era tudo tipo abstrato e sabe, eram uns garranchos [ao ser perguntada sobre se já havia visitado o Masp]. Sabe que eu nunca fui lá? Eu passo perto para ir ao laboratório mais eu nunca fui lá" [Aluna do Fruto da Arte]

Nãoé de se estranhar, assim, a preferência pela Praça da República aos museus, pois a praça propõe o diálogo mais direto com sua concepção de arte. Na praça, até a presença do pintor ao lado da obra facilita maior aproximação com os artistas e uma maior sociabilidade. Lá, ela pode perguntar ao próprio artista sobre o seu trabalho. A divisão social do trabalho artístico (críticos, marchands, curadores) inexiste na Praça da República, onde o expositor é o próprio artista, que também estabelece a mediação da obra com o seu público.

Uma relação oposta à da Praça da República é proposta pelos museus, que convidam ao olhar desinteressado para a arte, ao distanciamento do esteta moderno, interessado no que a arte significa em si mesma, o que muitas vezes pode afastar um público que se interessa por arte, como mostra Bourdieu:

Igualmente, cuando la investigación formal llega a insinuarse

${ }^{95}$ WALKER, J. A.; CHAPLIN, S. Una introducción a la cultura visual. Barcelona: Octaedro, 2002, p. 197. 
en sus espectáculos familiares - como ocurre en las variedades televisivas con los efectos especiales a lo Averty -, los espectadores de las clases populares se sublevan, no sólo porque no sienten la necesidad de estos juegos puros, sino por que a veces comprenden que los mismos obtienen su necesidad de la lógica de un cierto campo de producción que, por medio de estos juegos, les excluye [...]. ${ }^{96}$

Para Bourdieu, as classes populares não se interessam por esses “jogos puros”, porque não sentem a necessidade deles, que se referem a um outro campo de produção. As considerações de Bourdieu ${ }^{97}$ partem de uma pesquisa muito local. Para ele, isso seria uma disposição popular, associada a um estrato social mais baixo (material ou simbólico), o que não corresponde exatamente ao que observamos. Alunos que pertencem a um estrato social mais elevado, que possuem uma trajetória de "boa educação", também demonstram um descontentamento em relação a algumas mostras artísticas, como a Bienal, o que não significa, neste caso, uma atitude de falta de acesso ou privação cultural, mas sim uma atitude de escolha e intenção precisa: simplesmente adotam uma concepção de arte diferente. Muitos freqüentam museus (e não citam a Praça da República), mas nem por isso estão integralmente de acordo com as propostas de arte destas instituições, e nesse caso, são conscientes disso:

“Adoro o Emil Nolde, adoro os expressionistas de forma geral,
porque o meu trabalho tem muito disso, de se colocar... Agora
esta arte muito moderna eu não gosto, esse tipo... de
instalação, ou arte que é só uma mancha, eu não consigo
sentir emoção. Arte é aquilo que eu olho e me arrepia, que eu
sinto uma emoção. [...] Recentemente eu fui ver o Xul Solar,
eu fui ficando agoniada, mas eu senti uma emoção, mesmo se

\footnotetext{
${ }^{96}$ BOURDIEU, P. La distinción: critério y bases sociales del gusto, op. cit., p. 31.

${ }^{97}$ Ainda que os questionários de Bourdieu, que ele aplica para chegar a estas conclusões, pareçam muito restritos, como por exemplo a análise da pergunta: "Com qual dos seguintes temas você acha que o fotógrafo tem mais possibilidades de fazer uma foto, nas categorias: bela, interessante, insignificante ou feia? Uma paisagem, um acidente de carro, uma criança brincando com um gato, um pôr de sol sobre o mar, [...]" entre outros temas apresentados.
} 
for uma emoção de se sentir presa, transmitiu alguma coisa. Agora quando fui à Bienal de Veneza, sabe ver tudo e... não consegui achar graça naquilo” [Aluna Israel]

Pelos hábitos culturais deste grupo, podemos notar uma distinção entre pessoas que possuem uma mesma concepção de arte, da qual poderíamos supor dois extremos:

\section{TABELA 5: Arte como expressão}

\begin{tabular}{|c|c|}
\hline Tipos & Indicadores \\
\hline $\begin{array}{c}\text { Visão de expansão (ou } \\
\text { aperfeiçoamento) }\end{array}$ & $\begin{array}{c}\text { Busca de valores, emoções e sentimentos que estão além da vida } \\
\text { cotidiana ou real. Relativismo no julgamento: "tudo que é expressão } \\
\text { é arte". }\end{array}$ \\
\hline Visão instrumental & $\begin{array}{c}\text { Busca da ordem, da harmonia, a estabilidade, transpondo para a } \\
\text { pintura uma série de valores presentes na sua vida. } \\
\text { A pintura como uma forma de alívio, de relaxamento da tensão } \\
\text { nervosa ou indução de um estado emocional. } \\
\text { Escolha por temas afáveis, flores ou naturezas mortas (que } \\
\text { remetem à vida doméstica), ou paisagens bucólicas. Usam as cores } \\
\text { na pintura de acordo com o modelo escolhido, ou para dar outro } \\
\text { "clima" à pintura. }\end{array}$ \\
\hline
\end{tabular}

Na visão instrumental predomina o que Bourdieu chama de estética popular, que se caracteriza por vivências artísticas que buscam aproximar arte e vida, distantes de vivências artísticas que remetem somente ao universo de sua própria linguagem. Com base nessa estética, que reconhece o belo em relação ao tema representado, que busca legibilidade, que tem a função de agradar e de sensibilizar, veja como uma aluna descreve a ação do artista:

${ }^{98}$ OSBORNE, H. op. cit, p. 226. 
"Parte tem que ter uma sensibilidade muito grande para perceber, para sentir, para se envolver com aquilo que é belo. $A$ arte na verdade é a revelação do belo, tem que ter essa sensibilidade para projetar, para sentir o que se está fazendo" [Aluna do Fruto da Arte]

Por outro lado, não negamos a presença de outras disposições estéticas neste grupo, em que se mesclam intenções de arte como conhecimento e arte como fazer, e que - apenas - destacavam a expressão como princípio predominante do ato de pintar. E estão presentes neste grupo pessoas que visitam museus e se relacionam parcialmente com a arte legitimada, substituem critérios de ordem e harmonia por qualquer outro que "arrepie" ou emocione, o que justifica também a preferência por pintores expressionistas em alguns casos, ou um certo relativismo em outros (ao manifestar que gosta de tudo que é pintura, tudo o que é expressão, por exemplo). Para esse grupo, os procedimentos de pintura partem de uma busca subjetiva de um tema associado a uma memória pessoal ou outras associações livres. Assim, mesmo ao falar de um grupo que possui uma mesma concepção de arte, calcada na idéia de expressão, identificamos grande variável de procedimentos e temas perante a pintura.

\subsubsection{Arte como fazer}

No caso da pintura, a prática não é simples oposição à teoria. O fato de escolher cursos de pintura não é um indicativo óbvio de uma preferência por uma atividade artística prática. Alguns pintores se preocupam mais com o ofício de pintar e outros utilizam a pintura como um meio conceitual. Numa trajetória inversa, parte dos alunos dos cursos livres considera a pintura um fazer manufatureiro ${ }^{99}$, outros desejam construir pinturas que

\footnotetext{
${ }^{99}$ Prefere-se utilizar aqui o termo manufatureiro para escapar do termo artesanal, fruto da questionada oposição entre arte e artesanato, ou arte erudita e arte popular.
} 
sejam o reflexo do natural ou de um ideal de natureza. Nestes casos, a pintura cumpre uma função mais instrumental, ou está associada a uma visão naturalista de arte que se distancia muito da noção moderna de "Belas Artes", de produzir objetos para um fim exclusivamente estético. Segundo Osborne ${ }^{100}$, a arte possuiu uma função pragmática, em muitos períodos históricos, desde os escritos dos filósofos gregos acerca da manufatura e da techné.

\section{TABELA 6: Arte como fazer}

\begin{tabular}{|c|c|}
\hline Tipos & Indicadores \\
\hline $\begin{array}{c}\text { Visão naturalista } \\
\text { da arte }\end{array}$ & -Verossimilhança ilusionistica. \\
& $\begin{array}{c}\text { - Habilidades em realizar "truques" de representação (como dar } \\
\text { impressão de cobre, como dar brilho em uma gota). }\end{array}$ \\
Visão manufatureira & - Maior ênfase no tema representado. \\
& - Funcionalismo. \\
\hline
\end{tabular}

Muitas foram as regularidades observadas que evidenciam uma concepção da arte como técnica: em alguns casos, observa-se a ação de pintar motivada por um desafio técnico, evidenciado pelas expressões "fazer bem-feito", "chegar a uma pintura perfeita", entre outros termos que demarcam pontos objetivos de uma capacidade de fazer algo que pode ser claramente reconhecido. Muitas vezes o conteúdo que se expressa no tema não é tão importante, quanto o desafio que ele oferece: como "um quadro que parece um espelho" ou "uma gota que parece de verdade".

${ }^{100}$ OSBORNE, H. op. cit., p. 30. 
"Eu ganho experiências, você pode aperfeiçoar o que você já sabe, pode acrescentar. Por exemplo, ela me ensina a lidar com as cores, porque dependendo do estilo você tem que mesclar as cores. Por que aqui é uma orientação, mais aprofundada, ela explica, como se pinta uma flor" [Aluna do Blue Life].

"Eu sempre gostei de quadros, achava bonito, então eu quis ver se eu tinha, se eu era capaz de pintar. Foi um desafio para eu saber fazer isso. [...] Agora eu vou fazer assim, para eu enfatizar mais, reforçar o aprendizado, eu quero fazer um quadro aqui e reproduzi-lo em casa, para saber se sou capaz de fazer sozinha" [Aluna do Fruto da Arte].

"As técnicas: eu acho que para pintar nós precisamos de técnica... pelo menos para fazer uma pintura mais bem-feita, eu acho [...] Eu quero aprender a técnica, para fazer uma pintura perfeita" [Aluna do Espaço Cultural Blue Life].

"Eu me realizo, eu acho que me faz bem, eu olho para a tela e penso: Puxa vida, eu fui capaz de fazer (um desafio). Cada coisa que você pinta... não tem como explicar... A paisagem: a paisagem quando você começa, você sabe que é a sua mão, a tinta, você consegue trazer o realismo, quando você começa a dar brilho no rio e você fala, nossa como parece real, então aquilo começa a te satisfazer. As pessoas chegam à sua casa e dizem: Nossa que espelho que está isso e você se sente muito bem [...] e quando você faz a gota de água que você olha de longe e você vê que é uma gota... e você sabe que é o pincel, é a tua mão, é a tinta. Você fala: um pincel, uma tinta e você consegue fazer isso, fazer com tanto realismo, é muito gostoso" [Aluna de Eva Soares].

Esse interesse pela forma, pela técnica e procedimentos não deixa de ser também um interesse pela linguagem, ainda que aqui a atitude não se dá de forma "desinteressada", pelo contrário, a técnica está a serviço da eficácia, de fazer "bem-feito".

Predomina neste grupo um desejo ou o desafio de fazer uma pintura que pareça 
“real”. Nos casos mais extremos os conceitos como verossimilhança e imitação ${ }^{101}$ são inapropriados para a análise das práticas deste grupo, porque embora exista uma preferência pelo que se denomina “estilos naturalistas", na maioria dos casos não há uma relação direta com a natureza, já que as alunas utilizam como modelo outras pinturas ou fotografias. O que existe é um uso da arte semelhante ao que Harold Osborne ${ }^{102}$ chama de teorias naturalistas da arte, que correspondem a uma concepção de arte segundo a qual não há efetivo interesse na obra em si, mas sim pelo que ela representa. Osborne diz "Não incumbe às teorias naturalistas especular por que estamos interessados em ter cópias, embora se tenham aventado, às vezes, sugestões nesse sentido" 103 , ou seja, não existe distanciamento que permita pensar a arte pelo que ela representa por si mesma. A presença da reprodução e da cópia mostram que a individualidade do artista ou sua subjetividade não são determinantes, aliás, tampouco a relação com a natureza é exaltada. Aqui aparecem os critérios característicos do naturalismo como a correção e a capacidade de persuasão da representação.

"[...] eu compro a revista, vejo alguma coisa, tiro uma xerox colorida, depois modificamos alguma coisa [...] eu fiz um quadro de uns anjinhos pro meu neto" [Aluna do Fruto da Arte].

Em uma das escolas visitadas, "as figuras de referência", utilizadas como modelos para cópias, estavam agrupadas por níveis de dificuldade técnica, que variavam segundo os temas, e às vezes segundo a variação tonal das cores. Não é raro encontrar, especialmente dirigidos a esse público, manuais, revistas e vídeos que servem como receituários para a produção de pintura. $\mathrm{Na}$ Internet é possível achar uma infinidade de sites, nacionais e internacionais, que trazem a marca de uma concepção de arte semelhante. Veja-se o exemplo abaixo retirado da revista Arte em Tela, que coloca as cores utilizadas ao lado da pintura (guia de cores) como se fossem os ingredientes de uma receita para se copiar a pintura.

\footnotetext{
${ }^{101}$ Entendidas como fruto da experiência com o real segundo Aristóteles (Ver NUNES, B. op. cit., p. 57).

${ }^{102}$ OSBORNE, H. op. cit., p. 22.

${ }^{103}$ Ibidem.
} 


\section{thaisagens}

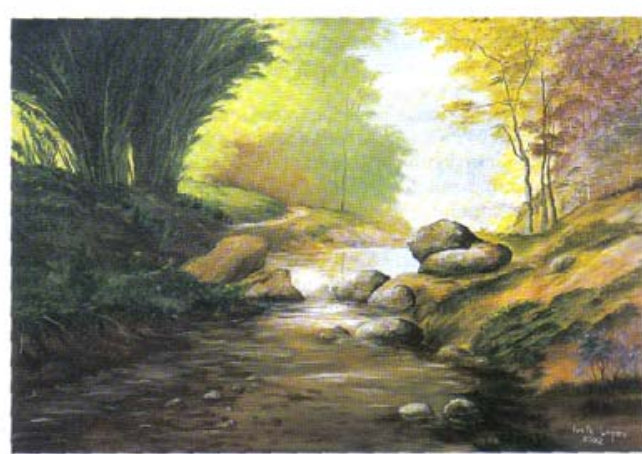

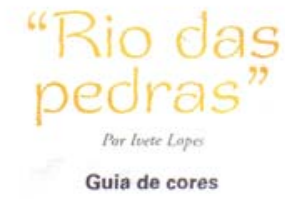

Céu : azul cerùleo, branco de titânio e Vegetaçâà do fundo: amarelo de cádmio, branco de titânio, amarelo ocree $e$ alaranjado de cádmic

Vegetaçáo em primeiro plano: verde vessie, amarelo ocre, alaranjado de cadimio, arnarelo de cadinio e torna de siena naturat

Dedras: matrom van dick, cor de pele, amarelo ocre, branco de titânio e

Informaçóes adicionais:
(11) 4191-3114

Também na mesma concepção podemos citar os cursos de pintura centrados em técnicas e suas variações, que refletem a forma pela qual organizam o conhecimento em pintura e não escondem a objetividade do que é ensinado, refletindo assim uma visão explicitamente pragmática.

\section{FIGURA 3: Prospecto do ateliê ICCLA}
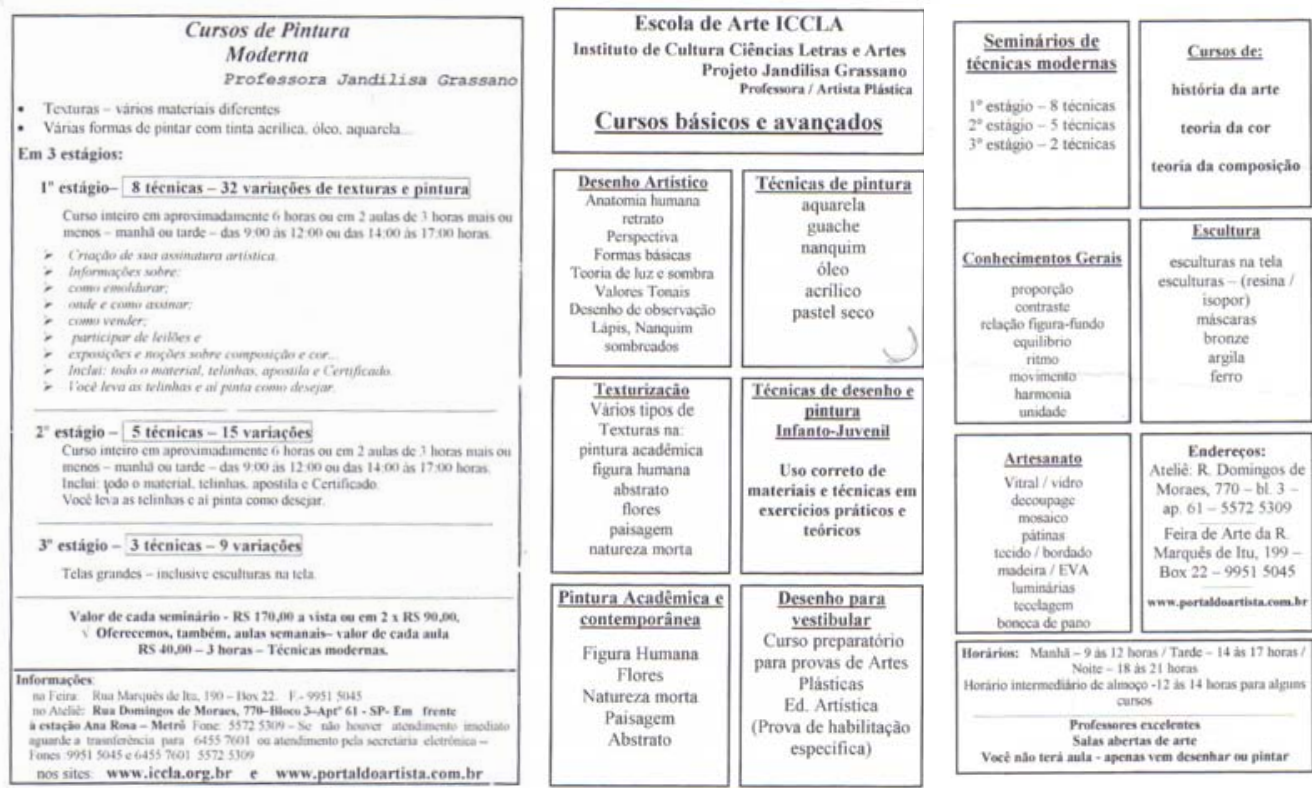
Esse interesse especial por “aprender a fazer bem", “o desafio" da manualidade na técnica da pintura, pode ser relacionado com o craft, a produção de artefatos. Rachel Mason $^{104}$ foi uma das poucas pesquisadoras a se interessar por estudar a arte como fazer e como manualidade. A autora mostra que a produção de artefatos é pouco estudada na atualidade, por ser considerada fora de moda no campo da arte-educação. A autora questiona que à medida que os currículos de arte da Grã-Bretanha deixam de lado as atividades manuais, estas paradoxalmente passam a aumentar muito nos lares da Inglaterra e inclusive tornam-se imensamente praticadas por jovens, de forma autodidata e amadora. O que a autora pergunta é: "Por que as pessoas decidem fazer crafts? Que benefícios e conhecimentos essa prática fornece?’.A autora sabe que está fazendo esta pergunta num contexto adverso, que nega o craft como arte, mas insiste em afirmar que existe sim certo desenvolvimento "estético" nessas práticas que se diferenciam de trabalhos manuais simples.

Para discutir esse assunto e para compreender a pintura como uma atividade de fazer, mais uma vez temos que evitar uma leitura purista, centrada somente nas teorias da arte que desconsideram na contemporaneidade os interesses pragmáticos e naturalistas. Para compreender as razões dessa prática, Mason, por exemplo, recorre às teorias das Famílias (family Teory), que usualmente interpretam atividades de decorar a casa, e outras do gênero, como representações do imaginário e ações de formatividade. Nessa perspectiva, a decoração da casa, por exemplo, é lida como uma espécie de instalação, um trabalho museográfico de representação da própria vida, uma forma de se comunicar socialmente através do arranjo e da escolha cuidadosa de objetos que representam e significam valores. Embora a mídia exerça uma influência sobre este tipo de artesania doméstica, na verdade ocorre uma apropriação de valores que podem ser encarados como uma mediação entre a mídia e a absorção pelo sujeito ${ }^{105}$. Vale lembrar que a apropriação e influência são igualmente aceitáveis no contexto legitimado de arte.

\footnotetext{
${ }^{104}$ MASON, R. "Meaning and Value of Home-based Craft". International Journal of Art and Design Education, n. 24, vol. 3, p. 256-268, 2005.

${ }^{105}$ FREEDMAN, K. op. cit.
} 
A autora afirma ainda que a experiência em arte ocorre de forma mais plural e ampliada do que no passado, em parte pelas mudanças sociais, em parte pela ampliação da tecnologia (que aumenta inclusive a possibilidade de práticas amadoras). Na mesma direção Larry Shiner chega a propor um "Terceiro sistema da arte"106, distante das polaridades entre arte e artesanato. Ele denuncia um apego ao sentido moderno da palavra "arte" que é inadequado para refletir tanto a arte pré-moderna quanto algumas práticas do presente. Ingenuamente procura-se manter a idéia moderna de arte, mesmo quando muitas práticas demonstram que ela está falida. ${ }^{107}$

Rachel Mason diz que a arte-educação, muito embora parta do princípio de uma relação dialógica com o aprendiz, ainda se prende a um modelo de arte muito elitista ocidental, o que dificulta ainda mais a compreensão e o desenvolvimento de uma série de práticas, que ficam renegadas ao contexto extra-escolar, extra-oficial, e, em alguns casos, restritas ao espaço doméstico. Em concordância, a maioria dos alunos de pintura que portam uma concepção de arte como esta são de escolas de pequeno porte, ou de cursos dados nas casas dos professores.

Contrários aos argumentos que embasam a teoria da "estética do cotidiano", muitos críticos e teóricos contemporâneos não negam que o exercício estético pode estar presente em outros âmbitos da vida, no entanto, a arte estaria relacionada a um exercício mais superior da contemplação estética, sustentado por objetos que transcendem a realidade, que propõem significados relativamente autônomos aos âmbitos da vida prática, ou minimamente estranhos a ela ${ }^{108}$. Por outro lado, hipoteticamente, é possível concluir que tal exercício possa surgir dentro das diversas concepções de arte, até das mais pragmáticas e se desdobrar posteriormente em formas mais complexas. Ressalta-se que algumas alunas iniciaram a prática artística após uma grande experiência com crafts, ou seja, a partir da manualidade (cursos de batique, de pintura em seda), passaram para a pintura e, em alguns casos, estenderam ou modificaram a sua concepção de arte, fazendo

\footnotetext{
${ }^{106}$ SHINER, L. La invención del arte - Uma historia cultural. Barcelona: Paidós, 2001, p. 30.

${ }^{107}$ Ibidem, p.41.

${ }^{108}$ OSBORNE, H. op. cit., p. 25.
} 
uma pintura que já não considerava a técnica como princípio único.

Outra característica observada foi que essas práticas, justamente pelo pragmatismo, fortalecem a pessoa quanto à imagem que constrói de si mesma, já que ela se sente realizada por conquistar pouco a pouco o desafio de pintar, uma das características de muitas atividades amadoras, como comentamos na introdução da pesquisa.

"Faz-me bem, é gostoso você receber elogios. Eu acho que pelo fato de eu não ter uma profissão, eu acho que a pintura me trouxe alguma coisa. Você corre atrás de uma coisa, não ter conseguido... e na pintura eu vi que tem alguma coisa de mim, que as pessoas olham e falam... Nossa a Sônia pintou! Então você se sente valorizada" [aluna de Eva Soares].

\subsection{Arte como conhecimento: $O$ distanciamento estético}

Para um grupo dos alunos dos cursos livres a arte não é um "caminho" para realizar outra coisa, a arte não é feita para expressar as próprias emoções, aprender a copiar a natureza, decorar ou desenvolver uma habilidade técnica. Alguns alunos dos cursos livres priorizam no fazer artístico a cognição, possuem distanciamento estético e fazem arte pelo conhecimento que a própria arte suscita.

Pareyson $^{109}$, para explicar a natureza do conhecimento adquirido por meio da prática artística, acabou por desenvolver a teoria da formatividade, de acordo com a qual o conhecimento da arte se constrói na relação com o fazer (mas aqui, não o fazer entendido como execução, mas como processo de pensar, inclusive a forma). Na formatividade, o pensar, o inventar, o produzir são inerentes à produção de um conhecimento. A arte, então, acaba por assumir uma autonomia e por produzir um conhecimento que requer distanciamento estético para seu desenvolvimento: um conhecer distinto, revelador de si mesmo.

${ }^{109}$ PAREYSON, L. op. cit., p. 33. 


\section{TABELA 7: Arte como conhecimento}

\begin{tabular}{|c|c|}
\hline Tipos & Indicadores \\
\hline Posição desinteressada & - Justifica o fazer artístico por ele mesmo. \\
& $\begin{array}{c}\text { - Não associam arte a nenhum prazer ou lazer, arte é } \\
\text { investigação. }\end{array}$ \\
& - A arte não tem utilidade alguma a não ser o conhecimento \\
& dela mesma. \\
\hline
\end{tabular}

Obviamente, este interesse de cognição aparece conjugado a outras funções, como a técnica, que aqui está a serviço de uma pesquisa da linguagem, e não de uma simples execução manual.

"Eu fico pesquisando muito as cores, aprofundando a pesquisa da relação de cores. A outra pesquisa é a história da arte. Também estou pesquisando novas formas" [Aluna da Teresa Viana].

O mesmo acontece em relação à função da expressão e da manifestação dos sentimentos, que não deixa de existir para os alunos interessados prioritariamente em fazer arte como conhecimento. Aqui o inconsciente e a subjetividade são convertidos em procedimento de investigação, em intuição e na forma de pesquisar:

"Eu acho que eu vou desenvolvendo o pensamento, vou desenvolvendo um outro tipo de intuição, com toda essa pesquisa, que faz parte até da parte psicológica da gente, você vai ficando mais aguçado para algumas coisas da vida [...] porque isso aqui é um exercício, aquela coisa que você vai tateando no escuro, e à medida que você vai tateando no escuro você vai descobrindo um tesouro, que jamais, você 
não faria conscientemente. Então acho que tem um desenvolvimento do ser humano que está ligado à prática artística. Você vai tateando, mas você vai descobrindo novas verdades, novas atitudes" [Aluna da Teresa Viana].

Como mostra o depoimento acima, alguns alunos dos cursos livres de pintura possuem essa relação de investigação da própria forma artística, numa relação em que não há regras que não sejam as pensadas no próprio processo de produção. Assim, a linguagem se relaciona não apenas a regras formais pré-existentes, mas também com a subjetividade que é expressa através do ato de produzir e fazer arte. Na produção da pintura articulam-se todas essas dimensões que propiciam uma pesquisa da linguagem. $O$ curso livre é apontado como o lugar privilegiado para o desenvolvimento desta pesquisa, já que nele não há um currículo previamente estabelecido, permitindo realmente o desenvolvimento inclusive de um currículo.

"Na realidade é uma coisa diferente, de um curso normal, para um curso livre: é que tudo que você faz tem uma notificação, é algo para ser notificado, não é algo muito espontâneo, você faz por uma obrigação, você precisa cumprir aqueles créditos, aquela coisa toda, e no curso livre, você vai atrás de algo que é seu. Algo que é a sua pesquisa, naquele momento, e sob a orientação de alguém que está te olhando em especial, coisa que na faculdade vai ao atacado, o cara dá uma geralzona. Eu tinha feito um curso com a Vera Martins no MUBE, mas parei porque mudei para Florianópolis. [...] Você sai da faculdade sem grandes aprofundamentos. Na graduação você aprende a ser malandro, a apresentar o que o professor gosta" [Aluna da Teresa Viana].

"Acho que na prática, levantando questões, e instigando eles a resolverem essas questões" [Aluna de Marcos Rossi].

Alguns freqüentadores dos cursos livres de pintura acabam por desenvolver uma formação bastante independente, que explicita uma trajetória em que o conhecimento 
em arte se constituiu ao longo da freqüência nos diferentes cursos livres. Por exemplo, uma aluna entrevistada realizava uma exposição individual resultante de sua trajetória de aprendizagem construída em diversos cursos livres: aquarela, figura humana (modelo vivo), sumi-ê, batique entre outros cursos que acabam por totalizar uma formação muito particular, construída pela própria aluna.

NARRATIVA VIUAL 5 : Percurso de uma aluna que faz arte como conhecimento
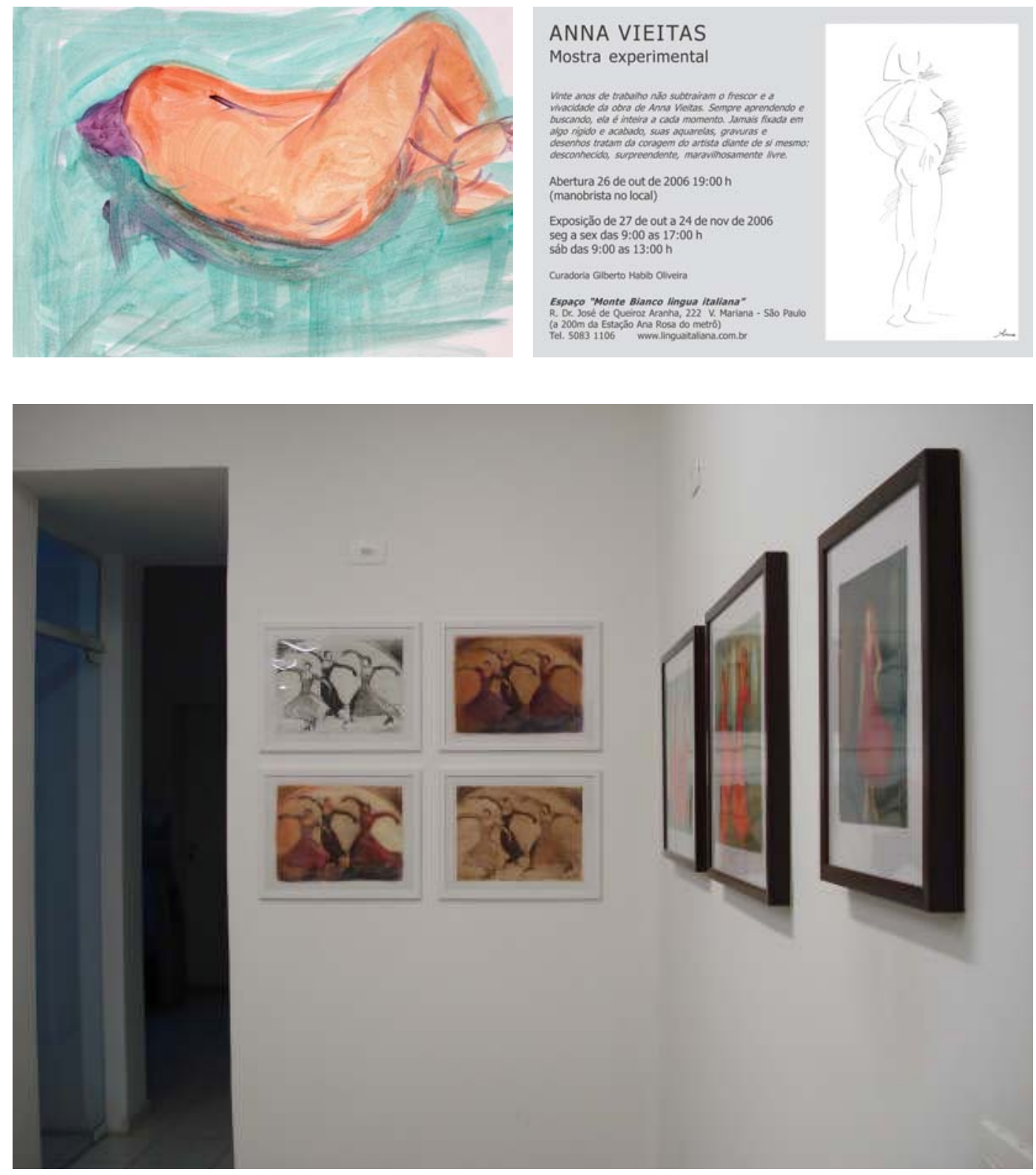

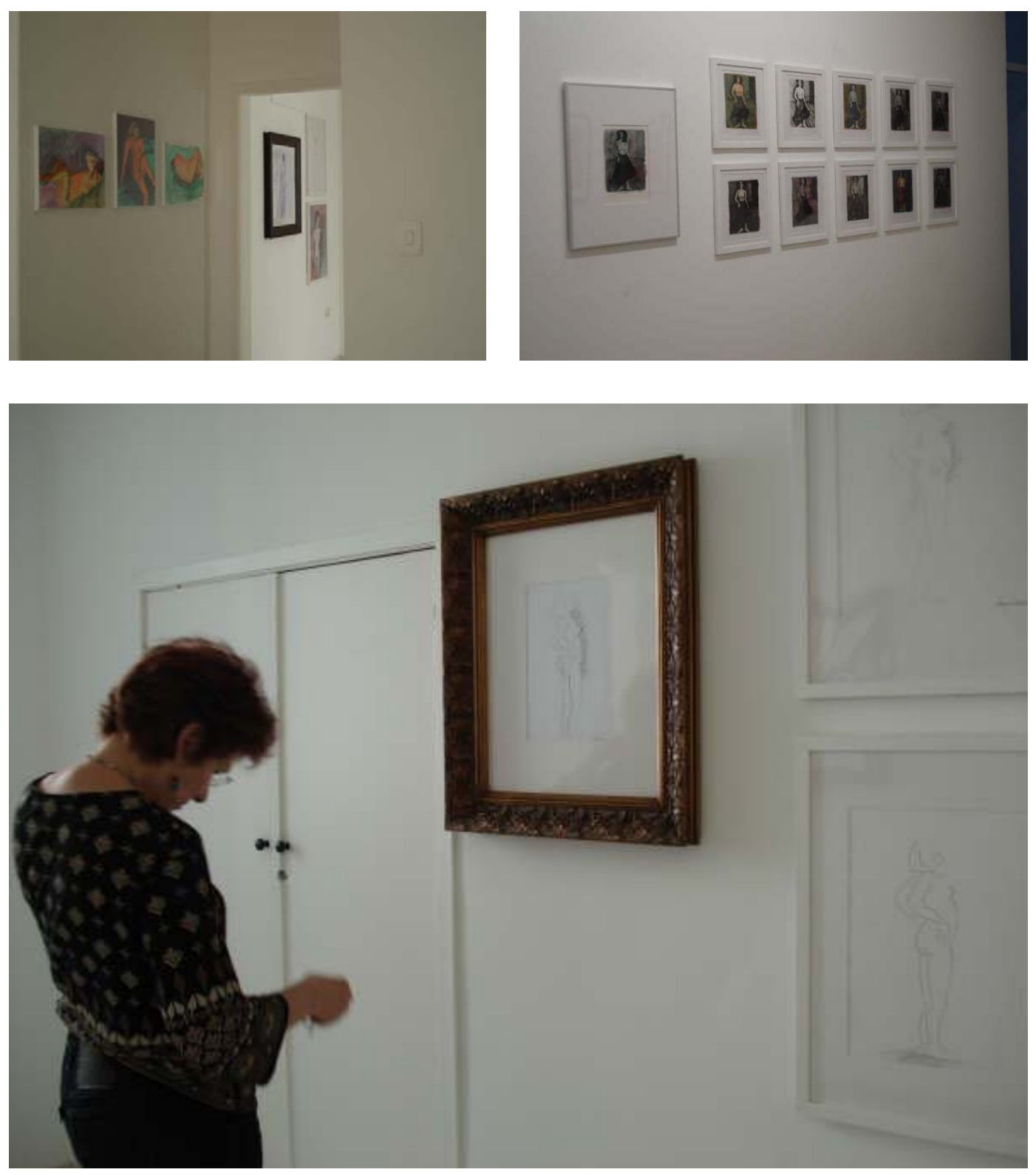

Em sua exposição a aluna surpreendeu pela maturidade adquirida em diferentes cursos livres. Em seu trabalho, com um tratamento que mescla transparências e densidade da aquarela, a composição com figuras humanas, que sangram e escapam do papel, enfatizam uma pesquisa aprofundada na linguagem. Ele ajuda a compreender como que muitas vezes seria difícil controlar as práticas dos cursos livres ou definir a prática a partir de uma concepção de arte estável. Em uma última conversa, a aluna revelou não freqüentar mais o curso livre, no qual a entrevistei, por achar que a ênfase nele estava muito em uma concepção de figuração e representação que está distante da sua. 
ESCRITOS DO MEIO IV

Instalações de arte, dança do ventre e musica evangélica 


\section{Instalações de arte, dança do ventre e música evangélica}

No período concomitante a elaboração desta tese lecionei num curso de Educação Artística, em um Centro Universitário da Grande São Paulo. Constatei que o estudo sobre usos e concepções de arte, dentro de um enfoque antropológico, era essencial também naquele contexto, em que as discussões sobre multiculturalidade deveriam constituir a matriz conceitual de um currículo de um curso superior de arte.

Na universidade em questão, notei que os usos da arte realmente praticados pelos alunos não coincidiam muitas vezes com as propostas do curso e dos professores. Um exemplo espantoso aconteceu na semana cultural do curso: uma programação dos alunos com apresentação de dança do ventre, banda evangélica de soul music, entre outros, provocava estranhamento ao corpo docente acostumado a falar de autonomia religiosa da arte e de uma arte majoritariamente ocidental. A relação dialógica estava lá, mas acontecia de forma espontânea e inconsciente; as práticas dos alunos se revelavam como táticas sorrateiras e informais, não sufocadas, mas tampouco consideradas no projeto pedagógico do curso, construído por um grupo de professores que muitas vezes lidavam com uma concepção única e universal de arte e esqueciam da relação curso/discentes.

Seguindo a indicação do próprio Chalmers*, o multiculturalismo poderia estar presente no currículo por meio da relativização da função e da concepção do que é arte. Neste caso, já significaria muito explicitar a concepção e os usos da arte como uma tomada de decisão curricular e não como um movimento natural.

*CHALMERS, F. G. Arte, educación e diversidad cultural. Barcelona: Paidos, 2003. 
CONCLUSÃO 


\section{Conclusão}

O desvelamento das práticas de apropriação e aproximação da arte aqui relatadas evidenciam que muitos projetos de arte que se querem "públicos" devem dialogar com concepções de arte efetivamente praticadas por públicos diversificados. A hipótese do trabalho, de que muitas concepções de arte coexistem na cidade de São Paulo, se confirmou a partir da pesquisa etnográfica nos cursos de pintura. Nestes, a prática da pintura tem múltiplas referências e carregam códigos culturais diversos. Com base na análise antropológica foi possível retomar e compreender melhor o conceito de hibridização de Canclini, que propõe um modelo estendido e não-dicotômico das diferenciações entre erudito, popular e massivo; além disso, o conceito de híbrido permite a fusão e a collage de diferentes concepções de arte que ora se baseiam em visões analíticas, ora em visões pragmáticas de arte. O hibridismo, nas práticas dos cursos livres de pintura, se revela na mescla de concepções de arte advindas tanto de concepções clássicas da arte quanto das que fogem desse âmbito. Por isso as práticas aqui relatadas estão no meio-fio, impregnadas de significados que não se revelam diante de um olhar purista.

Os variados usos da arte aqui relatados não são apenas uma questão entre centro e periferia, não estão vinculados aos diferentes estratos sociais, assim como a multiculturalidade não é apenas uma questão entre pessoas de diferentes lugares. No centro de uma cidade como São Paulo emergem práticas regidas por códigos ignorados, irreconhecíveis às instâncias legitimadoras e que, por obedecerem uma outra lógica, parecem fadadas ao periférico, ao subúrbio do centro, como afirmaria Lyotard ${ }^{110}$. Compreender outra lógica cultural pressupõe aceitar questionar estruturalmente o conceito de arte, para,

${ }^{110}$ LYOTARD, J. F. Moralidades pós-modernas. Campinas: Papirus, 1996. 
a partir do diálogo estabelecido, estender a compreensão de arte na contemporaneidade. Assim, por exemplo, a simples instalação de equipamentos culturais públicos não garante o diálogo se ocorre ao largo do que anseiam as pessoas interessadas em formas de aproximação com a arte, diferentes das propostas institucionais.

Desconectadas da concepção de arte contemporânea legitimada, algumas das práticas pensadas nesta tese só puderam ser compreendidas mediante uma perspectiva da antropologia cultural e das teorias da Cultura Visual, que abrangem muitos estudos de gênero e da estética do cotidiano ${ }^{111}$. Esses campos do conhecimento oferecem a possibilidade de observar as práticas artísticas sem os preconceitos da historiografia da arte, edificados sobre uma narrativa linear, sem espaço para práticas não-coerentes a tais estruturas. As teorias da arte são pensadas em relação a contextos culturais específicos, assim como a história da arte pressupõem escolhas e tomadas de posições que, se não explicitadas, são interpretadas como permanentes e totalizadoras, dificultando a compreensão de práticas artísticas que estão para além destas. Por isso, esta pesquisa utiliza um amálgama de teorias e construções teóricas que pontuam e defendem o relativismo do conceito de "arte"112, e que não estão distantes das discussões estéticas contemporâneas.

A partir do enfoque filosófico e lingüístico, tendências da estética do século XX passaram a negar qualquer forma sistemática de afirmar ou definir o conceito de "arte" ou "beleza" "113. Por meio desse enfoque passa a ser inócuo procurar a essência do conceito de arte, que ao longo da história reuniu diversas aplicações genéricas e transferências de significado muito mais lingüísticas do que relacionadas aos "usos" da própria arte.

A concepção do estético na contemporaneidade, segundo a ideologia dominante, distante de qualquer pragmatismo, prefere discutir a arte a partir da própria história e não a partir das práticas artísticas, esquecendo a tensão necessária (entre experiência e

\footnotetext{
${ }^{111}$ Também apareceram ao longo da pesquisa algumas autoras brasileiras que ousaram trazer essa discussão à tona, como Ivone Mendes Richter, na Arte-Educação; e Maria Lucia Montes, na História e na Crítica de Arte.

${ }^{112}$ OSBORNE, H. op. cit., p. 236-237.

${ }^{113}$ Ibidem.
} 
pensamento) para a reflexão cultural. Ignora-se muitas vezes que a filosofia e a estética não são somente pura abstração, mas alimentam-se e renovam-se graças aos problemas que são suscitados pela experiência ${ }^{114}$. Após uma pesquisa como esta, ao menos pode-se nomear como "lacuna" o desconforto que qualquer artista formado pelas instituições formais e legitimadas sente ao caminhar numa feira de arte, como a da Praça da República.

Finalmente, pulsam teorias e pesquisas que clamam por uma visão mais pragmática da arte, tentando novamente compreendê-la dentro de um contexto social e cultural, como os estudos de Shusterman ${ }^{115}$. Na mesma direção, os estudos multiculturais com seu "relativismo" permitem a desconstrução (e a collage) que nega uma narrativa histórica da arte demasiada homogênea e unificada. Ao vislumbrar outros contextos históricos e outras práticas artísticas distantes ou sobrepostas à ideologia dominante, esses estudos oferecem subsídios para a compreensão de práticas de aproximação ou de fazer arte "reais". Os estudos sobre multiculturalidade assumem essa marca do relativismo ao recorrer ao princípio do uso que se faz da arte e não a uma essência, ingênua e genérica, dela.

A aproximação das reflexões sobre a diversidade artística depende desse relativismo do conceito de "arte", que varia de acordo com momentos históricos e diferentes contextos. Ressalta-se que a interculturalidade ${ }^{116}$ não é só étnica, mas, como aconteceu nesta pesquisa, refere-se a um uso da arte, causado por questões de gênero, ou outros elementos provenientes da trajetória de vida cultural e do imaginário cultural dos amadores da arte. Danto ${ }^{117}$ chama o momento em que vivemos de um momento de arte pós-histórica, em que seguir a linearidade da história da arte ocidental, na sua sucessão de rupturas e descobrimentos, é inócuo. Para Danto, também a arte está mais que nunca influenciada

\footnotetext{
${ }^{114}$ PAREYSON, L. op. cit., p. 19.

${ }^{115}$ SHUSTERMAN, R. op. cit.

${ }^{116} \mathrm{O}$ termo é empregado como uma opção ao multicultural ou à pluralidade cultural, por representar melhor a idéia de reciprocidade. O termo interculturalidade é colocado por Ana Lúcia E. F. VALENTE (Apud RICHTER, 2003, p. 20). Cf. RICHTER, I. M. Interculturalidade e Estética do Cotidiano no Ensino das Artes Visuais. Campinas: Mercado de Letras, 2003.

${ }^{117}$ DANTO, A. C. Más allá de La Caja Brillo: las artes visuales desde la perspectiva posthistórica. Madrid: Akal, 2003, p. 24.
} 
por outras esferas da vida cotidiana, que não somente as esferas da arte. Em uma metrópole como São Paulo, muitas vezes diferentes locais e tempos históricos estão sobrepostos. Por isso, cada escola, ainda que na mesma região, representou uma etnografia com grande diversidade cultural, que resultariam numa historicidade da arte bastante alinear.

Mas, ao afirmar que muitas pessoas fazem arte na cidade de São Paulo, orientadas por tão distintas intenções, o que se pode propor? Qual o caminho a seguir? A intenção da pesquisa consiste mais em evidenciar a existência dessa multiplicidade do que em apontar propostas culturais. Mas também carrega deste seu princípio a inquietação diante de uma enorme distância entre a arte aprendida na universidade e a arte vivida no cotidiano da cidade ${ }^{118}$, carente de uma resposta consistente em face das afirmações e reclamações sobre a ausência de público de arte. Ou ainda, na desilusão com propostas sociais, artísticas e educativas de arte, que parecem sapatear no vazio ao não estabelecer uma relação dialógica com grande parte da população que pensa e deseja se relacionar com arte sob outra perspectiva.

Estabelecer um diálogo entre concepções tão distintas de arte não significa submeter-se a essas visões, tampouco dominá-las. A visão dicotômica entre dominante e dominado não serve ao modelo de interculturalidade. Um caminho possível é o da extensão desses diferentes códigos que podem coexistir (sorrateiramente já convivem como táticas). Admitir a existência de outras formas de se relacionar com arte é um passo inicial para se pensar em propostas educativas e culturais que de fato considerem esses valores. Estender o que se entende por "público de arte" é urgente. O contexto cultural e as práticas dos sujeitos não deveriam ser desconsiderados nem nas escolas, nem nas instituições de disseminação da arte (tais como centros culturais e museus).

Neste caso, de alunos de cursos de pintura, a discriminação centra-se nas questões de gênero e faixa etária, já que a maioria dos praticantes eram mulheres com idade acima de 60 anos e carregam concepções de arte consideradas anacrônicas: arte

\footnotetext{
${ }^{118}$ Reiteramos que a chispa inicial da pesquisa nasceu no complexo pólo de materiais artísticos no entorno da feira de arte da Praça da República.
} 
como expressão dos sentimentos e arte como fazer. Essas mulheres podem representar o avesso da crítica e da história da arte pois provam que muitas práticas artísticas não respeitam as normas institucionais e sobrevivem nos espaços informais, sem responder aos valores homogêneos e androcêntricos ${ }^{119}$. Essas alunas também poderiam ter suas práticas e concepções estendidas caso houvesse um diálogo verdadeiro entre suas reais intenções perante o fazer artístico e outras propostas institucionais. Muitas das mulheres entrevistadas são levadas a procurar um circuito bastante informal (como das escolas de pequeno porte) para poder praticar a arte de acordo com a concepção que elas têm de arte, e com o modo que anseiam essa prática. No entanto, vale enfatizar que, apesar de terem suas "vontades ignoradas", muitas dessas pessoas se apropriam de espaços instituídos e conseguem de forma autônoma reconstruir nestes uma prática díspar (como constatamos nos casos do MAM-SP e do Instituto Tomie Ohtake), ou seja, às vezes criam-se dispositivos de adaptação. ${ }^{120}$

As práticas observadas estão perfeitamente ajustadas ao contexto de pessoas, que são portadoras de imaginários culturais diversos, com um repertório cultural constituído a partir de circuitos diversos e trajetórias particulares, com influência da mídia, do espaço doméstico entre outros. Se existe um desajuste, ele se dá em relação às idéias instituídas e legitimadas sobre o que significa fazer arte. Mas se considerarmos que o cenário dessas práticas é o do centro de uma metrópole, local privilegiado para a diversidade, mescla entre o antigo e o moderno, entre o bom e o "mau” gosto (seja lá o que possam significar),

\footnotetext{
${ }^{119}$ A antropóloga e Profa. Dra. Maria Lúcia Montes oferece-nos exemplos de como os críticos de arte desconsideram temáticas do imaginário feminino. O caso mais notório é o da artista Tarsila do Amaral, que tem sua fase de produção posterior aos anos 30 postulada como decadente justamente por retornar à uma temática intimista e doméstica. MONTES, M. L (org.). Mulheres pintoras: a casa e o mundo. São Paulo: Pinacoteca / Sociarte, 2004 (Catálogo de exposição).

${ }^{120}$ Também, alguns museus e/ou centros culturais intencionalmente propõem atividades ou cursos levando em conta esse diálogo tornando tal contribuição visível. Podemos citar os cursos de pintura oferecidos para a terceira idade pelo MAC-USP, coordenados por Sylvio Coutinho e também algumas oficinas do SESC (no caso, acompanhei a oficina de aquarela de Gilberto Habib), dois exemplos de cursos que conseguem mesclar diferentes concepções de arte, que, menos herméticos, ampliam o leque de conceitos estéticoe para um público interessado em arte, considerando diferentes necessidades e dialogando com as concepções de arte do alunado.

${ }^{121}$ MAGNANI, J. G. C.; TORRES, L. de L. (orgs.), op. cit., p. 21.
} 
essas práticas não são anacrônicas. Conflui-se, assim, à visão da antropologia urbana ${ }^{121}$ ao afirmar que não há nada de exótico ou anormal em haver noções e concepções de arte tão distintas num cenário de uma metrópole como São Paulo; estranho seria não querer admitir ou compreender isso, face à polifonia inerente que a permeia. 
BIBLIOGRAFIA 


\section{Livros}

ALMEIDA, C. M. C. A. O trabalho do artista plástico na Instituição de Ensino Superior: Razões e paixões do artista professor. 1992. Tese de Doutorado (em Educação). Campinas: Universidade de Campinas (Unicamp).

ARSLAN, L. M. O artista que sobrevive: Incursões profissionais de artistas plásticos formados no início do novo milênio. 2002. Dissertação de Mestrado. São Paulo: Universidade Estadual Paulista (Unesp).

BASBAUM, R. (org.) Arte contemporânea brasileira. Rio de Janeiro: Rios Ambiciosos/Contracapa, 2001.

BATTCOCK, G. (org). A nova arte. São Paulo: Perspectiva, 1975 (Coleção Debates, n. 73).

BERGER, P. Perspectivas sociológicas: uma visão humanística. Petrópolis: Vozes, 1986.

BOURDIEU, P. “Uma ciência que perturba. Entrevista a Pierre Thuillier”. In: Questões de Sociologia. Rio de Janeiro: Marco Zero, 1980.

. La distinción: critério y bases sociales del gusto. Madrid: Taurus Humanidades, 1988.

. A produção da crença: contribuição para uma economia dos bens simbólicos. São Paulo: Zouk, 2002

Creencia artística y bienes simbólicos: elementos para uma sociología da cultura. Buenos Aires: Aurelia Rivera Grupo Cordoba y Buenos Aires, 2003.

A economia das trocas simbólicas. São Paulo: Perspectiva: 2004. 
. \& HAACKE, H. Livre-troca. Diálogos entre ciência e a arte.

Rio de Janeiro: Bertrand Brasil, 1995.

.\& DARBEL, A. O amor pela arte: Os museus de arte na Europa e seu público. São Paulo: Edusp/Zouk, 2003.

BRANDÃO, Z. “A teoria como hipótese. Conversas com pós-graduandos. Entre questionários e entrevistas". In: Pesquisa em educação - conversas com pósgraduandos. Rio de Janeiro: Loyola/PUC-RJ, 2002.

BUENO, M. A. Artes plásticas no século XX: modernidade e globalização. Campinas: Editora da Unicamp, 1999.

CANCLINI, N. G. Culturas hibridas: estratégias para entrar e sair da modernidade. São Paulo: Edusp, 2003.

. Diferentes, desiguales y desconectados : mapas de la interculturalidad. Barcelona: Gedisa, 2004.

. A socialização da arte - teoria e prática na América Latina.

São Paulo: Cultrix, 1980.

. Consumidores e cidadãos: conflitos multiculturais da globalização. Rio de Janeiro: Editora da UFRJ, 1995.

CERTEAU, M.de A invenção do cotidiano. Petrópolis: Vozes, 1994.

CHALMERS, F. G. Arte, educación e diversidad cultural. Barcelona: Paidos, 2003.

CHAUÍ, M. S. Cultura e democracia: o discurso competente e outras falas. São Paulo: Moderna, 1981.

CHILVERS, I. Dicionário Oxford de Arte. São Paulo: Martins Fontes, 2001. COLLINGWOOD, R. G. Los principios del arte. México: Fondo de Cultura Económica, 1960.

CUNHA, N. Dicionário SESC: A linguagem da cultura. São Paulo: Perspectiva/SESC, 2003. 
DANTO, A. C. Após o fim da arte. A arte contemporânea e os limites da história. São Paulo: Edusp, 2003.

- Más allá de la Caja Brillo: las artes visuales desde la perspectiva posthistórica. Madrid: Akal, 2003.

DORFLES, G. El kitsch: antologia del mal gusto. Barcelona: Editorial Lumen, 1973.

DUMAZEDIER, J. Sociologia empírica do lazer. São Paulo: Perspectiva, 1979.

DURAND, J. C. Arte, privilégio e distinção: artes plásticas, arquitetura e classe dirigente no Brasil, 1955-1985. São Paulo: Perspectiva/Edusp, 1989.

ECO, U. Apocalípticos e integrados. São Paulo: Perspectiva, 1993.

EFLAND, A.D. A History of Art Education: Intellectual and Social Currents in Teaching the Visual Arts. New York: Teachers College Press, 1989.

FABBRINI, R. N. A arte depois das vanguardas. Campinas: Ed. da Unicamp/ Fapesp, 2002.

FOUCAULT, M. Ditos e escritos, v. I-II. Org. Manoel Barros da Motta. Rio de Janeiro: Forense Universitária, 2001.

GIESZ, L. Fenomenologia del kitsch: Una aportación a la estética antropológica. Barcelona: Tusquets, 1973.

GOFFMAN, E. A representação do eu na vida cotidiana. Petrópolis: Vozes, 1989.

GREENBERG, C. Vanguardia y kitsch. In : El Kitsch: antología del mal gusto. Barcelona: Editorial Lumen: 1973.

GRINSPUM, D. Educação para o patrimônio: museu de arte e escola responsabilidade compartilhada na formação de públicos. 2000. Tese de Doutorado. São Paulo: Faculdade de Educação da Universidade de São Paulo.

JAMESON, F. Pós-modernismo: a lógica cultural do capitalismo tardio. São Paulo: Ática, 1996. 
KRIS, E.; KURZ, Otto. La leyenda del artista. Madrid: Cátedra, 1995.

LIOSA. M. V. Tia Júlia e o Escrevinhador. Rio de Janeiro: Nova Fronteira, 1977.

LUNA, S. V. de. "O falso conflito entre tendências metodológicas". In: Cadernos de Pesquisa, n. 66, São Paulo: FCC/Cortez, p. 70-74, 1988.

LYOTARD, J. F. Moralidades pós-modernas. Campinas: , 1996

MAGNANI. J. G. C. Mystica urbe: Um estudo antropológico sobre o circuito neo-exotérico na metrópole. São Paulo: Studio Nobel, 1999.

; TORRES L. de L. (orgs.). Na metrópole. Textos de antropologia urbana. São Paulo: Edusp/Fapesp, 2000.

MASON, R. Por uma arte-educação multicultural. Campinas: Mercado de Letras, 2001.

MICELI. S. Imagens negociadas. São Paulo: Companhia das Letras, 1996. . Intelectuais à brasileira. São Paulo: Companhia das Letras, 2001. . Nacional estrangeiro: história social e cultural do modernismo artístico em São Paulo. São Paulo: Companhia das Letras, 2003.

MILLS, W. A imaginação sociológica. Rio de Janeiro: Zahar, 1965.

MONTES, M. L (org.). Mulheres pintoras: a casa e o mundo. São Paulo: Pinacoteca / Sociarte, 2004 (Catálogo de exposição)

NUNES, B. Introdução à filosofia da arte. São Paulo: DESA/Edusp, 1966 (Coleção Buriti).

NUSSBAUMER, G. M. O mercado da cultura em tempos (pós) modernos. Santa Maria: Editora da Universidade Federal de Santa Maria, 2000.

O'DOHERTY, B. No interior do cubo branco: a ideologia do espaço da arte. São Paulo: Martins Fontes, 2002.

OSBORNE. H. Estética e teoria da arte. São Paulo: Cultrix, 1993.

PAREYSON, L. Os problemas da estética. São Paulo: Martins Fontes, 1989. 
RICHTER, I. M. Interculturalidade e estética do cotidiano no ensino das artes visuais. Campinas: Mercado de Letras, 2003.

SETTON, M. G. J. Rotary Club: habitus, estilo de vida e sociabilidade. São Paulo: Annablume, 2004.

SHINER, L. La invención del arte. Una historia cultural. Madrid: Paidós, 2001.

SHUSTERMAN, R. Vivendo a Arte: O pensamento pragmatista e a estética popular. São Paulo: Editora 34, 1998.

SQUEFF, E.; SIMÕES E. Kislansky - o eterno e o moderno. São Paulo: Editora San Floro, 2006.

STRINATI, D. Cultura popular: uma introdução. São Paulo: Hedra, 1999.

STEBBINS, R. Amateurs, professionals and serious leisure. Montreal: McGill-Queen's Univesity Press, 1992.

SPOSATI, A. Cidade em pedaços. São Paulo: Brasiliense, 2001.

WALKER, J.A. y CHAPLIN, S. Una introducción a la cultura visual. Barcelona: Octaedro, 2002.

WITTGENSTEIN, L. Investigações filosóficas. México: Instituto de Investigações Filosóficas UNAM, 1988.

\section{Dicionários}

Dicionário Michaelis Digital.

\section{Documentos de acesso exclusivamente digital}

<www.espacocoringa.com.br>. Acesso em 14/08/2005.

$<$ www.escolarecriarte.com.br>. Acesso em 12/08/2005. 
$<$ www.evasoares.com.br>. Acesso em 12/08/2005.

\section{Artigos de revistas e jornais acadêmicos}

BROCKMEIER, J. “Autobiographical time”. Narrative Inquiry, n. 10, v. 1, p. 51-74, 2000.

DELEUZE, G. “Qu'est-ce qu'un dispositif?”. Rencontre Internationale: Michel Foucault Philosophe. Seuil: Paris, p. 185-194, 1989.

MASON, R. "Meaning and Value of Home-based Craft". International Journal of Art and Design Education, n. 24, v. 3, p. 256-268, 2005.

HERNÁNDEZ, F. “¿De qué hablamos cuando hablamos de cultura visual?” Educação e Realidade, n. 30, v. 2, p. 9-34, 2005. . "La construcción permanente de un campo no disciplinar". $L a$ Puerta. Publicación de Arte y Diseño, n. 2, p. 87-97, 2006.

KERRY, F. "Curriculum Inside and Outside School: Representations of Fine Art in Popular Culture”. International Journal of Art \& Design Education, n. 16, v. 2, p. 137-145, 1997.

TAVIN, K. M. "Wrestling withAngels, Searching for Ghosts: Toward a Critical Pedagogy of Visual Culture”. Studies of Art Education, n. 44, v. 3, p. 197-213, 2003 
APÊNDICE A

Diário da Pesquisa 


\section{Diário das entrevistas e visitas às escolas de pintura - outras anotações sobre os bastidores e reflexões soltas da tese.}

A construção de um diário das entrevistas iniciou-se para sanar a necessidade de registrar as primeiras impressões das entrevistas. Uma escrita mais livre, próxima à dos diários, alimenta e apresenta pistas, corroborando análises sistematizada das entrevistas.

Não posso negar a influência do Livro Tia Júlia e o Escrevinhador, onde o autor, Vargas Llosa, alterna sua narrativa com uma novela bastante vulgar e popular. Ele cria, neste livro, uma interface entre duas histórias e consegue transitar entre duas linguagens literárias distintas: uma mais popularesca e a outra erudita. Mesmo sem saber se teria habilidade para utilizar um formato tão criativo como o proposto em uma obra literária como esta, resolvi, em certa altura da pesquisa, fazer este diário de forma também disciplinada, intencionando, mesmo que em sonho, utilizá-lo ou incorporá-lo ao corpo da tese.

É importante ressaltar que a transcrição da maioria das fitas/ entrevistas seria feita em um momento posterior, assim o diário teria grande importância na rememoração de algumas situações que permearam as entrevistas. Também este diário foi tendo uma dimensão maior e se tornou um diário da tese, incluindo questões operacionais como o custo do trabalho etc.

Mesmo correndo o risco de um passo egocêntrico, lembrei-me das aulas com as professoras Maria da Graça Setton e Claudia Pereira Vianna (ambas da Faculdade de Educação da USP) onde discutíamos a pouca 
transparência que temos do processo dos pesquisadores. Por exemplo, nunca sabemos quanto tempo dedicam ao estudo de um livro, ou mesmo como o fazem. As questões operacionais de um processo de pesquisa ficam muito privadas, mas podem interessar aos estudantes que precisam aprender os procedimentos de um oficio como o de pesquisador.

Ainda que o meu processo de estudo seja bem pouco exemplar, achei que tinha obrigação de explicitar o dia-a-dia do pesquisador a futuros estudantes. O não ocultamento das questões operacionais do meio acadêmico, desmistifica o trabalho de pesquisa e torna-o menos mágico.

\section{Dia 15 de setembro de 2005: visita ao Collegio das Artes}

Logo após estar no Collegio das Artes, fiquei horas refletindo sobre o que ouvi e vi, em estado de graça/choque.

O maior impacto que tive foi em relação à qualidade que encontrei nas pinturas dos alunos: não pareciam pinturas feitas por iniciantes. Embora alguns alunos tivessem apenas um ano de curso, faziam telas enormes, com uma figuração abstraída, ou pinturas abstratas que discutiam relações mais formais da linguagem da pintura como forma e cor.

Fiquei impressionada com a orientação do artista, o Paulo Whitaker, que era muito pessoal. Aparentemente desprovida de um planejamento, no sentido tradicional, a sua aula não tinha um objetivo pré determinado, percebiase que ele orientava os alunos à medida em que o solicitavam. O professor olhava, fazia comentários, sugeria alguns artistas... e isso parecia funcionar muito bem.

As milhares de estruturas de planejamento que aprendi pareciam ser muito burocráticas perto da organização da aula do Paulo.

Embora a proposta da pesquisa não seja a de avaliar a didática dos cursos livres, percebi que a didática de alguns desses espaços poderia 
também auxiliar no estudo da didática para o ensino formal. Por exemplo, a proposta do Collegio das Artes é bastante aberta, os cursos não possuem sequer uma duração exata: os alunos podem freqüentar 2 ou 15 meses um mesmo curso. Não existe nenhuma proposta de conteúdos ou objetivos no curso.

Também achei que a coordenadora e sócia da escola, Saleti Barreto de Abreu, falou muito tranqüilamente da artista Vera Martins, que não possuía diploma. Outro ponto importante foi apontado por ela: na sua opinião, os alunos de cursos livres se envolviam muito mais na aula do que os de uma graduação formal, onde às vezes, fazem o trabalho apenas por obrigação.

Devo confessar que o ambiente do Collegio das Artes era o que mais se aproximava da minha formação, Eu cheguei a invejar pessoas que estavam lá, pintando, num espaço legal. A minha linguagem era mais próxima desses alunos que referenciavam os mesmos espaços que eu conhecia, os mesmos artistas, e pareciam compartilhar dos mesmos sonhos que já tive um dia.

Alguns momentos da aula do Paulo Whitacker

A aluna perguntou para o Paulo:

- Paulo, tem alguém para eu pesquisar? Estou precisando pesquisar mais, e testar uma coisa diferente.

O Paulo sugeriu os artistas Soulage e o Franz Kline para a aluna. Logo depois o Paulo orientava outra aluna sobre a montagem do chassi, onde se compra o sarrafo, como cortar.

Achei interessante que ele também fornecia orientações bastante técnicas (diz-se na área: "cozinha do pintor") além das conceituais. Mais do que isso, não tinha uma orientação ligada ao consumo de materiais caros, pelo contrário, sugeria soluções que fossem boas e baratas. 


\section{As alunas :}

- $\quad$ Silvia: Eu liguei no dia 20 de setembro e marcamos a entrevista para segunda feira, dia 26 de setembro, às 18:00 horas. Ela se formou em Direito. Estudou culinária, para ser chefe de cozinha, quando morou em Boston. Neste período sempre procurava visitar os museus de Nova lorque.

- Sara: não conversei com ela

- $\quad$ M. Suely é formada em direito. Comentou do ócio criativo. Combinamos uma entrevista na quinta - feira dia 22 às 17:30hs.

- $\quad$ A Betina está em São Paulo mas é alagoana, morou em Recife durante um bom tempo. Estudou arquitetura na UNB. Comentou que a Arte sempre esteve presente na sua vida, mas que resolveu fazer o curso de pintura depois de ler o livro do Domenico de Massi sobre o lazer. Ela também comentou que sua psicóloga faz um curso de aquarela com um orientador que interpreta as emoções através dos desenhos.

\section{Fruto da Arte: dia 19 de setembro de 2005}

A dona dessa loja/ escola foi minha aluna no curso de Educação Artística da Faculdade Integrada de Guarulhos, o que facilitou o nosso contato, pois alguns proprietários de escolas privadas ficam muito desconfiados quando falo da pesquisa.

Dois meses antes, (em julho), eu visitei a escola para conversar com os professores e as alunas.

Na semana anterior, eu havia ligado para duas alunas marcando a entrevista. Quando cheguei na escola elas pareciam nem se lembrar. Senti que ficaram impactadas após terem visto a minha câmera de vídeo, e me receberam muito melhor do que da primeira vez. A melhor recepção também pode ter ocorrido por eu estar arrumada de modo mais formal (porque iria dar aula depois). 
Embora eu tenha inicialmente explicado o objetivo do trabalho para as alunas, elas voltaram a me perguntar várias vezes se eu faria um vídeo, ou sobre quem iria assistir aquelas imagens...

Eu entrevistei as duas alunas com quem havia me comunicado e entrevistei ainda outra - Nair - que se ofereceu voluntariamente para a entrevista.

Todas as três entrevistadas eram aposentadas, e foram muito gentis e dispostas comigo. A última entrevistada, Nair, começou a me contar vários detalhes da sua vida, (e eram muitos, pois ela tinha 71 anos!!!). Isso me angustiou um pouco, por conhecer tão proximamente uma história de vida tão diferente da minha, e por esgotar todas as fitas disponíveis. Decidi ser um pouco mais objetiva em relação às perguntas. Na realidade, eu teria que estar com um suprimento de fitas maior, fiz um cálculo errado.

Essa mesma aluna me entregou o seu cartão. Achei-a muito organizada, e a sua disposição em fazer um cartão me impressionou. Ainda notei que o seu cartão tem uma semelhança incrível com o cartão do Emip, seu professor de pintura.
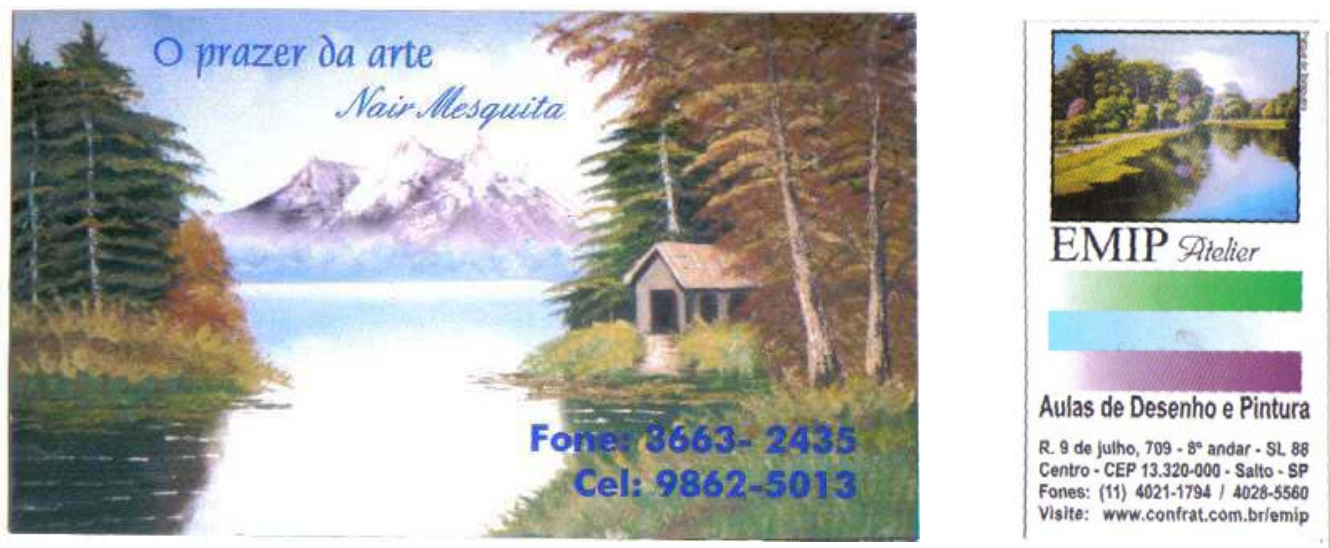

Cartão da Nair e Cartão do Emip, professor da Nair. 
Observei que todas as alunas do fruto da arte tiveram um cuidado especial com sua aparência antes da entrevista, (se maquiaram), o que me deixou muito feliz pelo valor que estavam dando à situação. O professor Emip também foi mais atencioso comigo nesta segunda visita, me entregou o seu cartão. Ofereceu-se para filmar e me disse que tem produzido muitos CDRoms com suas aulas de pintura: eu pensei em comprar um mas custava 120 reais, e meu orçamento mensal já estava no limite.

Existia certa homogeneidade no grupo: todos os alunos que vi no curso eram do sexo feminino, e a maioria (se não todas) possuía mais de 60 anos. Comentei com o professor Emip a grande quantidade de mulheres no curso, e ele respondeu (criando certa distinção entre a participação de homens e mulheres): "-As mulheres vêm aqui para fugir de casa, ou do marido. Quando um homem vem aqui, ele não quer fugir de nada.” Respondi com um educado sorriso amarelo. Isso era uma piada machista? Ou ele se referia ao fato de que para um homem , a decisão de pintar é muito mais séria , por se tratar de uma profissão artística, dita "feminina"?

\subsubsection{As alunas do Fruto da Arte:}

- Eunice: quando liguei para marcar uma entrevista ela se encontrava no velório da mãe. Fiquei muito sem graça. Não poderei nunca esquecer de antes mesmo de me identificar, perguntar se a pessoa pode falar no momento ou encontra-se ocupada.

- Francisca

- Célia: É a aluna que freqüenta o curso há mais tempo.

\section{Delta dia 26 de setembro de 2005: Visita à escola Delta}

Senti que essa escola era uma espécie de meio termo entre as duas escolas anteriores: as alunas não pintavam nem abstrações matéricas e nem 
paisagens bucólicas. Até visualmente a escola aparentava ser uma mescla de cubo branco com uma tradicional feira de pinturas.

Ela ocupa uma casa antiga. Na parte superior reside a dona e na parte inferior um equipado atelier de arte foi instalado.

A escola tinha um clima meio ZEN. Essa sensação foi criada por um conjunto: a dona me ofereceu um delicioso chá que era preparado por ela a partir de diferentes ervas, e sobre a mesa havia um livro "O poder do agora: um guia para a iluminação espiritual". Na parede um quadro em branco com uma frase do dia em relação ao fazer arte que era bastante espiritual e finalmente uma musica instrumental leve, daquelas que parecem servir para a meditação, soava no recinto.

Diferente das escolas anteriormente visitadas, esta escola oferece aos alunos módulos de aprendizagem, e depois uma proposta de ateliê livre onde os alunos poderiam fazer a sua proposta de trabalho. Ambas as donas são formadas pela Faculdade Santa Marcelina.

As donas comentaram comigo que atualmente estão oferecendo cursos de pintura para bancários e outras empresas. Elas se deslocam até estes locais para dar aula para os funcionários.

A primeira aluna que eu entrevistei era bancária de profissão mas já tinha feito curso de Educação Artística.

Na quinta feira seguinte combinei de entrevistar outros alunos, mas a aluna faltou e adiei a entrevista para mais alguns dias.

A aluna entrevistada: Cristina

Dia 30 de setembro de 2005: Entrevista com Eliane, dona do

\section{Fruto da Arte}

Gravei a entrevista com a Eliane. 


\section{Dia 13 de outubro de 2005: Mudança no roteiro das entrevistas}

Mudei uma parte importante da entrevista e espero que isso não anule as entrevistas realizadas até aqui. Coloquei como parâmetro algumas concepções de arte (mais gerais) apontadas no livro do Benedito Nunes. $O$ livro "filosofia da Arte" trata de questões essenciais sobre o que impulsiona o fazer artístico. Eu me surpreendi por não ter lido ele antes.

Recordei-me que no período em que decidi que deixaria de produzir arte, eu justamente não encontrava mais uma justificativa "racional" para essa prática. Ou seja, eu me colocava as questões da filosofia da arte, mas não tive acesso a uma boa discussão neste campo. Lembro-me de não encontrar uma justificativa para fazer arte: sem público, sem incentivo, com pouco dinheiro sempre. As pessoas fazem arte porque fazem, porque são artistas e artistas fazem arte: a pergunta sobre o porquê fazer arte parecia absurda para muitas pessoas da área. Só respostas demasiadamente românticas e crédulas circulam no meio.

Dia 17 de outubro de 2005: Aula de pintura e desenho de figura humana no Ateliê Kislansky

Hoje visitei o ateliê do Kislansky e me deparei com outra situação diferente. $O$ ateliê fica bem localizado, na Rua Teodoro Sampaio. Ocupando praticamente três andares de um prédio, onde se vêem salas de aula, forno e material apropriado para o aprendizado de escultura. Uma infra-estrutura que não havia visto sequer em Universidades de Arte como a Santa Marcelina, a Unesp e a Usp (visitadas durante o mestrado).

Embora a escola dele seja prioritariamente voltada para a escultura, eu assisti uma turma que fazia aula de desenho e pintura com foco na figura humana. A situação da aula me lembrou bastante as seções de modelo vivo propostas pelo Museu Lasar Segall nos anos 1980 e da Pinacoteca do Estado. 
E embora o meu interesse se concentre neste curso de desenho/pintura vale comentar um pouco os outros ambientes da escola que estão voltados à prática de escultura.

A escola me remeteu imediatamente aos ateliês dos escultores do final do século XIX, mais especificamente ao ateliê do Rodin, com aquela profusão de peças em processo de modelagem e várias modelos em poses clássicas no centro de estudantes.

Existe um trânsito muito interessante no ateliê: circulam lá alunos que fazem diferentes cursos como o de História da arte e palestras mensais com convidados.

Outra coisa curiosa é que o dono da escola mora no mesmo prédio, onde também residem o orientador de algumas oficinas e até uma das modelos. Isso dava um ar meio comunitário ao local, embora todas as relações fossem comercialmente tratadas. (achei assim ...)

\section{Dia 17 de outubro de 2005: Entrevista com Silvana}

Silvana (arqueologa) 43 anos

É interessante registrar que eu desenhei nas duas aulas que estava lá a convite do próprio professor Israel, já que eu tinha que chegar antes para entrevistar as alunas e esperar o término da aula para entrevistar depois.

\section{Dia 17 de outubro de 2005: Notas desiludidas sobre a} sobrevivência durante a pesquisa.

Hoje fiz uma projeção da quantidade de dinheiro que possuo e por quanto tempo poderei sobreviver com ele, já que optei por dar poucas aulas e estou gastando 1000 reais por mês a mais do que ganho com as aulas. $\mathrm{Na}$ projeção, eu tenho como sobreviver somente até junho do próximo ano. Fiquei pensando em quanto tempo dedico à pesquisa e se isso um dia valerá a 
pena. Isso porque fazer a pesquisa é muito caro, tenho me dedicado mais de 30 horas semanais, com a organização das entrevistas, material, deslocamento e tudo mais. Sem contar a dificuldade em ter que pensar somente no assunto, o sacrifício se torna enorme, por ainda abdicar de qualquer prática artística, e me limitar à pesquisa teórica.

\section{Dia 18 de outubro de 2005: Entrevista com Anna}

Anna (também é do núcleo de aquarelistas da Faculdade Santa Marcelina)

A entrevista com a Anna me pareceu ótima. Ela me trouxe novamente a questão que os cursos livres são mais práticos do que as faculdades. $\mathrm{Na}$ sua fala ela foi clara ao relacionar a arte como expressão pessoal, mas seu trabalho apresentava grande pesquisa da linguagem.

\section{Dia 20 de outubro de 2005: Entrevista com Silvia: Será isso o} imaginário Cultural?

Entrevista com a Silvia. É incrível como existe uma coincidência de gostos entre os alunos do Collegio das Artes e o meu gosto cultural. No dia que fui entrevistar a Silvia, por causa do atraso das donas da escola acabamos conversando assuntos diversos antes de iniciar a entrevista.

No seu carro, ela mostrou um CD produzido em parceria entre músicos da MPB e uma aldeia do Parque Nacional do Xingu, com participação do Caetano, Gil etc. Eu comentei de um amigo que tinha estado no parque trabalhando com educação indígena etc. Depois conversamos sobre tintas, sobre a possibilidade de comprar pigmentos, trabalhar com tempera ovo... ela comentou que iniciou aulas com o Marco Gianotti. Deste assunto partimos para o acabamento que ela estava projetando para a sua casa do sítio: acabamento com cimento queimado e pigmento, a possibilidade de decorar 
com pedras roladas, ou ainda piso hidráulico (meus acabamentos prediletos!!). Seria isso o imaginário cultural? O que faz com que eu e a Silvia tenhamos gostos coincidentes, sobre coisas tão diferenciadas?

\section{Dia 21 de outubro de 2005: Sobre a organização da Tese}

Hoje pensei em reescrever a tese numa ordem diferente. Por exemplo, achei que a organização por temas (os prospectos de propagandas, os cenários etc.) por um lado facilitava a leitura e análise destes, mas por outro lado desmembrava o assunto de tal maneira que perdia - se a noção de conjunto, e dificultava a aproximação da idéia de imaginário cultural de cada grupo. Talvez fosse melhor escolher algumas escolas e avaliar o conjunto delas ...o cenário, o prospecto, tudo junto. Desta forma a coincidente relação entre todos os elementos (que é o que tem mais me impressionado) fica mais evidente.

Dia 1 novembro de 2005: Entrevistas na Escola do Kislansky Marina

Neste dia eu havia marcado entrevista com a Cyntia, mas ela esqueceu. Acabei por entrevistar a Marina. Sua entrevista foi interessante por mostrar um interesse diverso no curso: o de aperfeiçoar a sua técnica profissional de animadora de desenhos.

Como eu tinha que esperar os alunos, porque fazia as entrevistas antes e após as aulas, ele me convidou para desenhar, caso eu quisesse, o que seria mais confortável para todos. 


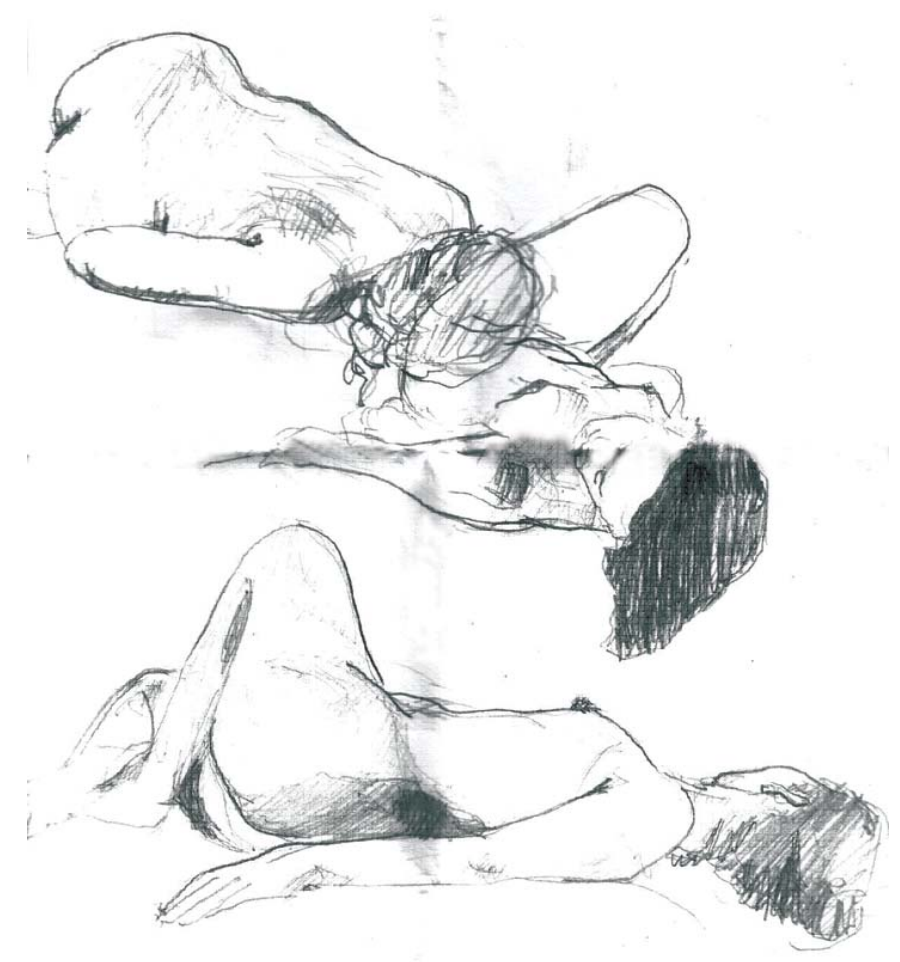

Desenho feito no ateliê do Kislansky.

\section{Cyntia}

entrevista Segunda feira antes da aula (16 horas horas)

A Cyntia é um caso curioso, porque após relatar sua trajetória que incluía graduação em licenciatura Educação Artística na FAAP, curso no MUBE, cursos na Itália e acompanhamento particular com artistas ela me indagou sobre a sua necessidade de estar lá. Isso me fez pensar que as entrevistas colocam questões novas para os entrevistados.

\section{Dia 25 de outubro de 2005: Ateliê Teresa Viana}

Este curso acontece no ateliê da própria artista: Teresa Viana. Eu a encontrei no Collegio das Artes, onde ela também está iniciando um projeto para dar aulas para crianças. Teresa também fez parte do quadro de 
professores do MUBE e já deu aula no Espaço Virgílio. Atualmente ela dá aula no SESC. O que leva a pensar que os cursos livres são uma fonte de renda para muitos artistas.

A situação deste curso é diferente, pelo fato de que o espaço do ateliê coloca as alunas ( 3 atualmente) dentro de um espaço de produção, em contato com o processo da artista. $O$ ateliê de Teresa é um espaço privilegiado, o espaço ideal para todo artista contemporâneo: um grande galpão, suas telas enormes encostadas em praticamente todas as paredes, uma iluminação natural. Cheiro de tinta óleo. Como espaço educativo também me pareceu um dos mais ricos que visitei. Lá estão permanentemente expostos os processos da artista. Suas dúvidas, seus desenhos, pinturas mais antigas e mais recentes e obras que estão sendo embaladas. Sem palavras.

As alunas dentro do ateliê podem ver a artista em processo, ver desenhos inacabados, idéias em suspensão, seus catálogos, obras embaladas, e tudo mais que um atelier de pintor pode oferecer. Esta situação já me pareceu muito rica e educativa. Embora a artista Teresa tenha apontado o perigo que sua obra poderia exercer sobre as alunas, penso que nenhuma delas estava fazendo nada parecido, e em algumas aulas Teresa prepara o espaço instalando mesas (bancadas sobre cavaletes e cobrindo suas telas).

Por sorte de que a Teresa trabalhou comigo há de 10 anos atrás, como monitora na Bienal Internacional de São Paulo, não sei se por isso, ela foi muito atenciosa comigo. Particularmente, eu gostei muito do trabalho que ela estava desenvolvendo e acabamos conversando bastante sobre o seu processo de trabalho e também a atual situação de mercado.

Muito interessante notar como que uma conversa como esta só poderia emergir num contexto como o de um atelier, pois mesmo nas outras escolas, a conversa com artistas/professores abordavam outras questões, mais relacionadas ao ensino etc. Parece, neste sentido que a artista por 
estar dentro do seu espaço de trabalho cumpre seu papel mais definido de artista e, mesmo sendo professora esse papel permanece sobreposto ao de professor.

É difícil estar num local como esse sem tematizar as questões intrínsecas ao trabalho da artista.

A artista me apresentou para suas alunas e eu marquei de entrevistálas na próxima quinta onde haveria uma aula de reposição.

Dia 27 de outubro de 2005: ateliê Teresa Viana, as melhores entrevistas até agora.

Até então estas foram as melhores entrevistas que consegui. Talvez pelo ambiente bastante tranqüilo e acolhedor, ou não sei...preciso pensar.

De todas as entrevistas até o momento, nestas eu estava mais acanhada (meu corpo inclusive até ficou tenso durante as entrevistas), mas por outro lado, notei que estava mais inquiridora.

Só hoje me dei conta como é grande a quantidade de egressos de cursos universitários - e artes plásticas - que fazem cursos livres . Duas alunas da Teresa, duas alunas do Israel, uma do Delta: incrível , eu não esperava encontrar isso.

Então refleti em como nos cursos livres se realiza um acompanhamento e orientação mais individual, que não acontece na graduação de arte . No ateliê da Teresa por exemplo, as alunas estavam trabalhando técnicas diferentes, começaram a freqüentar o curso em tempos diferentes, cada uma no seu ritmo.

Parece que o programa pré estabelecido acaba sistematizando por um lado, e por outro, acaba não permitindo uma pesquisa mais pessoal.

\section{Alunas entrevistadas :}

IA :Terapeuta Educacional 
Mariana: Formada em Artes Plásticas e proprietária de uma

Matilde: Formada em Ciências Sociais e Artes Plásticas

Dia $1^{\circ}$ de novembro de 2005: conversa com Jaqueline Aronis pelo telefone

Hoje falei com Jaqueline Aronis pelo telefone e ela me recebeu muito bem. Mostrou-se muito interessada na pesquisa e comentou que gostaria de saber mais sobre como funcionava outros cursos livres.

Depois de conversa com ela pensei sobre a nomeação "curso de pintura". Isso porque, quando perguntei sobre se ela dava aulas de pintura, ela me respondeu: - não é bem pintura, tem também pintura, mas nós trabalhamos muito com desenho (...). Mais adiante, ela explicou que se nomeasse o curso como pintura, "as pessoas associariam a um tipo mais tradicional de pintura e a pintura à óleo".

Sabemos que contemporaneamente essas divisões entre as técnicas são bastante limitadas, por isso resolvi incluir o curso da Jaqueline na pesquisa. Em conseqüência disso pensei sobre o recorte "cursos de pintura" da pesquisa e como ele expressa uma concepção de arte- que respeita essas divisões técnicas. Os cursos livres de pintura poderiam continuar como um eixo central, mas com certa flexibilização. Poderia ser transformado em: diferentes modos de fazer arte em torno dos cursos livres de pintura na cidade de São Paulo"

4 de novembro de 2005: conversa pelo telefone com Mariana.

Hoje tive uma das conversas mais difíceis pelo telefone com essa professora e artista, que dá aula de pintura no seu próprio atelier e também de arte contemporânea no MUBE.

A dificuldade se iniciou porque ela recusou a possibilidade de eu 
entrevistar a sua única aluna, uma senhora.

Comentou do cuidado que se deve ter ao falar que uma pessoa está fazendo arte, porque hoje todo mundo acha que é ator, pintor "quando na verdade não é nada". Que para ela o artista tem que ter consciência da história da arte, etc, me disse ainda da diferença que existe entre arte e artesanato.

Tentei explicar à ela que eu estava interessada em diferentes práticas relacionadas à arte, que não necessariamente compartilhavam desta mesma concepção de arte. Acrescentei ainda que estava inclusive mais interessada em estudantes do que em profissionais.

Foi interessante essa conversa porque ela expressou opiniões semelhantes 'as minhas num passado recente. Ouvi-la foi uma ótima maneira de avaliar como eu havia estendido a minha compreensão sobre o fazer arte.

Mariana foi muito atenciosa comigo, e contornou o seu receio em permitir a entrevista com a sua aluna ( no final disse-me que conversaria com ela na próxima segunda- feira) me dando dicas de muitos outros artistas que pareciam dar aulas nos seus ateliês.

\section{Dia 7 de novembro de 2005: Instituto Cultural Tomie Othake}

Hoje visitei o curso de pintura básico oferecido pelo Instituto Tomie Othake. Este curso é ministrado pelo Fernando Vilela que é formado pela UNICAMP. Acabei assistindo a aula onde o professor apresentou os seus trabalhos. Adorei ver os trabalhos do Fernando: ele mostrou umas xilogravuras para Site Specific, que são aplicadas diretamente na parede, interagem com a arquitetura local, promovem um respiro, uma espécie de vácuo no espaço. Lindas . Também fiquei impressionada em como os alunos responderam bem ao trabalho, que parecia bastante complexo. A turma misturava estudantes com profissionais liberais e empresários. Eu conversei com um veterinário, uma arquiteta , uma musicista, e uma professora de história da Arte (com 
formação em história ).

Choveu muito. Voltei de carona com as alunas Katia e a Ana Paula. Eu e a Ana Paula conversamos um pouco sobre as dificuldades de viver de aulas e sustentar a própria pesquisa, pois ela é professora universitária como eu, leciona história da arte no Mackenzie.

\section{Eu entrevistei:}

Marcos (veterinário)

O Marcos foi muito tranqüilo, lamentei que a entrevista tivesse que ser muito rápida por conta do início da aula. Mas o que mais marcou na entrevista dele foram as diversas e interessantes atividades que ele tem. A entrevista com a juíza aposentada do Collegio das Artes, também relatou esse mesmo leque de atividades, como a biodança e a fotografia.

Katia : embora seja cravista , não considera- se uma artista - ainda.

Ela é agitada e irrequieta. Na entrevista dela me dei conta de como a minha pergunta sobre o porquê elas faziam curso de arte, ou qual a função que a arte têm nas suas vidas, convida a uma reflexão e não à uma resposta. No caso dela, por exemplo, ela queria que eu enviasse o seu relato para ela, pois disse ter dito coisas que nunca havia pensado antes.

Falta combinar entrevistas com:

Sônia

Ana Paula ( professora mackenzie )

\section{Dia 8 de Novembro de 2005: Associação Parkinson}

Conversei com Lucy da Associação Parkinson, e ela me convidou para visitar o curso na próxima quinta feira, as 13:30hs. Combinamos que eu não entrevistaria ninguém neste dia , mas apenas iria para conhecer o curso e me apresentar. Ela me disse que os alunos pagam somente a mensalidade 
da associação e não pagam nada pelo curso. Também explicou que os materiais são comprados com o dinheiro ganho da venda das pinturas na exposição anual. Acrescentou que os alunos que freqüentam o curso não estão em um estágio muito grave da doença, existem muitos alunos que faltam, mas os resultados são muito bonitos.

Também Liguei para a OPA (atual Galeria Mali Vilas Boas) e fiquei sabendo, pela responsável pelos cursos, que agora eles só trabalham com cursos teóricos, não mais com cursos práticos.

\section{Dia 9 de novembro de 2005: Visita ao Cultural Blue Life}

Os alunos faltaram . Eu gravei uma entrevista com o professor Marcos Rossi. Ele me convidou para entrevistar, a noite, seus alunos do atelier.

\section{Dia 9 de novembro de 2005: Atelier Marcos Rossi}

O espaço do atelier do Marcos Rossi é diferente de todos os outros visitados. Marcos, que também dá aula no Espaço Cultural Blue Life, é graduado em Direito e após fazer aulas com um pintor que atualmente mora em Nova York, decidiu se dedicar exclusivamente à pintura. Marcos tem pouco mais de cinqüenta anos e pelas conversas que vi dele com seus alunos, trabalha também com tarô e reike.

Ele separa seus alunos em dois grupos: as senhoras do período vespertino e os profissionais liberais que trabalham mais a noite.

Seu ateliê situa-se no apartamento onde ele reside no Jardim Paulista. Em uma sala de mais ou menos 25 metros quadrados transitavam os cinco alunos (dentre eles um bolsista), vários cavaletes, telas, e mais 11 gatos, que miavam, ronronavam, pulavam e brincavam entre si e com os visitantes. Nesta mesma sala encontram-se umas pastas de figuras (referências de imagens). Sobre as mesas alguns livros esotéricos e espíritas. Nas paredes 
muitos retratos pintados, de negros, índias, mulheres árabes, retratos sob encomendas etc. O chão da sala é de piso frio, azulejo, onde várias tigelas com ração para gatos disputam o espaço com os bancos de plástico.

O espaço é insólito. Um pouco surrealista, pela mistura de gatos , cavaletes, arquivos de plástico.

Mais uma vez me espantei como a cidade de São Paulo pode esconder espaços culturais tão diferentes.

Esse grupo de alunos é muito fiel ao professor, possuem uma relação muito amistosa e parecem aprender muito através das conversas que têm com ele. Marcos é um educador que parece ingênuo num primeiro momento, mas tem uma ótima percepção das expectativas de seus alunos, e tecnicamente eles parecem dominar alguns elementos da pintura ( pude notar isso no vocabulário que empregam).

Um dos alunos entrevistados, o Geraldo, é bolsista e está por incentivo do Marcos se inscrevendo para um vestibular de Educação Artística. Este aluno mora no bairro Casa Verde (muito distante da escola) e este curso para o aluno Geraldo tem um papel importante na sua vida, em termos profissionais.

Olhar aquele grupo conversando sobre pinturas, sobre artistas foi uma experiência atípica para mim. O único problema que tive foi que um dos gatos se aninhou sobre a minha bolsa , e ao retirá-lo, ele soltou muitos pêlos sobre mim, tive uma reação alérgica que deixou meus olhos muito irritados e início de asma. Quando as entrevistas acabaram eu já estava no limite da minha resistência. Alunos:

Beatriz:

Paulo H. P.

Thema S.

Geraldo A. L. 


\section{Dia 10 de novembro de 2005: Associação Parkinson}

Quando entrei na sala da Associação Brasileira de Parkinson, já estavam algumas voluntárias arrumando duas mesas enormes de trabalho $e$ já se encontravam trabalhando algumas pessoas. Depois chegaram mais e mais ( ao todo 39 alunos). Muitos, se não a maioria, pareciam ter idade avançada e certa dificuldade para segurar o pincel sem tremer.

Os primeiros minutos que estive na Associação pensei que iria chorar, alías fui no banheiro e tratei de enxugar as lágrimas para não dar vexame.

Não sei , não consigo identificar a origem da minha emoção. Porque isto acontece? Porque nós nos emocionamos de ver um monte de pessoas com alguma dificuldade física? Foi o esforço deles que me emocionou? A dificuldade? A idade? A velhice? A superação da dificuldade?

A organização no local é fabulosa. Os alunos se sentam em torno das mesas e uma equipe de voluntários leva o material pedido: tinta óleo e tela ou então papel e guache. Eu mesma auxiliei neste trabalho. Ao fundo, uma animada musica popular da Austrália (Um CD de World Music da revista Caras). A sala era iluminada e o ambiente alegre.

\section{Dia 14 de novembro de 2005: Atelier Eva Soares.}

Nossa! É incrível como a comunicação tem um poder mágico sobre nós . Conheci o atelier da Eva Soares através da Internet e, pela quantidade de e-mails e avisos no site, pensei se tratar de uma escola enorme. Também estava quase certa de que a Eva Soares fosse uma mulher meio arrogante, $\mathrm{e}$ loira (não sei explicar o motivo, mas construí essa imagem). Qual não foi a minha surpresa ao encontrar lá uma mulher simpática, jovem, negra e que dava aula no seu modesto apartamento, que mobiliou sua sala de estar com cavaletes e um complexo equipamento de divulgação via internet. No dia em 
que lá estive era uma segunda feira, véspera de feriado, motivo pelo qual muitas alunas faltaram. Também em conseqüência do feriado as três filhas de Eva (de 2,3e 4 anos) estavam a circular no apartamento, dando um ar bastante familiar ao ambiente. A aluna que entrevistei chamava-se Sonia.

\section{Dia 14 de novembro: sobre alunos bolsistas}

Sonia, a aluna da Eva Soares, assim como o Geraldo da escola do Marcos Rossi, era também bolsista. Não é estranho encontrar nestes espaços, que eu pensava serem totalmente comerciais, alunos bolsistas? O que é raro encontrar até em grandes instituições como Faculdades e Universidades? Parece que a dimensão "pouco industrial" no que diz respeito a dimensão e a divisão do trabalho, acaba por tornar esses espaços mais pessoais e humanos , dando esse tipo de abertura e facilidade. O Geraldo, por exemplo tinha pedido um ano bolsa para a ABRA, uma escola grande de arte e não obteve resposta.

\section{Dia 14 de novembro de 2005 : sorvete com Espirito Santo}

Voltando da Escola da Eva Soares eu encontrei casualmente na sorveteria Soroko da Rua Augusta, o Rubens Espírito Santo (da Universidade Livre de Arte) e falei que estava chegando o momento de entrevistar os alunos dele. É sempre bom conversar com ele, sempre trocamos algumas idéias sobre nossos estudos.

\section{5 de novembro de 2005: A interação entre os sujeitos}

Uma das grandes vantagem de visitar estes locais e assistir as aulas é o fato de poder observar a interação do grupo. É claro que existe um jogo que define algumas atuações dos sujeitos no espaço. Suas representações nunca são totalmente individuais, mas fazem parte de uma interação. Pensei nisso após ler o livro “A representação do eu na vida cotidiana” (Erving Goffman) 
- indicação do orientador.

\section{6 de novembro de 2005: leituras}

É estranho ler o Pareyson hoje e me deparar logo na introdução, com uma discussão sobre se a estética se trata de uma ciência filosófica ou empírica.

Há quatro dias atrás eu escutei uma conversa (na verdade um rápido diálogo informal) entre o meu orientador e um outro professor o Lorenzo Mammi, sobre a minha pesquisa, conversa de corredor. E o meu orientador comentou algo sobre "essa coisa prática" que nós temos, que difere deles, que já que eles partem direto pra reflexão (...).

Essa fala criou uma pergunta que ficou ecoando na minha cabeça: Que reflexão é essa? Que não dialoga com o movimento e com as práticas da vida?

16 de novembro de 2005: o problema da tecnologia, como intermediária da pesquisa.

Achei importante relatar o problema que venho enfrentando por conta das gravações das entrevistas. Como fiz as gravações com a câmera digital, preciso achar um meio de poder assisti-las, só que para isso preciso pagar para que as imagens sejam transferidas para o $C D$, já que o meu computador não tem memória suficiente para suportar uma placa de vídeo.

Dia 17 de novembro de 2005: Parkinson

Alunos entrevistados:

Dioclesiano P. R.

José G. G.

José L. G. 
Nossa! Que dificuldade a minha. Nunca imaginei tal situação. Quando comecei a entrevistar o primeiro parkinsoniano já queria desistir. Os movimentos involuntários aumentam pela tensão causada pela câmera e pela situação de ser entrevistado. Isso dificultou muito a compreensão da fala. Percebi que a fala era afetada numa situação como a que eu estava propondo.

Dia 21 de novembro de 2005: Entrevistas no Ateliê da Jaqueline Aronis.

A Jaqueline havia sido muito atenciosa comigo ao telefone e também demonstrado muito interesse na pesquisa. No entanto, ao chegar ao seu atelier senti um pequeno receio por parte dela.

A professora me disse que os alunos não gostariam de ser filmados. Porque a primeira negação coletiva à filmagem? Nem pensei em questionar (mesmo que docilmente) essa decisão. A sensação que tive é que tenho que me contentar com qualquer coisa que lhe ofereçam, e isso já é muito. Muitas vezes eu me sentia como uma intrusa em espaços que eram privados.

Entrevistei a aluna Marisa com a câmera fechada. Mas o Otto, após ouvir que eu não usaria a filmagem sem pedir uma autorização prévia, disse não se importar com a filmagem. Mas, infelizmente, quando a Jaqueline olhou que eu estava filmando-o, senti que ela censurou um pouco o ato, o que me fez chegar à conclusão de que eles conversaram sobre algo anteriormente que os fizera chegar ao consenso de que a filmagem poderia ser prejudicial em algum sentido.

Também em um importante momento da entrevista onde eu questionei Otto sobre o porquê dele pintar, o que ele "ganhava" com aquela prática, ele respondeu que era porque podia conseguir arte e...como explicar o que era arte? Jaqueline interferiu dizendo que não precisava explicar. Puxa!!! Era justamente o que eu queria ouvir dele! 
Desta forma , as entrevistas no curso da Jaqueline aconteceram de forma um pouco em parceria com ela. Suas falas, no entanto, não deixavam espaço para muitos questionamentos. Nem fiquei a vontade para assistir a aula, e logo após as entrevistas me retirei.

Combinei de ir na próxima Segunda feira à tarde (14:00), ela me propos que eu fizesse então na segunda feira eu fizesse uma conversa coletiva(...)

Bem , fiquei pensando o que na minha atuação fez com que Jaqueline se sentisse pouco a vontade com a minha presença. Tentei inicialmente me mostrar bastante humilde, mas ao ver que isso não surtia efeito tentei me colocar de forma mais determinada... Sei lá. Na segunda feira chegarei mais cedo, para tentar conversar mais com ela sobre a pesquisa.

O atelier de Jaqueline é um espaço privilegiado, numa das regiões mais valorizadas de São Paulo, Higienópolis. Seu ateliê está ainda dentro de uma charmosa vila. Por dentro, seu atelier lembra uma galeria contemporânea, com móveis de design arrojado, predominantemente brancos. Simplesmente lindo.

Ela estava marcando com os alunos uma sexta feira para visitarem a exposição do James Ensor, que estaria acontecendo na FAAP.

Alunos:

Mariza Paoletti

Edson Otto Hahnemann

Dia 22 de novembro de 2005: Entrevistas com alunas do Espaço

\section{Cultural Blue Life}

A meiguice da professora ao lidar com as alunas foi o que mais chamou a atenção. Uma espécie de carinho que fazia até lembrar as escolas infantis ( $\mathrm{e}$ isso não é pejorativo). 
Um depoimento dela, na hora do café, me comoveu pela sinceridade e leveza com que ela encarava a arte, e pela coerência com que seu discurso respondia exatamente ao que as alunas procuravam e pensavam sobre o fazer arte. A professora disse que sempre comenta que a arte só traz coisas boas, porque dá prazer, serve como um adorável presente (que quem recebe jamais esquece), e ainda serve para pessoa ganhar uns "troquinhos" caso precise. Todas as alunas concordaram e foram muito claras ao expressar a função de lazer da arte, que faziam pra relaxar.

E também percebi, e isso já havia percebido antes, uma questão muito relacionada a função de dona de casa exercida pelas mulheres e como o curso de arte acaba sendo uma forma delas se sentirem valorizadas, ( percebi isso em duas alunas do Blue Life e também na aluna Sônia da Eva Soares).

Essa mesma função também pode ser relacionada com a função da arte na vida dos aposentados, que após encerrarem a sua vida profissional sentem necessidade de buscar algo que os valorizem novamente. Assim, pintar quadros torna-os talentosos em um período da vida onde são socialmente considerados improdutivos.

\section{Dia 26 de novembro de 2005: Entrevista com Fajardo}

Havia marcado uma reunião com o Carlos Fajardo, mas ao chegar na ECA, ele pediu que marcássemos uma nova data para que pudesse me dar mais atenção. Fiquei de ligar posteriormente.

\section{Dia 28 de novembro de 2005: Atelier Jaqueline Aronis}

Eu cheguei mais cedo no atelier da Jaqueline, e estava conversando com uma aluna quando ela chegou. Jaqueline Aronis chegou depois e disse que gostaria que eu não fizesse mais as entrevistas por que aquela era a última aula do mês e eu acabaria tomando tempo da aula. Ela esclareceu que 
gostaria de ter ligado para me avisar mas que não tinha o meu telefone. A aluna que estava conversando comigo até esboçou a idéia de me encontrar outro dia , mas eu achei incorreto fazê-lo.

Dei um sorriso constrangido, e disse que tudo bem, não haveria nenhum problema, mas acabei ficando chateada por ter ido até lá carregando a câmera, praticamente com a tarde toda perdida. Mas a sensação de estranhamento que tive na última visita foi confirmada . A Jaqueline, não sei exatamente a razão, desconfiou da minha presença. O que foi muito estranho já que ela se mostrou muito interessada na pesquisa na primeira conversa que tivemos ao telefone. $O$ que mudou entre a conversa pelo telefone e a minha visita? foi algo pessoal?

\section{Dia 29 de novembro de 2005: Convite para palestra na} Associação Parkinson

Ligaram- me da Associaçao Parkinson pedindo que eu participasse de uma conversa junto aos alunos.

\section{Dia 1 de dezembro de 2005: palestra}

Fui até a associação Parkinson, a convite da coordenadora do espaço Lucy, para participar de uma roda de conversa com os alunos em decorrência da exposição e do término das atividades neste semestre. Neste encontro, que era um encontro de encerramento das atividades anuais, muitos alunos deram o seu depoimento, dizendo como se sentiam bem nas aulas, de como muitos deles se sentiam felizes em observar os resultados finais. Eu também , como convidada, falei que fiquei admirada por ver tantos trabalhos interessantes. 


\section{Dia 16 de janeiro de 2006}

Sobre a leitura do Pareyson: A sua discussão sobre arte e vida se aproxima muito com as discussões da tese.

\section{Dia 17 de janeiro de 2006: transcrição das entrevistas}

Tenho feito a transcrição das entrevistas. A opção de gravá-las em vídeo me custou muito esforço, mas vejo que valeu a pena. A filmagem guarda muito bem determinadas emoções, a ponto de que tenho quase o mesmo esforço em assisti-las do que tive em fazê-las. Ao terminar de assistir e tabular uma entrevista quase não tenho mais energia para escrever. A fala da Anna, do ateliê do Kislansky, por exemplo, me ocupou uma tarde inteira.

AAnna ressalta que a arte na Universidade acaba por distanciar-se da prática de "fazer arte" por apresentar muitos questionamentos de natureza metalingüística. Puxa, não consigo deixar de invejá-la, já que eu sempre fui muito encantada com essa prática de ateliê, e que me distanciei dela justamente por ter-me colocado diante de muitos questionamentos.

\section{Dia 16 de fevereiro de 2006: funções da arte}

Hoje pensei algo muito importante para a pesquisa: a separação das categorias de funções da arte (arte como expressão, como fazer, como conhecimento) pode ser mantida porém, ao reler as falas, percebo que na maioria das vezes as pessoas misturam uma, duas ou três funções, o que é natural. O que ocorrerá, e que será diferente, é que algumas funções serão predominantes, ou seja, tenho que pensar mais sobre a organização do capitulo IV.

Dia 16 de fevereiro de 2006: Eu com os papéis das entrevistas Estava tão engraçado eu com os papeis das entrevistas na cama. 
Em pensar que tudo aquilo iria desaparecer. Pedi para ser fotografada trabalhando.

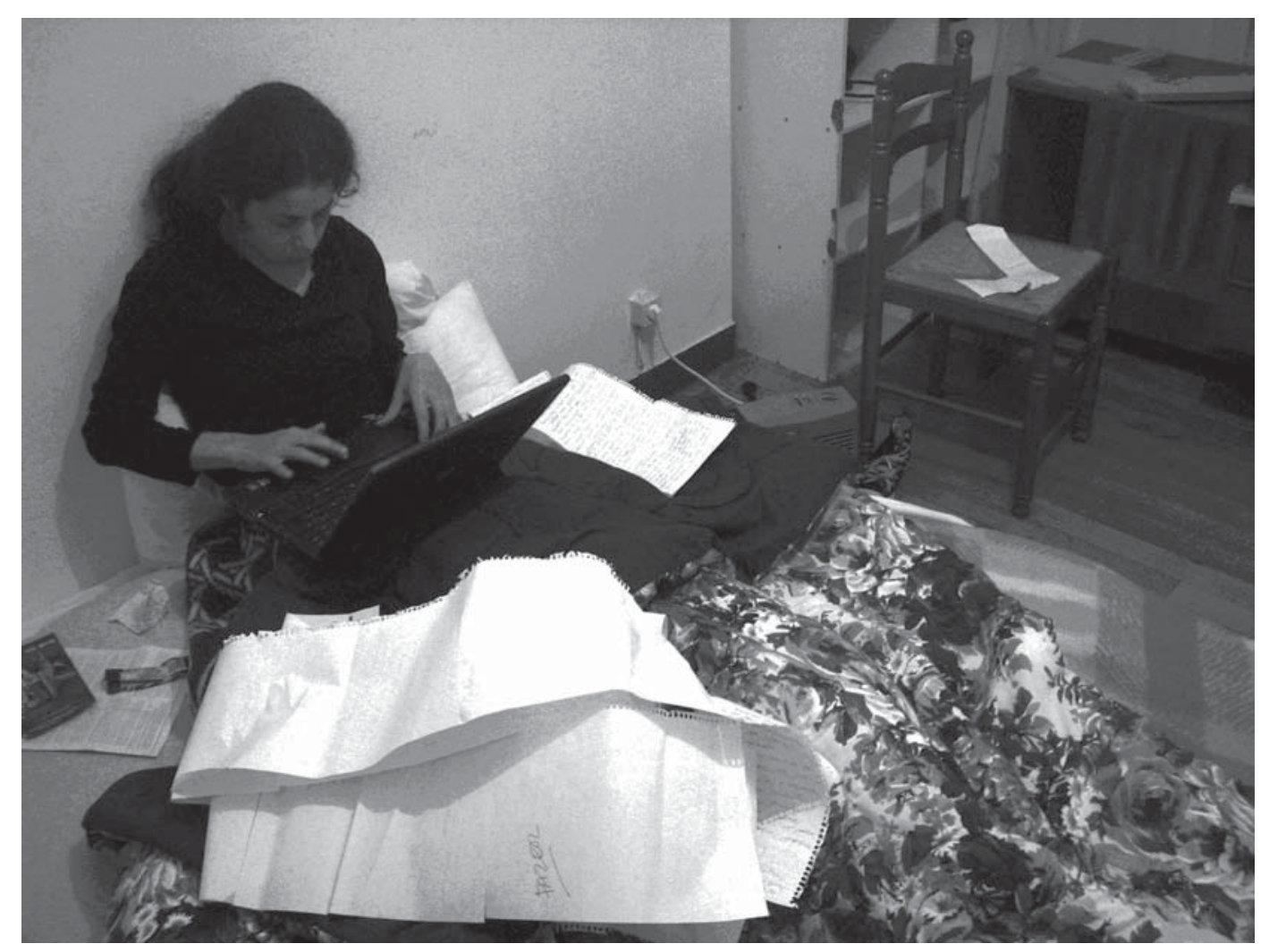

Digitando as transcrições das entrevistas, no quarto em La Coruña

\section{Dia 7 de Março de 2006; uma bolsa de estudos?}

Decidi que vou tentar pedir bolsa, e nem que seja por dois anos, já vale...Isso significa que vou ter que parar um pouco, para me organizar, e organizar toda aquela papelada da FAPESP.Como provavelmente vou ficar sem trabalho por uns três meses posso aproveitar para fazer isso. Essa decisão foi tomada porque estou me dando conta, que se eu permitir , o assunto pode ser discutido de forma bastante complexa, mas levará mais tempo, e mais dinheiro... ${ }^{1}$

A partir do livro do Bourdieu " Photography: A Midle -Braw Art" tive a 
idéia de misturar o gênero do ensaio com o argumentativo (mais cientifico), isso deixaria o texto da tese bem mais agradável.

Eu passei três meses em, La Coruña, Espanha, por conta própria. Pedi um afastamento sem remuneração das aulas da UNIFIG, já que a situação de lá não estava muito boa e também uma autorização para utilizar e emprestar livros na Universidade de La Coruña, ambos me foram concedidos. Aproveitei esses meses para transcrever todas as entrevistas e estudar mais o espanhol.

Resolvi que quando retornar ao Brasil, vou selecionar alguns dos livros "não ficção" que gosto e ver como estão organizadas as suas idéias, como os capítulos estão separando suas reflexões.

Penso que tudo o que possuo de tabelas, e até mapas pode ir para os anexos, não sei (...) ou talvez o mapa pudesse estar com mais contexto, e também as tabelas discutidas e apresentadas de forma mais "orgânica", já com alguma reflexão ao lado, ou na sua organização.

\section{Dia 10 de março de 2006: Leitura de Canclini}

Estava pensando, ao ler Canclini (Diferentes, Desiguales e Desconectados), que a pergunta central (Deus! Ainda estou questionando a pergunta central!) apresentada até então, tem resposta óbvia. É claro que existem múltiplas concepções e funções de arte nos cursos de pintura. $O$ que quero saber de verdade é: quais são estas funções e usos e se existe uma relação entre dominantes e dominados, se são grupos independentes ou ainda se existem trocas e questões comuns entre eles, ou seja, questões de interculturalidade.

\section{Dia 4 de abril : Organização geral dos capítulos}

Estou tentando reunir todo material escrito porque já tem mais de 
60 páginas. Por isso, pensei em organizar tudo como se já fosse para a qualificação. Olhando o capítulo de caracterização Geral pude ver que a lógica do geral ao específico está bonita e poderia manter essa organização. Como as coisas foram separadas para a discussão item por item, elas estão pouco relacionadas e isso me incomoda. O papel da conclusão final poderia ser o de justamente reunir esse geral com o específico. Aí sim poderiam aparecer as relações entre prospectos, espaços, práticas e concepções de arte.

\section{Dia 7 de abril : Curso de redação na Casa das Rosas}

Iniciei no último sábado um curso de escrita na Casa das Rosas com intuito de melhorar a redação da tese. Poder construir as minhas idéias em um texto mais poético. A intenção é poder exprimir as idéias de forma mais clara, porém com poesia, uma dose de imprecisão e aberturas para reflexão.

\section{Dia 17 de maio : Livro do Israel Kislansky}

Lendo o livro de autoria do Israel e do Ênio , fiquei impressionada com a clareza que possuem em relação a simultaneidade de diferentes pesquisas artísticas, ignoradas pela história e crítica de arte. Pensei a partir da leitura deste livro em alterar o título da tese. Seria

AMADORES DAARTE: formas contemporâneas de aprender e fazer pintura nos cursos livres de São Paulo?

\section{Dia 19 de maio : Encontro casual com o orientador na} lanchonete da FEUSP

Hoje encontrei casualmente o Favaretto na cantina da Faculdade, e achei que ele deu uma chamada de atenção, ele perguntou: Você existe 
ainda? Ai que "carão"! Eu tinha decidido entregar as coisas mais acabadas para não cansá- lo. Mas é difícil saber essa medida . Ele disse no início que leria tudo, as idéias soltas, por acabar, mas a verdade é que isso é inviável , porque os erros de redação acabam por atrapalhar a compreensão do texto. Acho que já entreguei textos mal escritos demais (...)

\section{Dia 19 de julho: Pedido de bolsa Santander/ Banespa}

Ao fazer a minha matrícula de acompanhamento, pela internet, vi na página da pós graduação um programa de mobilidade (estágios em Universidades Estrangeiras ) financiado pelo Santander/ Banespa.

Fiquei uma semana tentando encontrar algum professor, dentre as universidades estrangeiras listadas, que pudesse me enviar uma carta convite. Finalmente o professor Fernando Herández me enviou sua carta.

O Favaretto também , prontamente, escreveu uma carta de apresentação, que pedi em poucos dias antes do encerramento do prazo final de inscrição.

Pude observar o Favaretto elaborando a carta. E seu modo de escrever. Ele escolhe as palavras antes de digitá-las: não escreve e depois modifica muitas vezes. Ele faz poucas alterações depois que escreve, muito menores do que as que costumo fazer. Ele parece escrever no computador, como se o computador fosse uma máquina de escrever: como se cada erro fosse significar reescrever tudo novamente. Ele tem grande concentração para que o texto já fique pronto em poucas releituras, por exemplo. Seu sistema é mais denso, exige muita concentração, mas é mais rápido e preciso. Percebi que o computador não tem me ajudado muito a escrever e que em meio a tantos recortes e colagens, acabam surgindo milhares de problemas gramaticais, que pedem infinitas e exaustivas revisões. 


\section{Dia 20 de novembro de 2006}

Assistindo algumas aulas e participando de grupos de estudos aqui na Universidade de Barcelona, começo a problematizar, uma das questões colocadas na minha banca de qualificação: a ausência de reflexão sobre o método e sobre os instrumentos de pesquisa.

Bem, devo confessar que agora, tardiamente, me conscientizo de que a etnografia foi um método bastante presente, e que felizmente considerando a pouca reflexão feita- não teve erros graves de conduta.

Mas considerando, a tempo, algumas questões da etnografia contemporânea, devo refletir sobre a forma de apresentação da pesquisa e a utilização das fotos, que não podem ser consideradas - ingenuamente - provas etnográficas.

Também outro cuidado: evitar um tratamento demasiado global e homogêneo, deixar espaço para que se manifeste a polissemia.

A idéia de pensar a escritura da tese como um instrumento de comunicação já havia sido pensado, mas, com essas proposições da etnografia contemporânea, pode ser concretizado (e defendido) com maior eficácia.

\section{Dia 24 de dezembro de 2006}

Não posso esquecer de comentar a recepção das pessoas em relação a entrevista. Por exemplo, algumas pessoas interessadas, que pediam a entrevista por e mail, e outras que desconfiadas, se esquivavam de ser entrevistadas ou filmadas, simplesmente ficavam alegres em dar a entrevista.

\section{Dia 20 de dezembro de 2006}

Sobre El efecto de Las homologías de Bourdieu: Parece que a 
reflexão de Bourdieu nos ajuda a compreender que os cursos livres estão inseridos dentro de um mesmo campo: que precisa das distinções para sobreviver.

Isso era uma pergunta de muito tempo, desde o início da pesquisa existia essa dúvida: Como práticas diferentes podem pertencer a um mesmo campo? Sim, podem. No campo cultural, principalmente, a distinção com o vulgar - E ESSE VULGAR, ou diferente do DOCTO, DEVE EXISTIR- é fundamental.

Desde o principio queria descobrir qual era o lugar que ocupavam algumas dessas pessoas, que lugar era aquele da Praça da República? Da Rua Marques de Itú?

Dia 2 de janeiro de 2007: Os souvenirs de Museus de Arte

É claro que agora, eu e a pesquisadora dos amadores, somos inseparáveis. Assim que cada vez, esse diário vai se tornando cada vez mais um importante e oficial meio de registrar temas para novas pesquisas.

Por dois meses na Espanha venho fotografando os souvenirs de arte que são vendidos nas lojas do museu , um tema que não é distante da pesquisa, e que posteriormente gostaria de transformar num ensaio. Os souvenirs de arte são objetos que desapercebidamente - ou não- revelam uma série de contradições em relação a outras práticas do museu. Se, como afirma Bourdieu, os visitantes dos museus às vezes reproduzem comportamentos que reconhecem serem apropriados para aquele espaço, porém, ( penso eu), nas lojas de museus eles se expressam de forma natural e distinta dos espaços expositivos. Na loja dos museus esquecem suas representações de fruidores da arte e ... viram (...?) .

Essas lojinhas de museus se assemelham ao que Bourdieu chamaria de espaço entre o douto e o vulgar, ou ainda ao que Canclini chamaria de 
manifestação cultural hibrida.

Dentro dos arrojados espaços arquitetônicos oferecidos pelos museus, um design geralmente inovador caracteriza esses espaços. No entanto, essas lojas vendem objetos que preenchem quase todos os princípios do kitsch estudadas por Molles (inadequação, acumulação, mediocridade etc.)

O melhor de tudo é que às vezes tudo isso está etiquetado e embalado, ou ainda cunhado com o logotipo de museu , que parece atribuir a esses objetos uma marca de legitimidade. O mais interessante parece ser a transição do publico entre esses dois espaços de fruição dos objetos visuais.

Dia 8 de janeiro de 2007: observações do público de arte no

\section{Museu do Vaticano}

Não esquecer da pior experiência museológica: o Museu do Vaticano. Sem sentido algum, a visita ao Museu do Vaticano, assim como a visita a outros "grandes museus dos mundo" parece-me patética. A tristeza desta experiência não é conseqüente do acervo, mas sim de todo o ritual artificial, de toda a encenação de apreciação ao culto (cujo amuleto maior é a maquina de fotografia).

Por outro lado, irrita observar como o museu insiste em ignorar a encenação de um público que aprende pouco com a experiência de andar em fila (de quatro horas de espera fora do museu, e de fila andante por uma hora dentro do museu). Como o museu subestima seus visitantes com audio guides que de forma prolixa apenas reforça a magnitude daquela experiência vazia

Decidi fazer jejum de fotografias.

\section{Dia 20 de novembro de 2007: Monumento à pesquisa}

Espaços como a universidade, a biblioteca e outros freqüentados durante a vida acadêmica compõem o imaginário autoral de uma pesquisa e 
imprimem temperamento à investigação.

Quase todas as reuniões desta tese de doutorado foram feitas na casa do meu orientador, uma casa que remete à intelectualidade, ao intelectual, com tudo o que imaginamos sobre um lugar assim: uma parede inteira de livros, uma cuidadosa coleção de pinturas e gravuras. Sobre os móveis, cabeças de madeira ou curiosas formas selecionadas da arte popular, sofá confortável, mesas discretas, que, aqui e acolá, percebemos que carregam história. Difícil descrever na totalidade, mas poderíamos complementar esse cenário com a iluminação indireta, suave e eficiente de um abajur (não ao acaso, nesse caso uma palavra de origem francesa), e um gato, claro! Um gato velho (sumido nos últimos encontros) sempre deitado no sofá. Modelo de casa que eu, talvez inconscientemente, tente imitar, excetuando a presença felina, impossibilitada pela minha asma alérgica.

A experiência da pesquisa transcende então á pesquisa em si, ela é também a vida nesses lugares, a relação de pessoas com tempos tão diferentes como a de um orientador e uma orientanda que protagonizam - e agonizam - tudo, como, quando assisti a uma controlada irritação por ter impresso o trabalho em letras muito pequenas (para ser prática, economizar peso, papel e impressão), sem ter considerado a dificuldade de leitura do orientador.

Dessa significância toda, difícil de ser representada em palavras, preferi eleger um monumento: um quadro. Um dia, ao entrar no prédio do meu orientador dei de supetão com um quadro fixado na parede: era um antiquadro de uma casa de intelectual. A pintura representava um vaso de flor com uma borboleta dentro de uma janela e estava emoldurada inclusive entre duas abas de uma falsa janela: uma falsa janela imitando uma janela num quadro que imitava a vista da janela, enfim, dá para ter uma idéia [...]. Mas, estranho mesmo, era imaginar meu erudito orientador, crítico de arte, cotidianamente 
atravessando o hall do seu prédio e lidando com aquele objeto ordinário, sem relação alguma com a sua casa ou com a suas idéias sobre arte. Imaginei que era uma situação esquisita.

Hipoteticamente imaginei que a autora daquela pintura fosse uma de suas vizinhas, que ele comentara que fazia coisas parecidas com as que eu estava observando: ele pediu que eu não a entrevistasse, para evitar [...] não me lembro exatamente o quê. Inevitável. Dei-me conta de que a vizinhança do meu orientador, sua esposa de humor refinado e seu gato misteriosamente desaparecido ${ }^{2}$, ou sabe-se mais o que, invadiam e construíam todo o processo de investigação e que o trabalho da pesquisa não se limita apenas ao nosso objeto de estudo.

\section{Dia 8 de fevereiro}

Fazendo a revisão desse diário, para incluí-lo na tese, noto que ele parece ser desajustado ao universo acadêmico, porém reconheço que gosto da sua presença como anexo da tese, justamente porque sou afeiçoada pelas experiências, e pelos processos. Sei que isso parece um pouco "senso comum", mas aqui não foi diferente: embora desanimada com o "produto final" da tese, me sinto muito satisfeita em observar o todo o processo de feitura e reflexão da mesma.

\footnotetext{
Notas

${ }^{1}$ Meu orientador achou que a minha tese não estava madura para solicitar a bolsa Fapesp, assim que posteriormente, solicitei a bolsa Santander por 6 meses.

${ }^{2}$ Não tive coragem te perguntar, mas acho que o gato faleceu durante a orientação. Prestamos uma homenagem subterrânea a ele neste rodapé.
} 


\section{APÊNDICE B}

Tabela de entrevistas 
